\title{
الدلالات البلاغية لأسلوب التجاذب في السياق القرآني
}

\author{
الدكتور رمضان محمد عبدالغفار البدوي

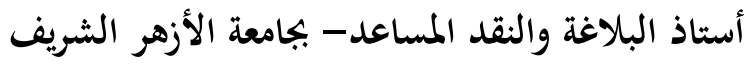




\section{اللقــــمــة}

الحمد لله حمداً يليق بجلاله وكماله وجماله ، وصلاة وسلاما على النبي الخاتم المعلم وعلى

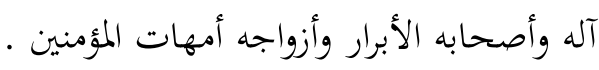

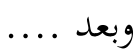

فأحسبني واحداً ممن يطيب له أن يتأمل القرآن ، ويتدبر مفرداته وتراكيبه ليفهم شيئا من

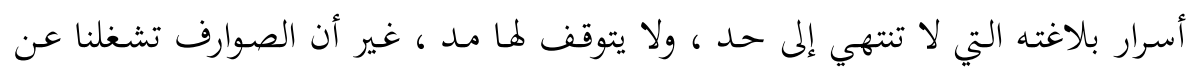

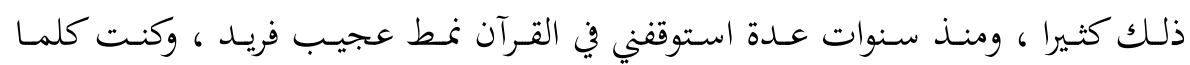

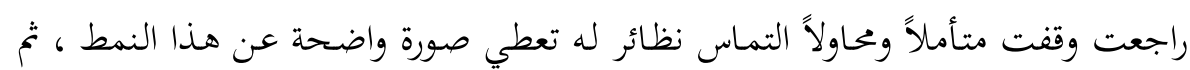

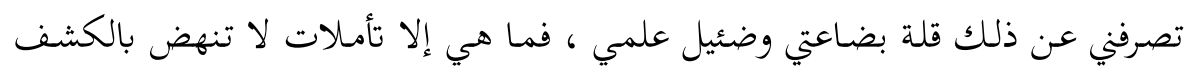

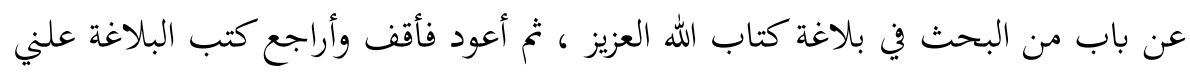

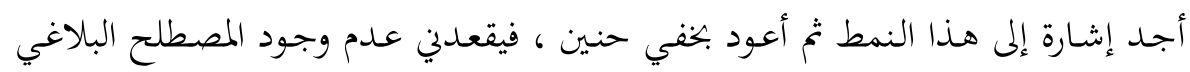
عن البحث في سر بلاغته ماأتأمله.

ما بعدها، انطلاقاً من فن الوقف والابتداء في الذكر الحكيم من جهة ، والتوجيه الإعرابي

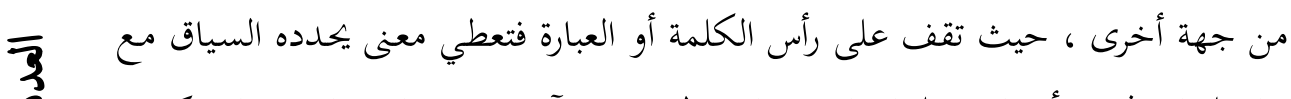

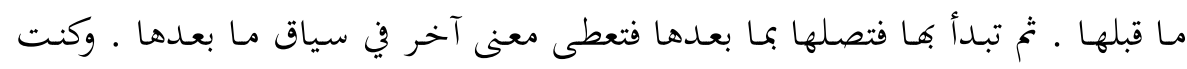

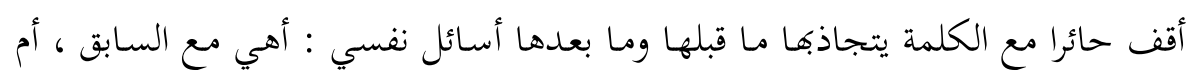

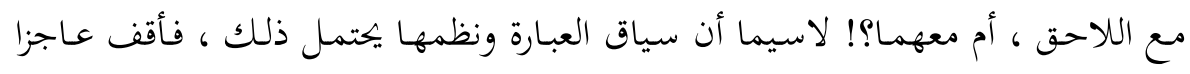

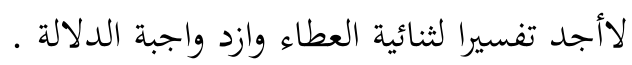
وبينما أنا على ذلك قادي بحث أعددته في سورة (يس) تحت عنوان : (أثر السياق في بيان قضية البعث والجزاء في سورة يس) ـ قادين هذا البحث ـ إلى هذا الحبئ الذي طالما

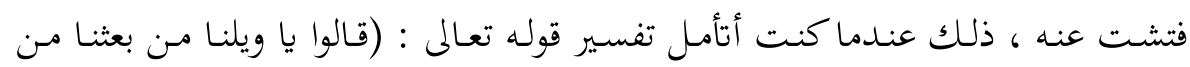

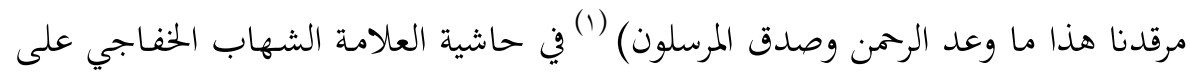

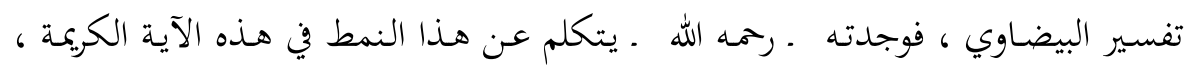
موضحاً أن اسم الإشارة (هذا) يعطي مع قبله ومع ما بعده ، و وإذا به يذكر هذا لهن المصطلح 
البلاغي ، ويكشف لي لأول مـرة عن هذا الخبئ ، ذلك في تعليقه على مـاذكره العلامـة

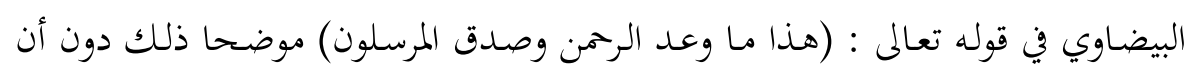

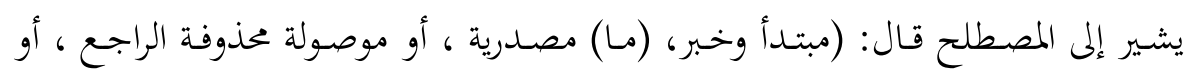

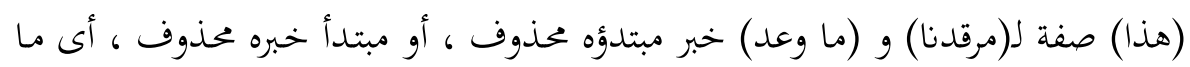

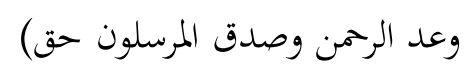

$$
\text { هذا كلام البيضاوي وقد ذكر في كلمة (هذا) وجهين : }
$$

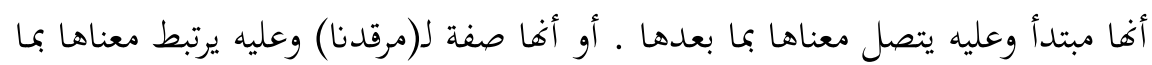

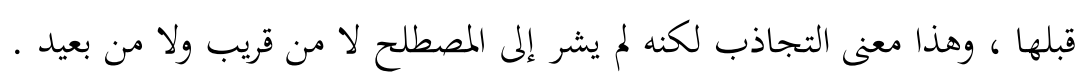

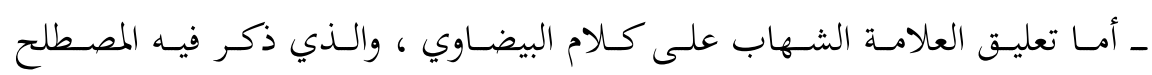
(التجاذب) فهذا نصه : (وفيه من البديع صفة تسمى (التجاذب) وهو : أن تكون كلمة

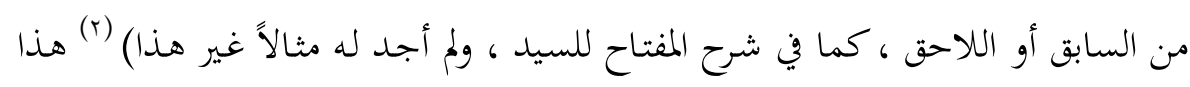

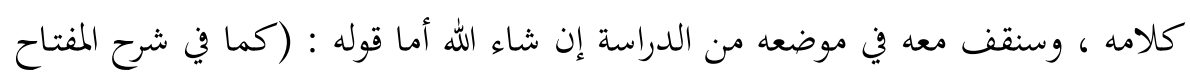

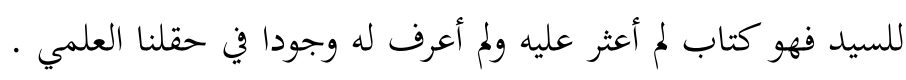

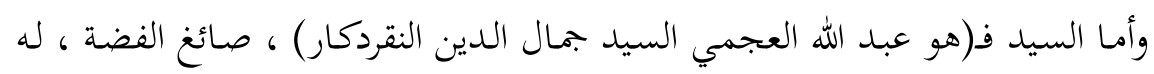

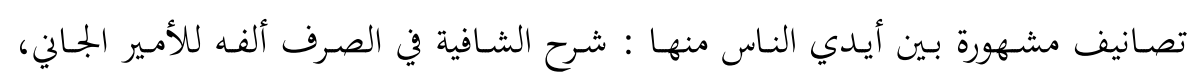
وشرح التلخيص ، وهو شرح مززوج بالمتن ألفه للأمير متكلى ، توفي سنة ( . . 1هـ) ثمانمائة

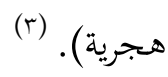
وأما قول الشهاب : (ولم أر له مثالاً غير هذا) فقول مـ لم يتتبع لأن غيره في القرآن

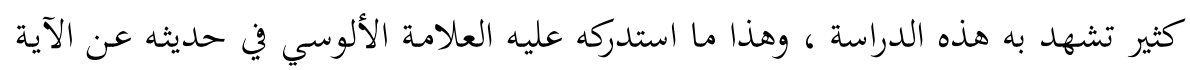
نفسها من سورة (يس) فقد ذكر بعض شواهده ، قال ـ رحمه الله ـ : (جملة من مبتدأ وخبر

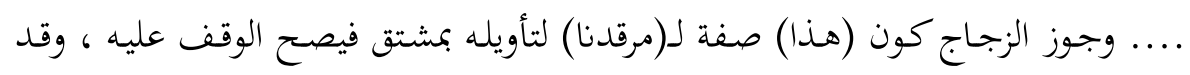

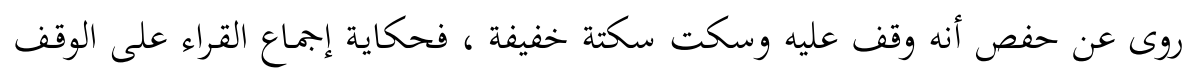

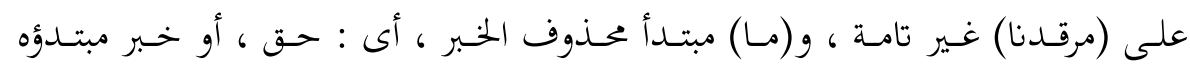

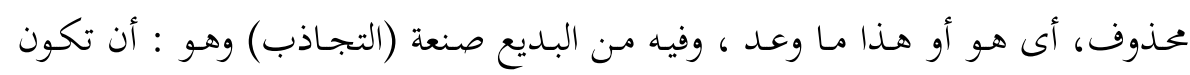

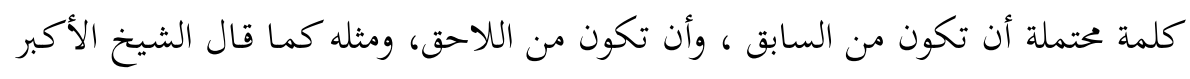


ـ قدس الله سره . في تفسيره المسمى بإيجاز البيان في الترجمة عن القرآن (؛)، ومن خطه

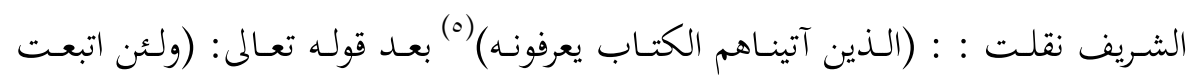

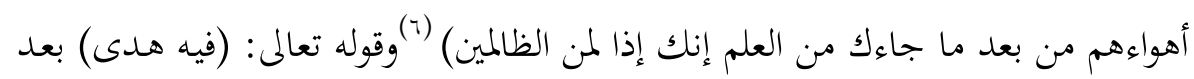

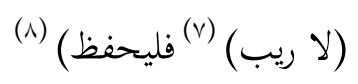
هكذا ذكر العلامة الألوسي أمثلة أخرى للتجاذب ، وذكر أنه نقل ذلك عن الشيخ

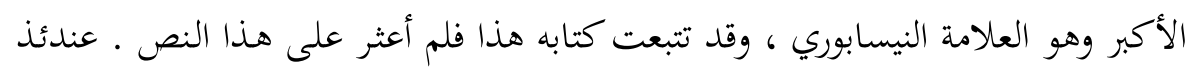

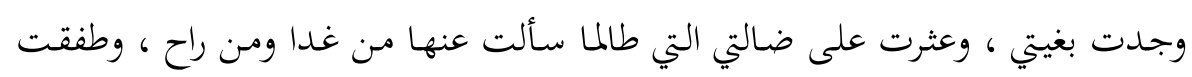

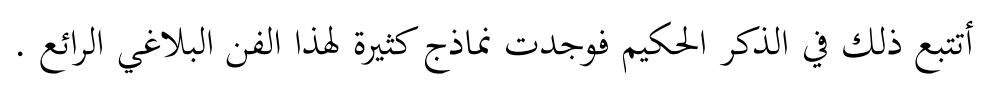

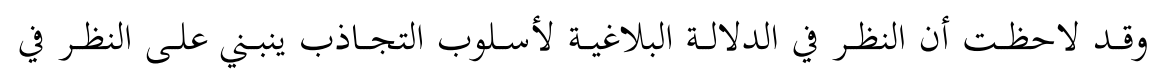
أمرين:

الأول التوجيه الإعرابي ، حيث إن اختلاف المعنى يتفرع عنه اختلاف الإعراب ، لذلك قالوا : الإعراب فرع المعنى . 91 الثاني : في الوقف والابتداء ، فعلى الوقف يعطي السياق دلالة ، وعلى الابتداء ، أو

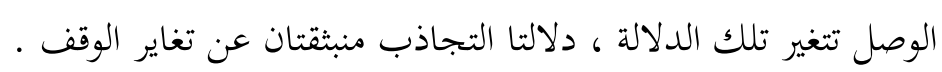

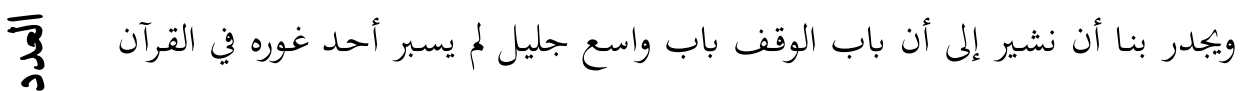

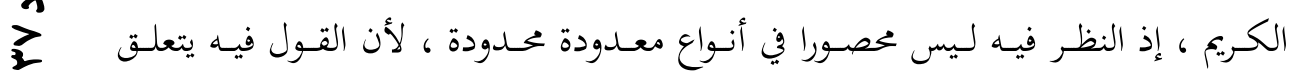

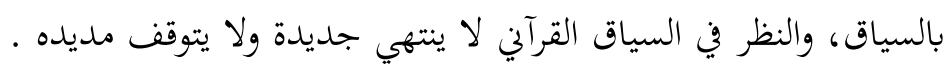

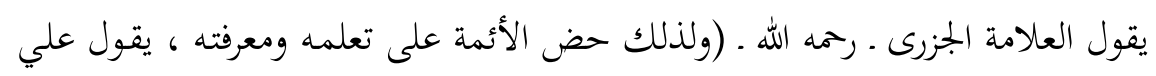

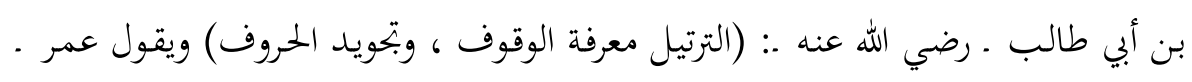

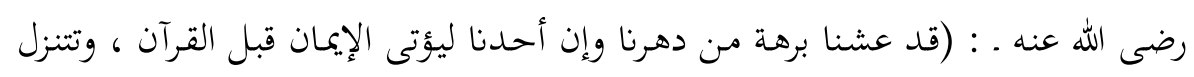

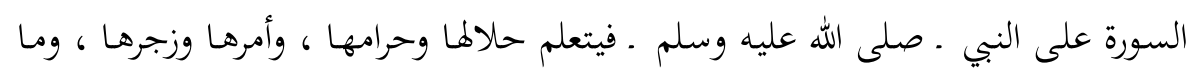

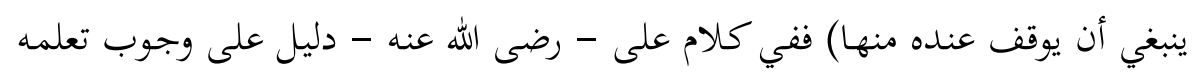

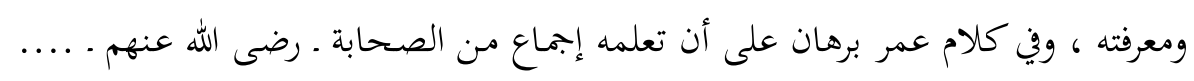

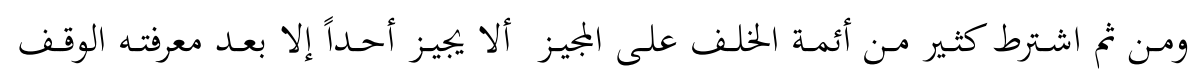

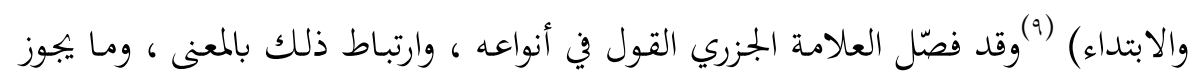


منه وما لا يجوز ، وصلة ذلك بالإعراب واختلاف المعنى باختلافه ـ ومن إشاراته إلى هذا النوع من الوقف الذي هو موضع دراستنا - وسمـاه المراقبة في الوقف - قوله وقد ذكر تنبيهات: (قد يجيزون الوقف على حرف ، ويجيز آخرون الوقف على آخر ، ويكون بونين

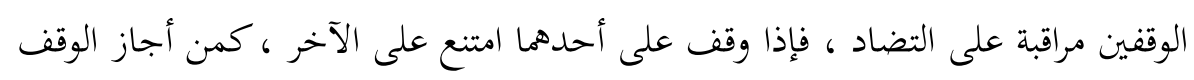

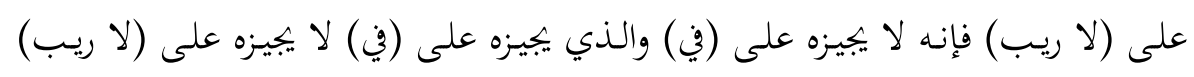

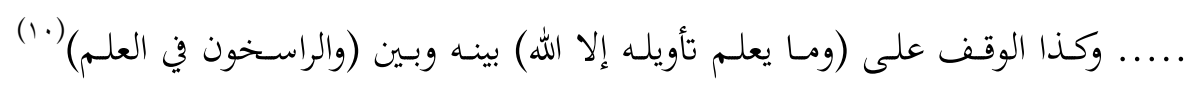
مراقبة، وكالوقف على (من النادمين) يراقب من أجل ذلك) (11)

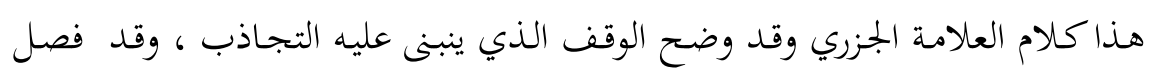

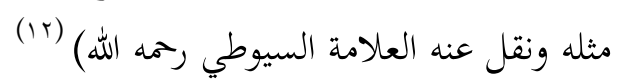
وبعد أن وضح لي ذلك شرعت في هذه الدراسة ، ولماكان محط النظر في بيان هذا لفها

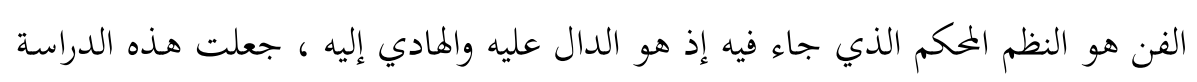

$$
\text { تحت عنوان (الدلالات البلاغية لأسلوب التجاذب في السياق القرآني) }
$$

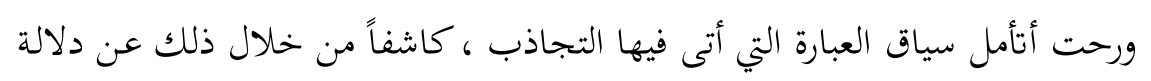

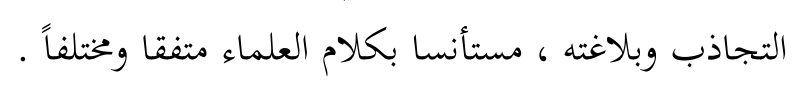
- وقد بدأت هذه الدراسة بمقدمة أوضحت فيها أهمية الموضوع والداعي إلى دراستها، وخطة السير فيه .

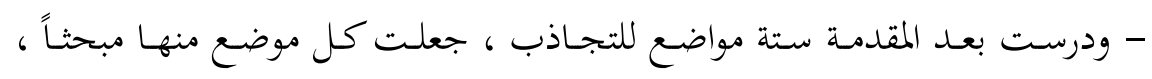
وجعلت كلمة ، .أو عبارة التجاذب عنوانا لكل مبحث من المباحث الستة .

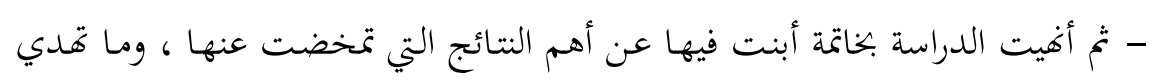

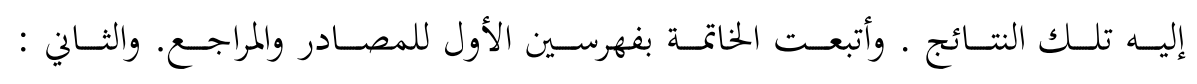

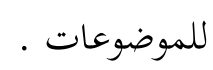
هذا ...و الله أسأل أن يجعل هذا العمل قربي إليه ، وخدمة لكتابه ، وعلماً ينتفع بـه ليكون لنا مدداً في عالم الغيب بعد انقطاع المدد من عالم الشهادة .آمين. 


\section{المبحث الأول :التجاذب في (هذا)}

قال تعالى : (ونفخ في الصور فإذا هم من الأحداث إلى ربهم ينسلون قالوا يا هاديا ويلنا من

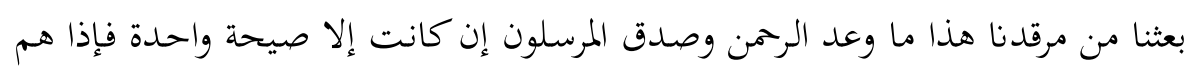

$$
\begin{aligned}
& \text { يس: 1.01.0 } \\
& \text { جميع لدينا محضرون) }
\end{aligned}
$$

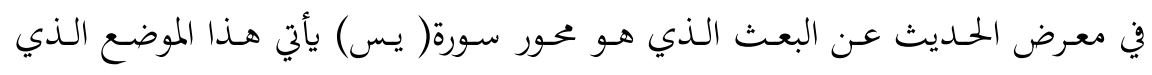

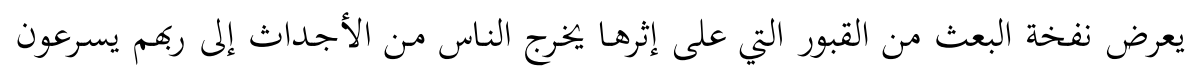

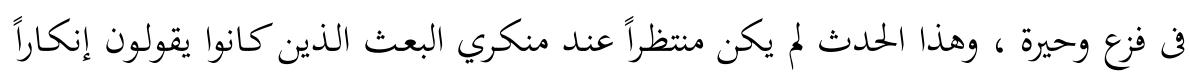

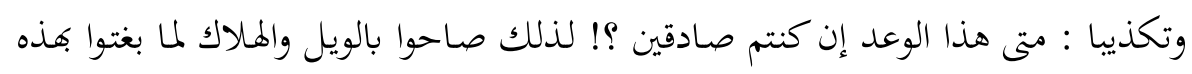

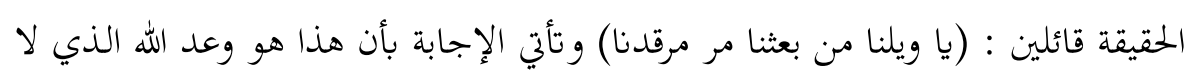

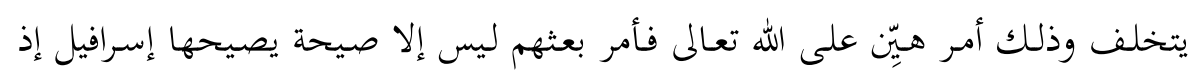
ينفخ في الصور (فإذا هم جميع لدينا مضرون) .

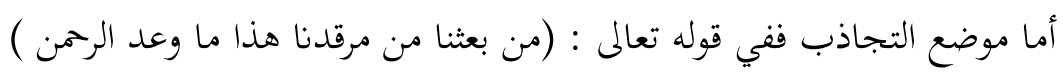

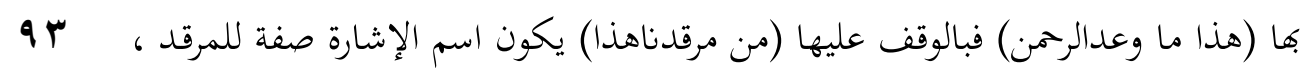

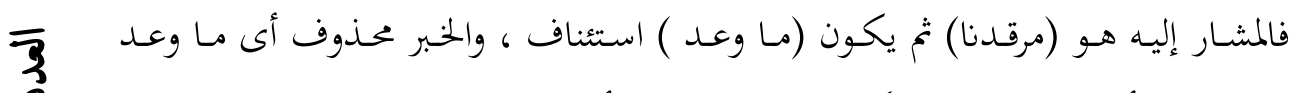

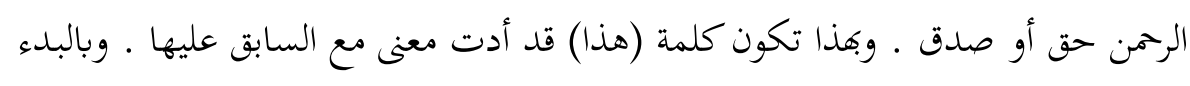

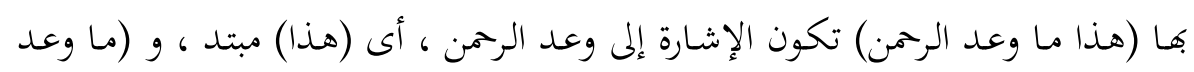

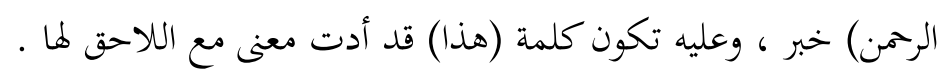

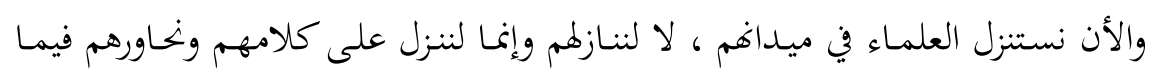
التبس علينا فهمه .

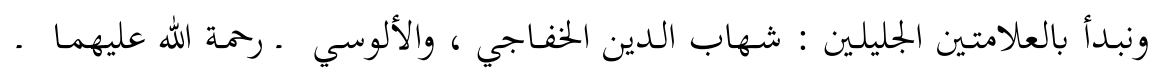

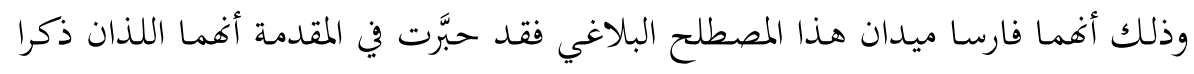

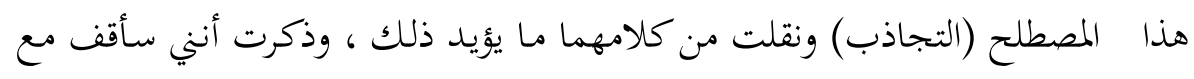

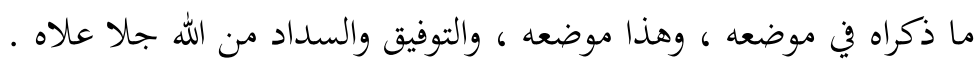




\section{العلامة الشهاب ومصطلح التجاذب .}

أما العلامة الشهاب ، فإن الوفاء لأهل الفضل يقتضي أن نذكر الأصل الذي حداب النهاه إلى كالى

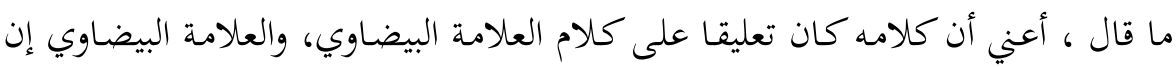
كان لم يذكر المصطلح فإنه ذكر التجاذب في العان العبارة الكريمة .

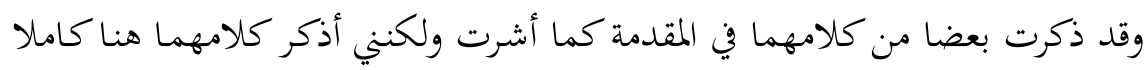

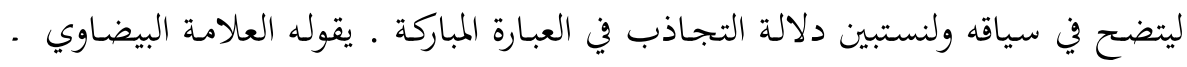

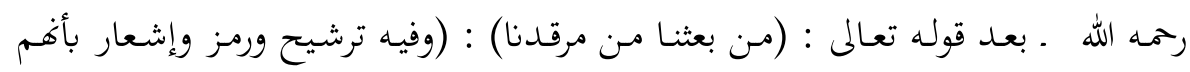

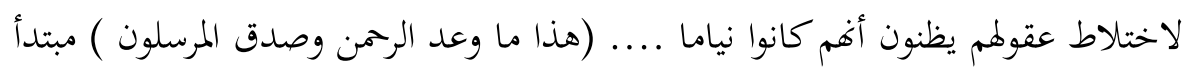

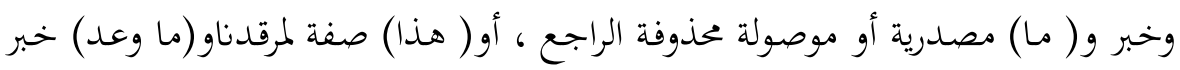

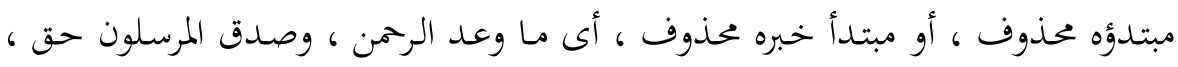

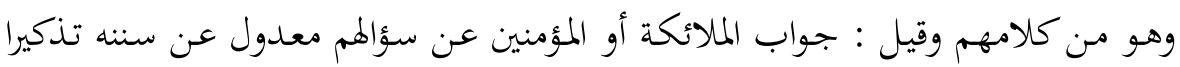

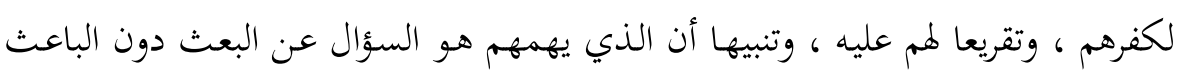

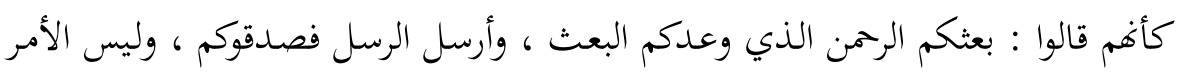

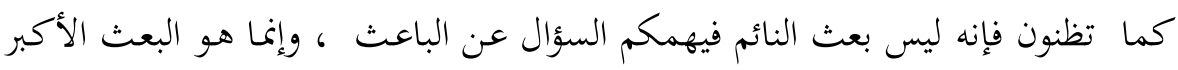

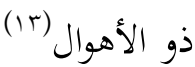
هذا كلام العلامة البيضاوي ـ رحمه الله ـ وقد ذكر أن القوم سألوا سؤال من يهذي وقد الفال

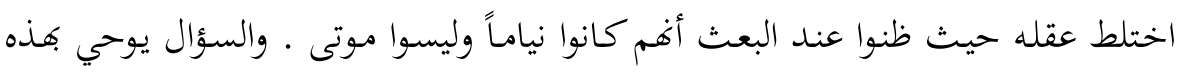

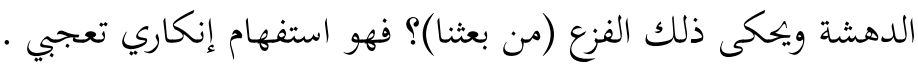

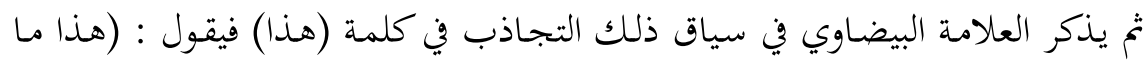

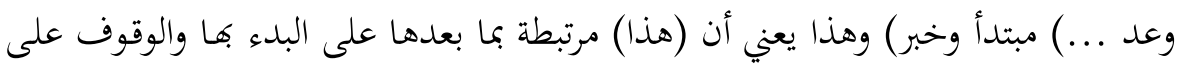

تم ذكر الوجه الثاني للتجاذب فقال: (أو هذا صفة لمرقدنا) وهذا يعني أن (هذا) تعطى

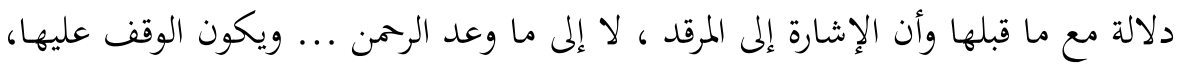

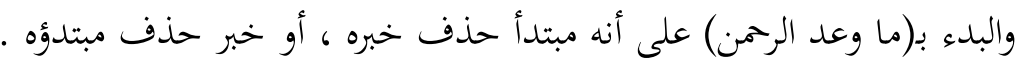

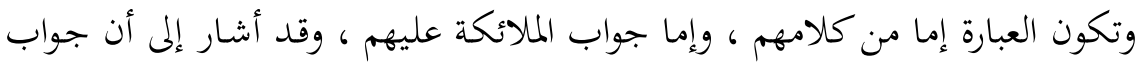

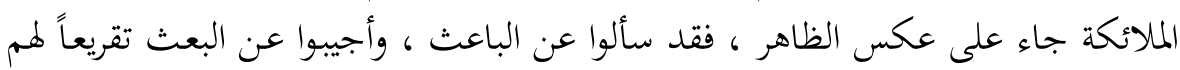

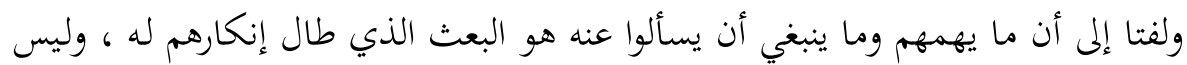


- أما تعليق العلامة الشهاب على هذا الكلام والذي ذكر فيه المصطلح ، فهذا نصه:

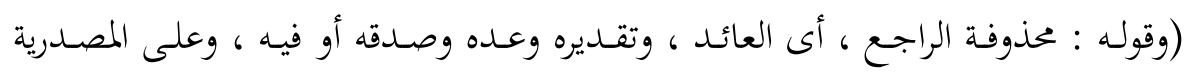

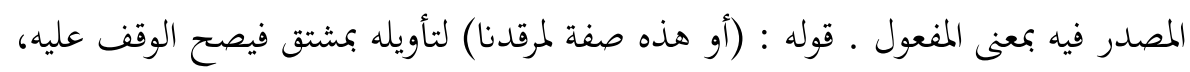

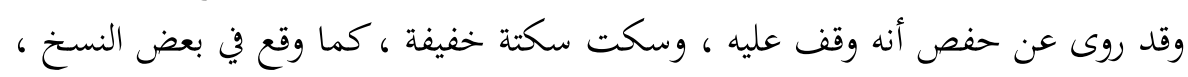

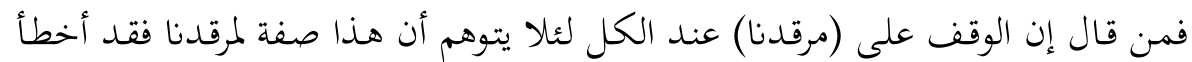

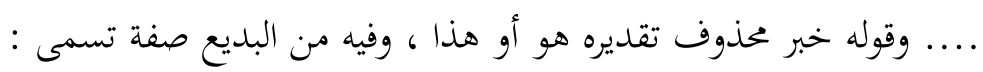

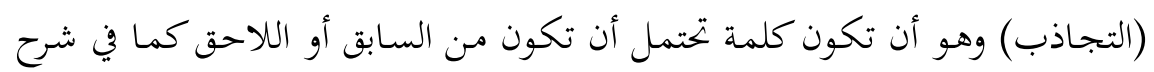

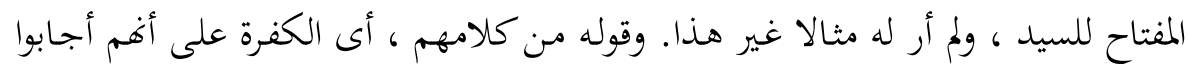

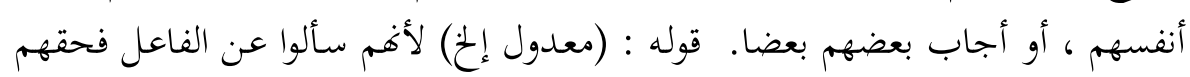

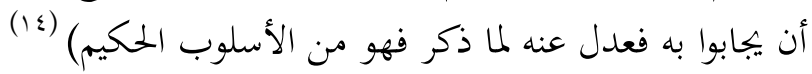

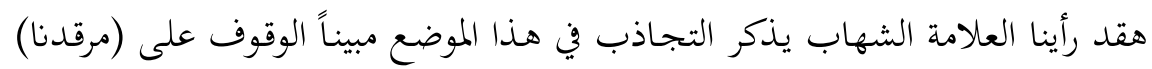

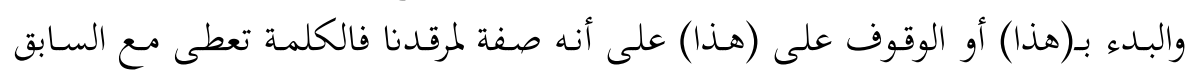

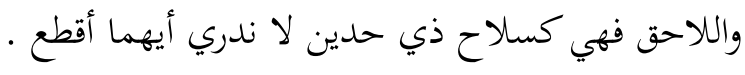

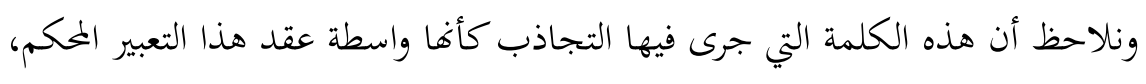

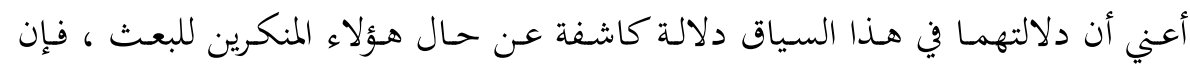

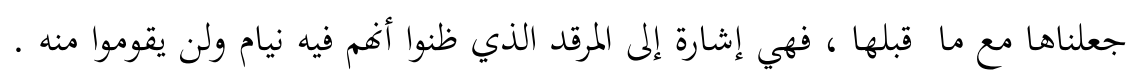

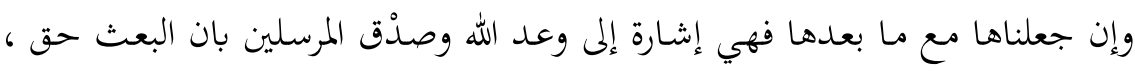

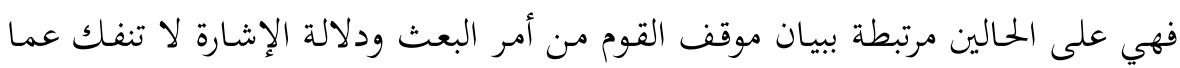

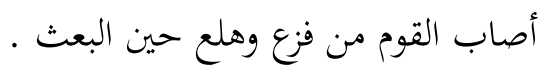

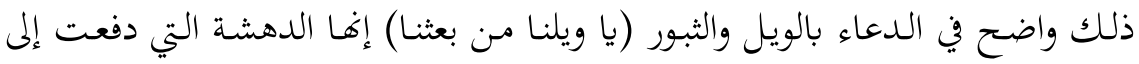

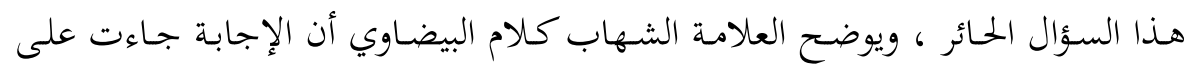

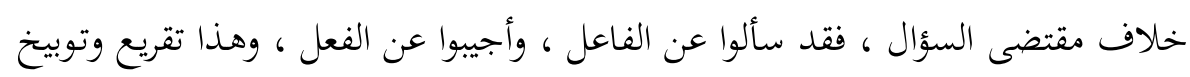

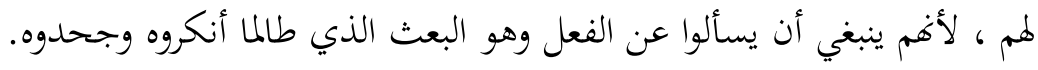

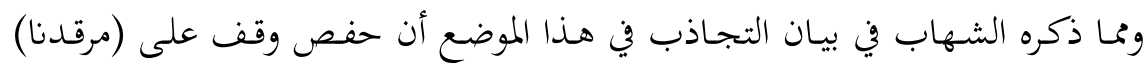

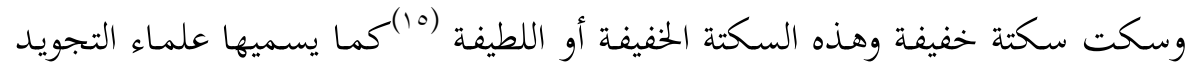
تقدر بمقدار حركتين. وأرى أن هناك علاقة بين دلالمة التجـاذب وهـذه السكتة مـن جهتين : الأولى أن في

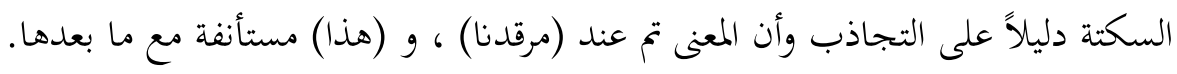


يقول العلامة السمين - رحمه الله - :(وقد تقدم لك أول الكهف أن حفصا يقف على (مرقدنا) وقفة لطيفة دون قطع نفس لئلا يتوهم أن اسم الإشارة تابع لـ(مرقدنا(1) . وسيأتي كلام العلامة السمين كاملا في هذا الموضع.

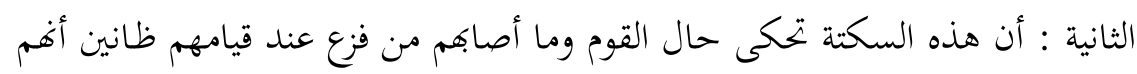

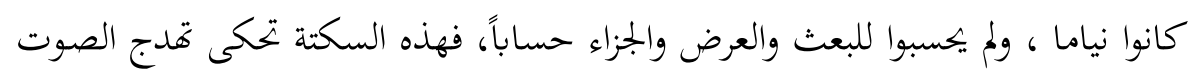

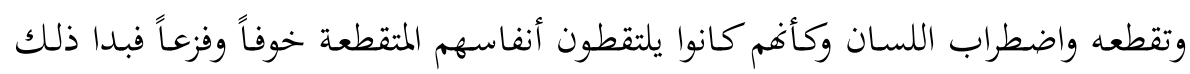
على لساهم ، ولنا أن نتخيل حالة من هب من نومه خائفا مروعاً كيف يتكلم ؟! الأهم

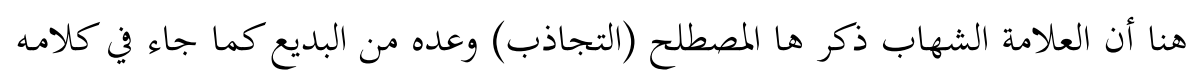
. السابق

ـ وإن كان لنا أن نعلق على كلام الشهاب نقول : إنه قال : (أن تكون كلمة ... فذكر

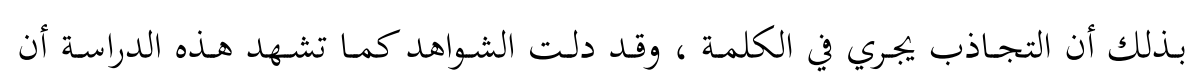

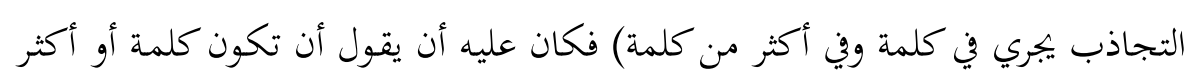

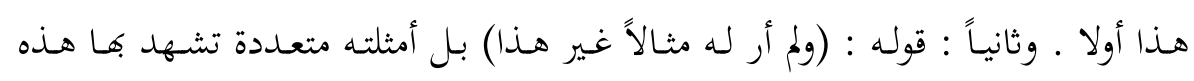

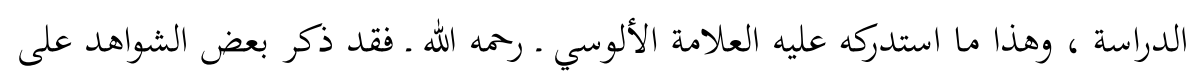

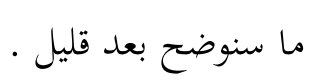
ثالثاً : قوله (تحتمل أن تكون ...) بيان لعطاء التجاذب وفضيلته وازدواجية دلالته ،

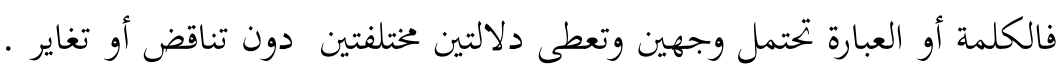

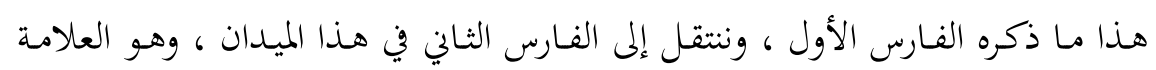

\section{الألوسي. يذكر المصطلح ويستدرك على الشهاب}

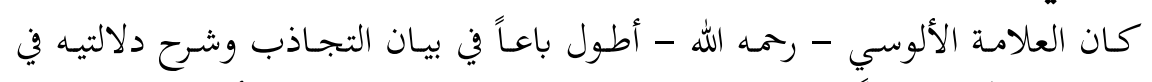

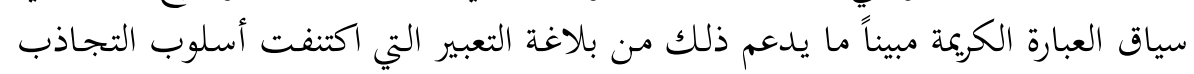

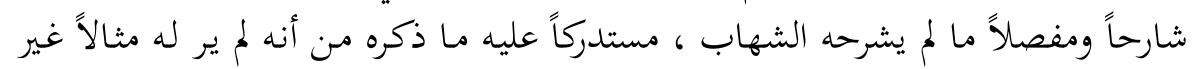

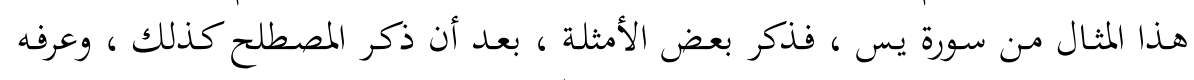

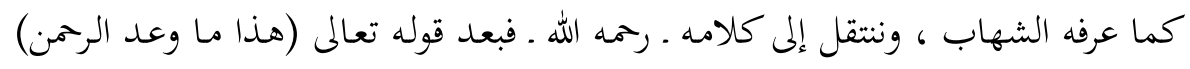

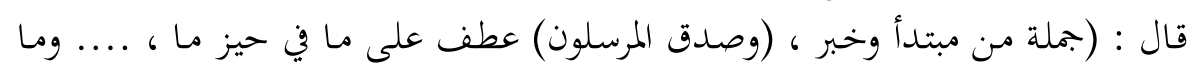

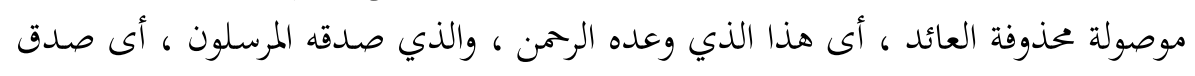


فيه ، مـن قولم : صدقت زيدا الحمديث أى صدقته فيه .... أو مصدرية أى هـا وعدـ

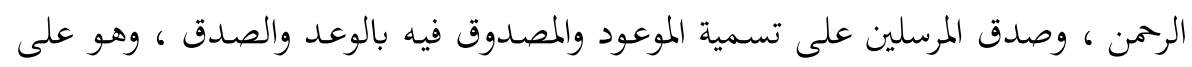

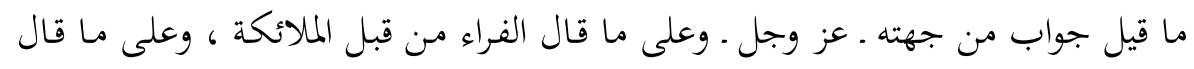

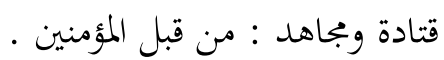

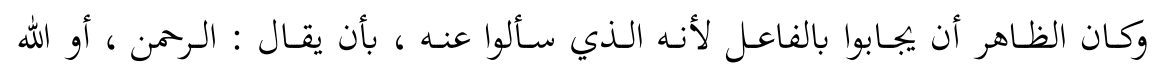

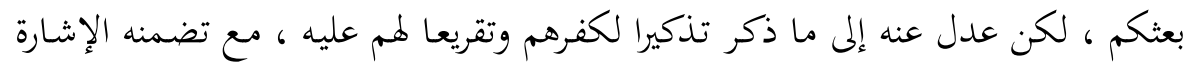

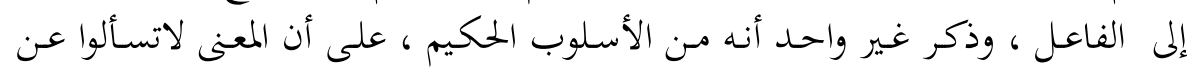

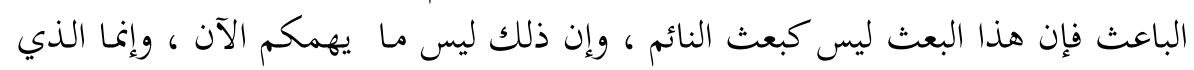

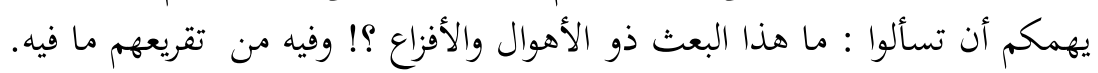

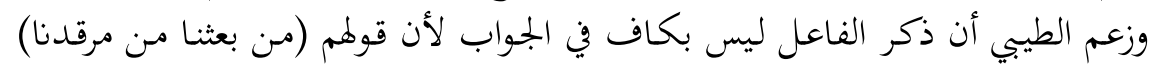

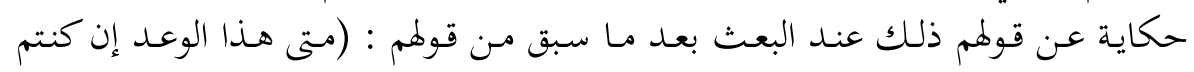

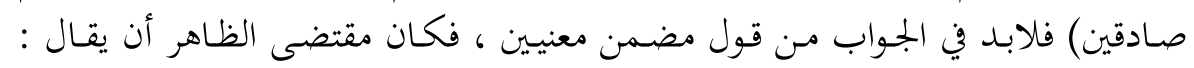

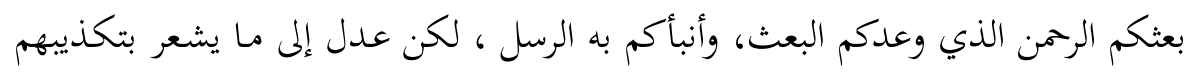

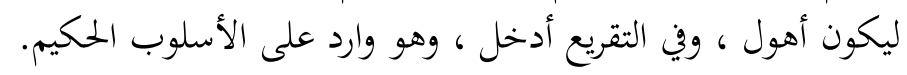

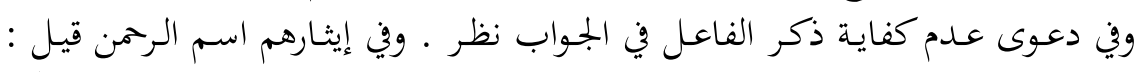

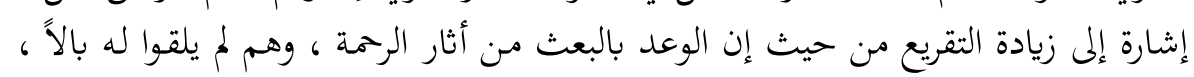

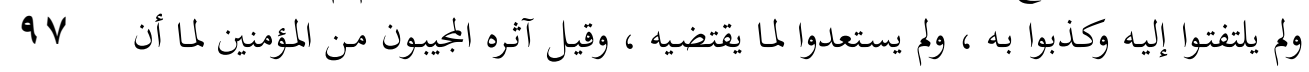

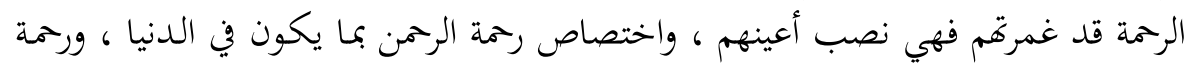

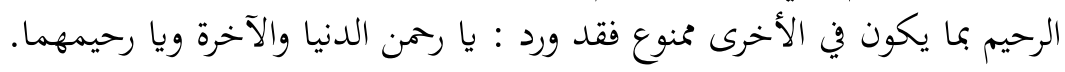

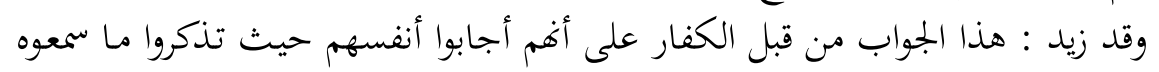

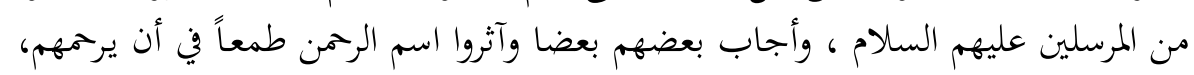

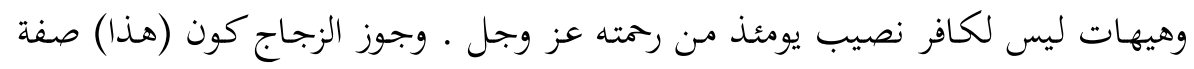

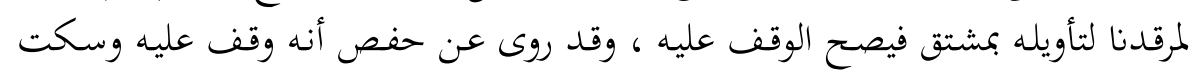

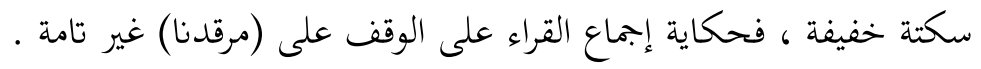

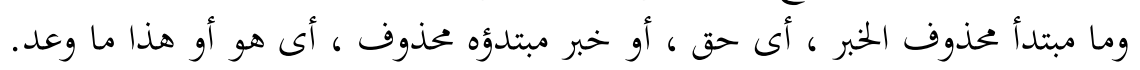

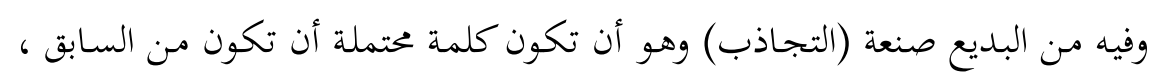

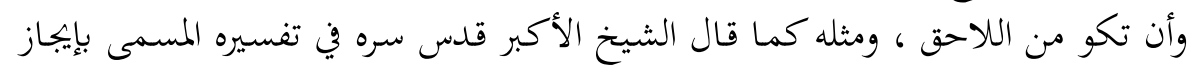

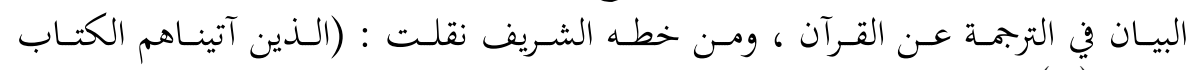

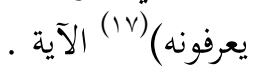

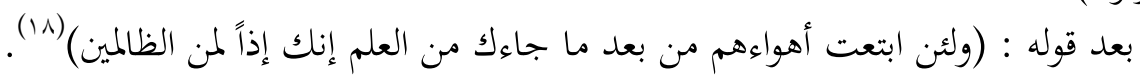




$$
\text { وقوله تعالى : (فيه هدى) بعد (لا ريب) (19) فليحفظ)(.r). }
$$

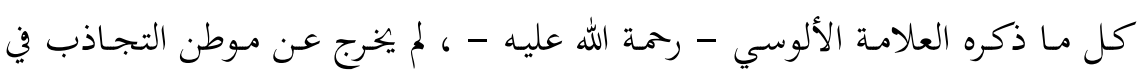

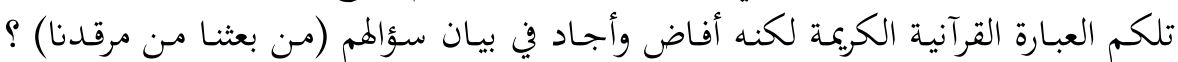

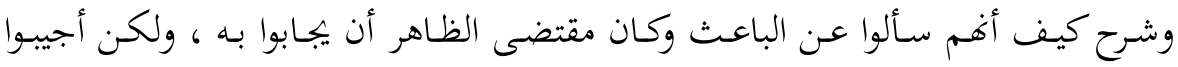

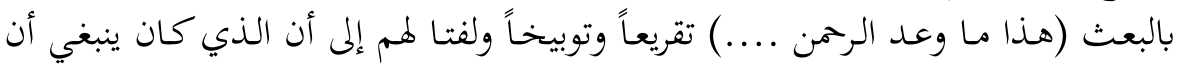

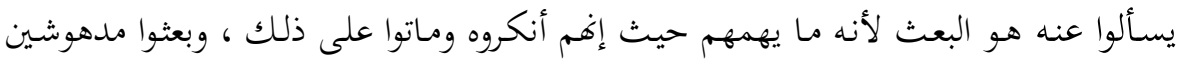
متعجبين منه . ئساعل

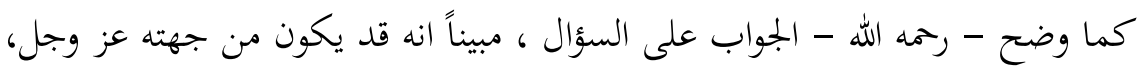

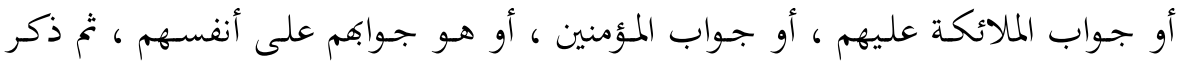

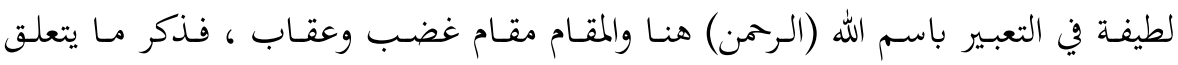

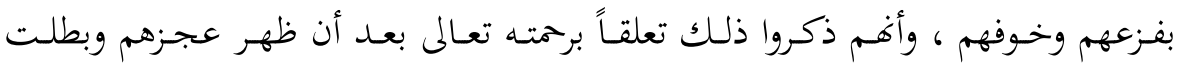

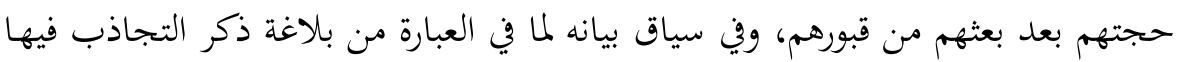

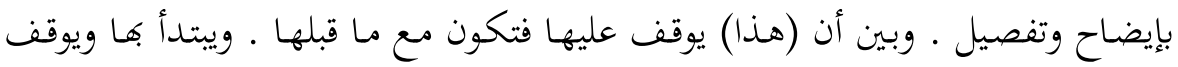

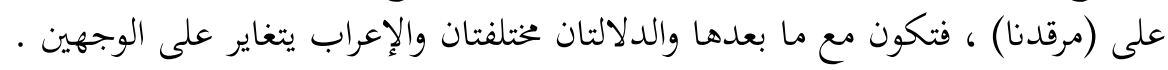

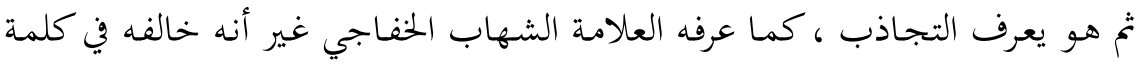

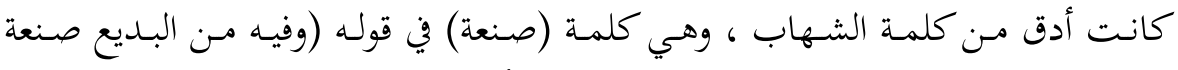

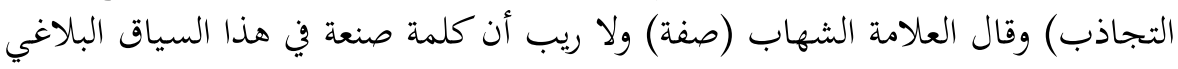

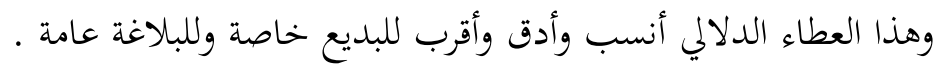

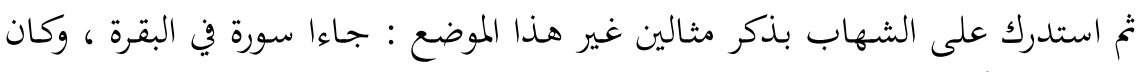

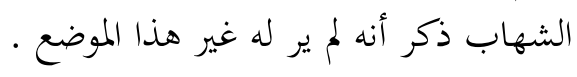
العلامة الزمخشري.

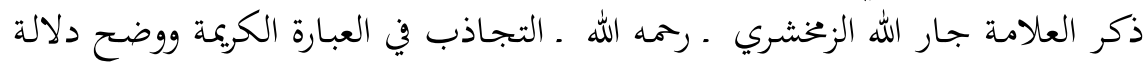

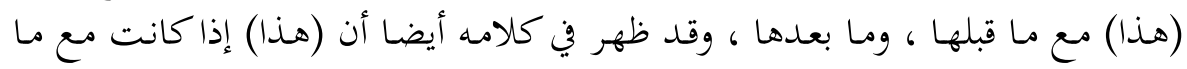

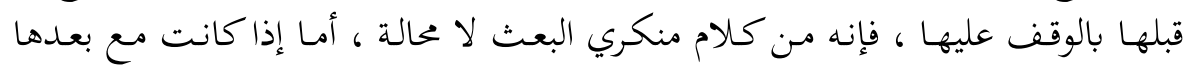

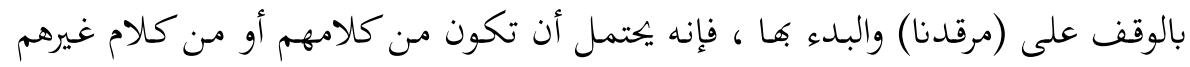

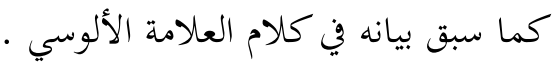

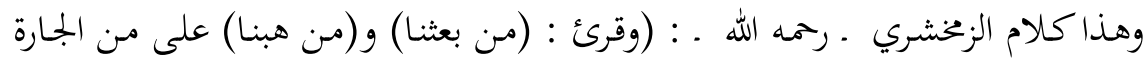

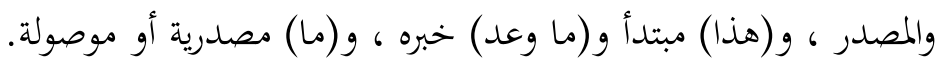

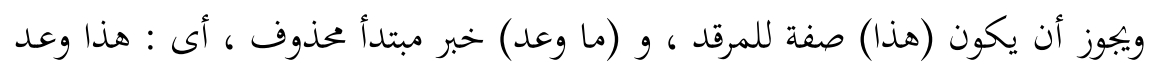

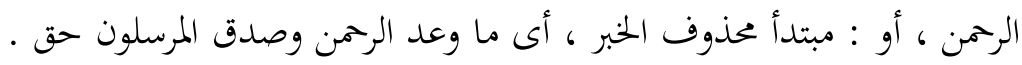




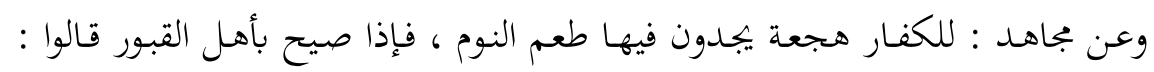

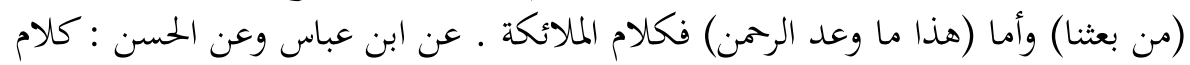

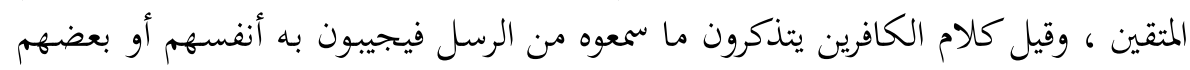
بعضا .

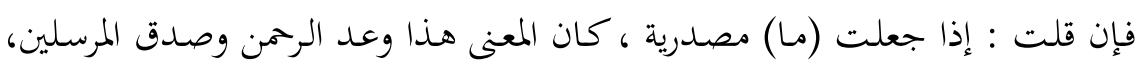

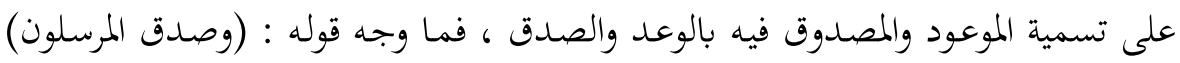

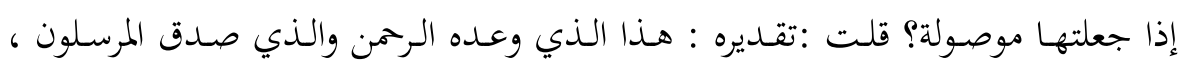

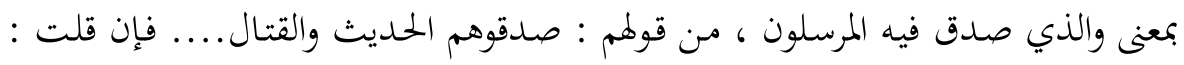

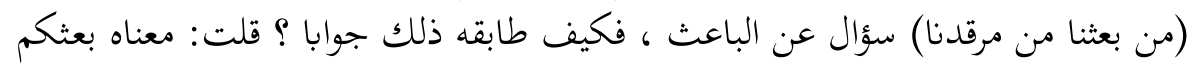

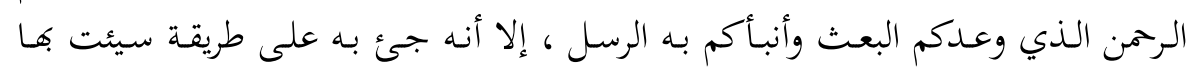

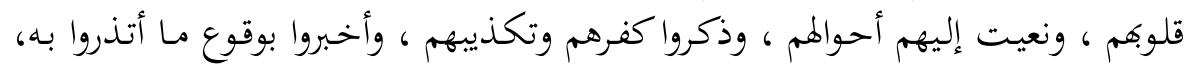

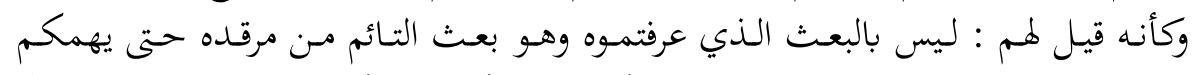

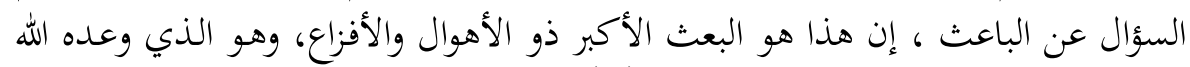

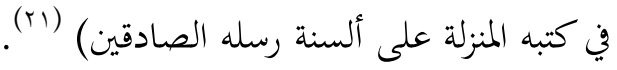

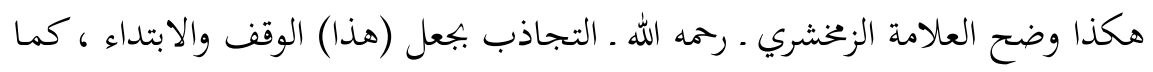

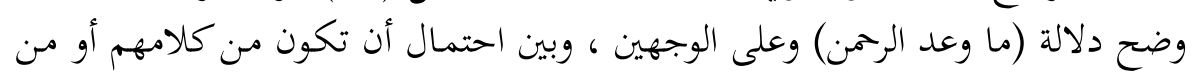

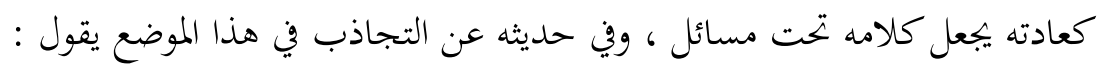

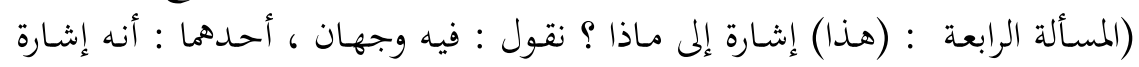

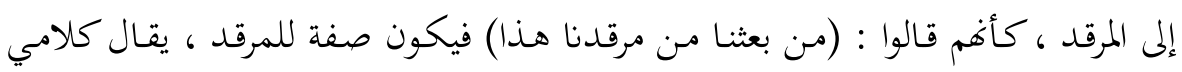
هذا صدق. وثانيهما : (هذا) إشـارة إلى البعث ، أى هذا البعث مـا وعـد بـه الرحمن وصدق فيه المرسلون.

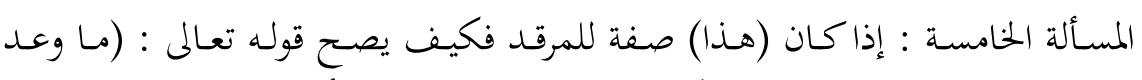

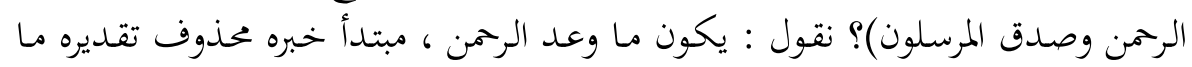

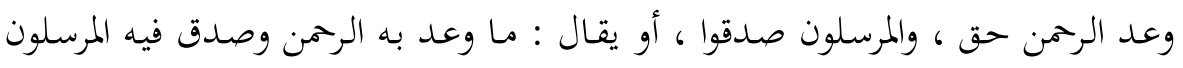

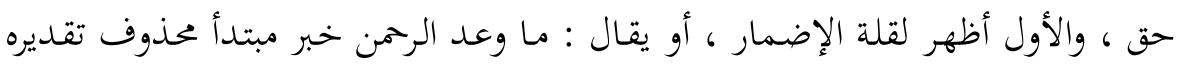

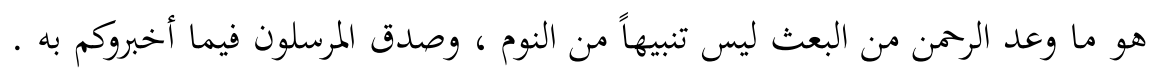

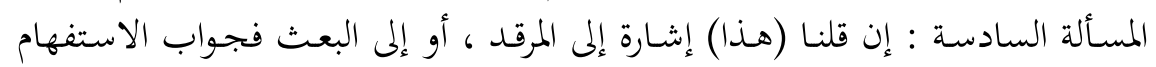

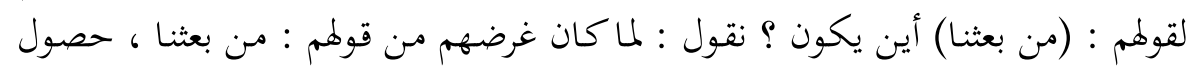




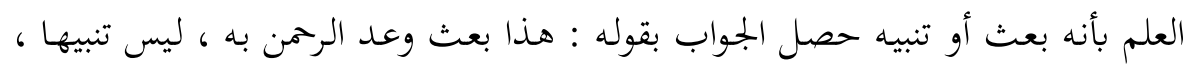

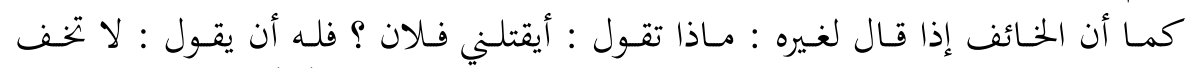

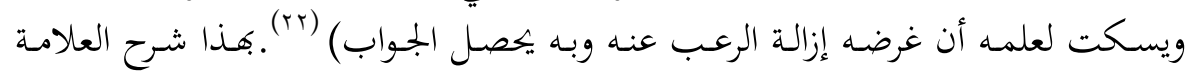

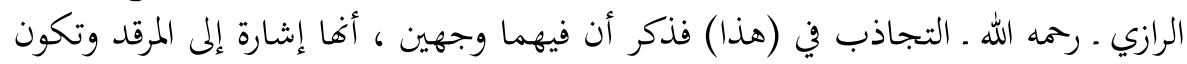

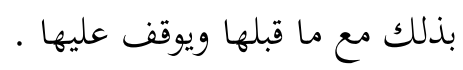

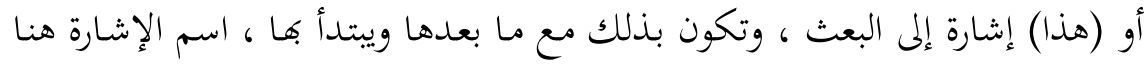

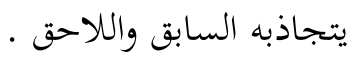

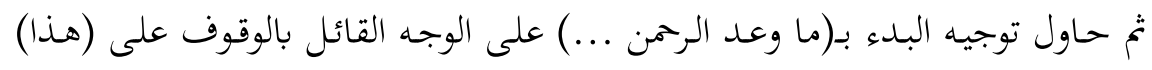

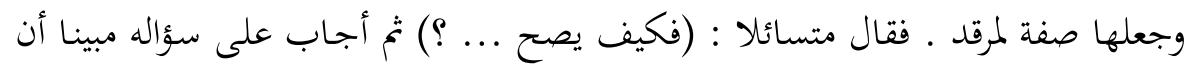

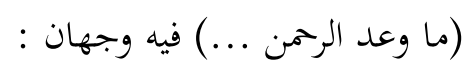

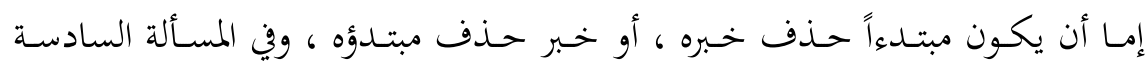

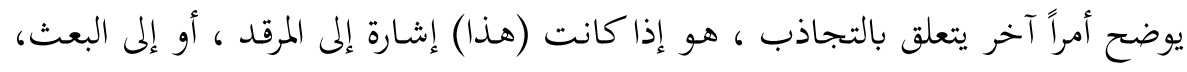

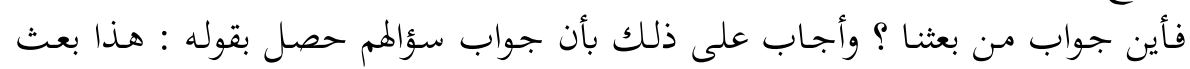

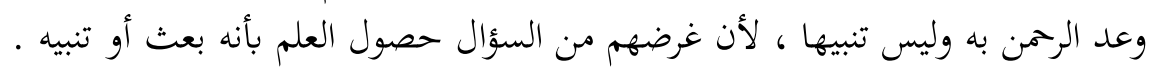

يوضح العلامة السمين وجهي التجاذب في (هذا) رابطاً ذلك بالوقف والابتداء موجها

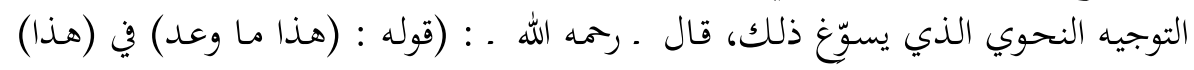

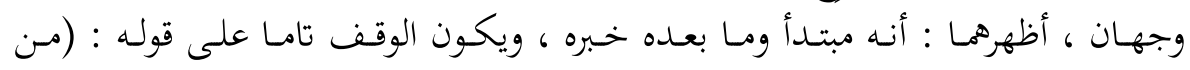

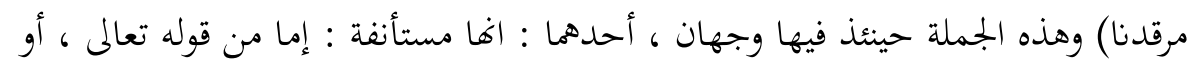

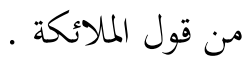

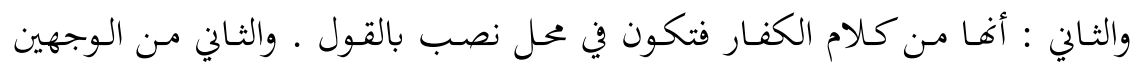

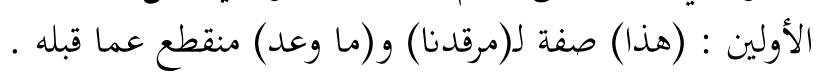

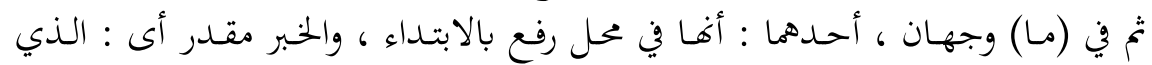

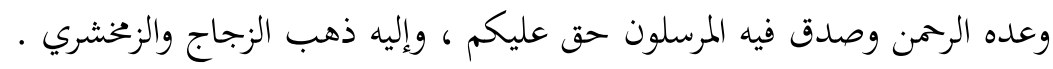

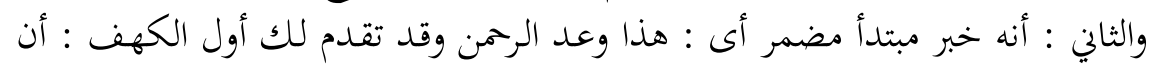

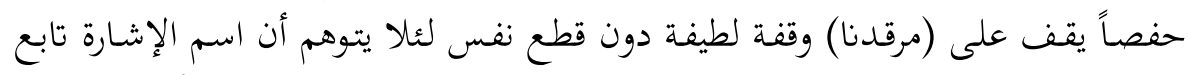

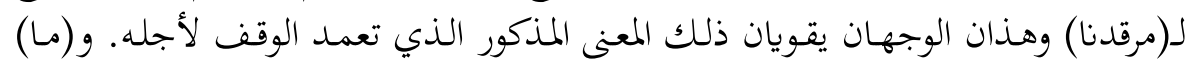

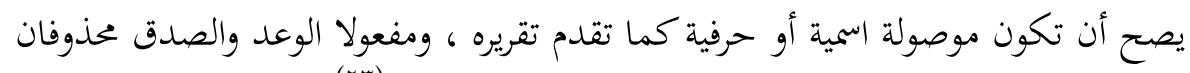

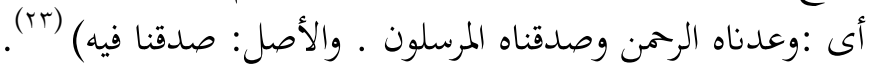


ما أجمل ما ذكره العلامة السمين هنا رابطاً سر الوقفة اللطيفة على (مرقدنا) بالتجاذب،

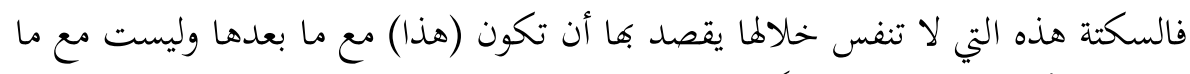

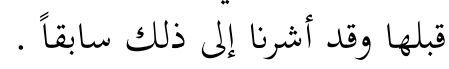
العلامة القرطبي

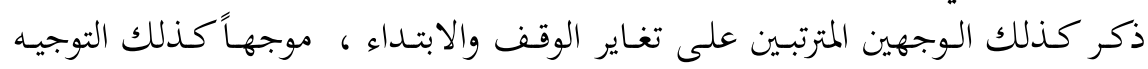

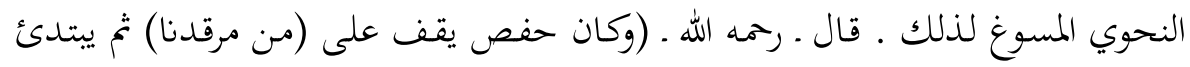

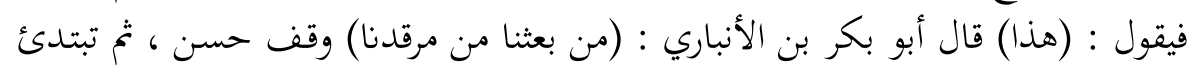

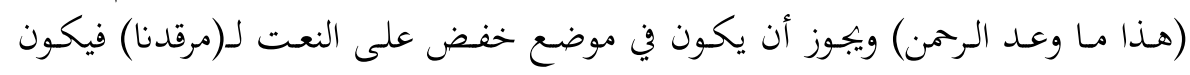

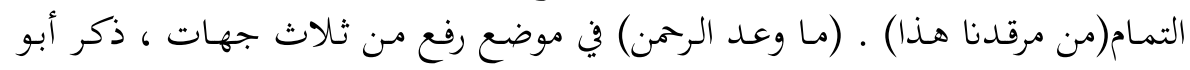

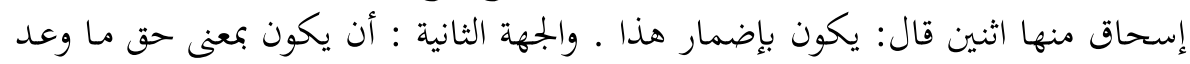

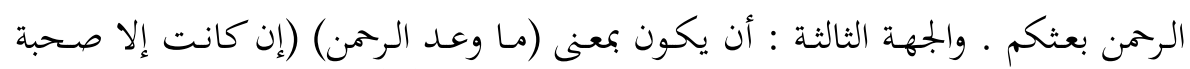

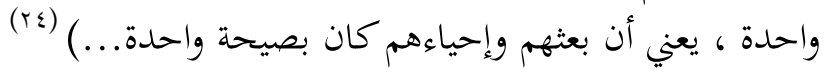

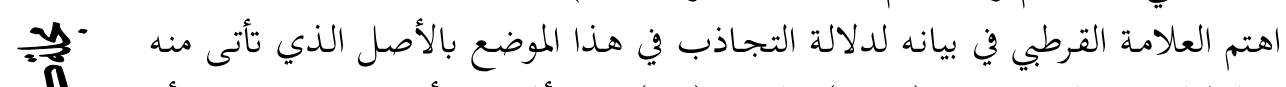

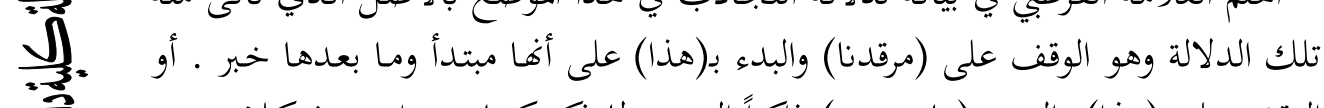

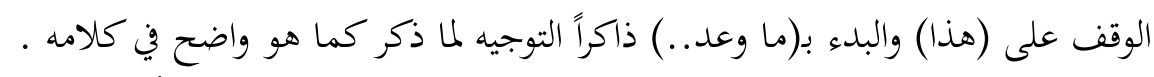

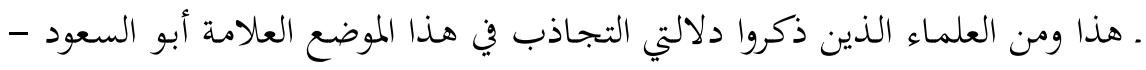

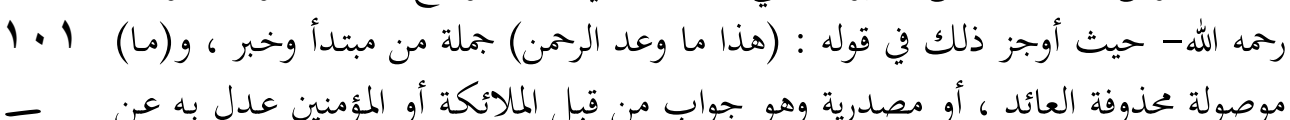

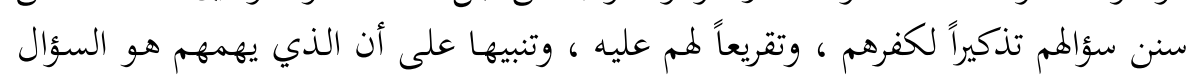

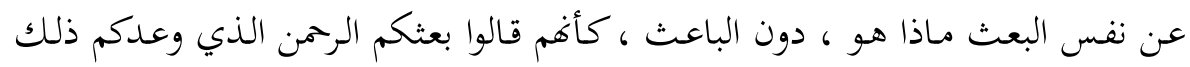

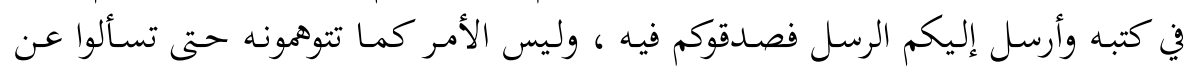

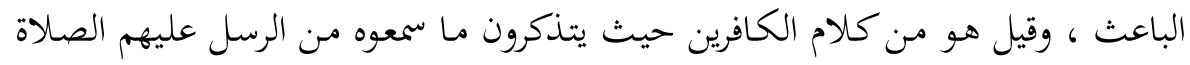

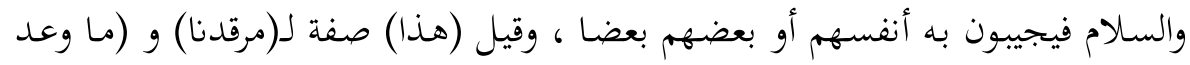

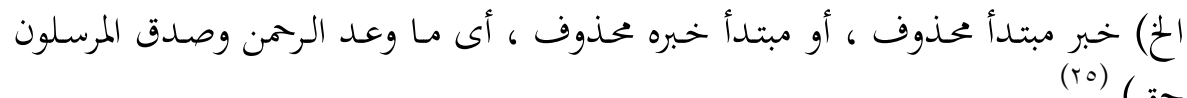

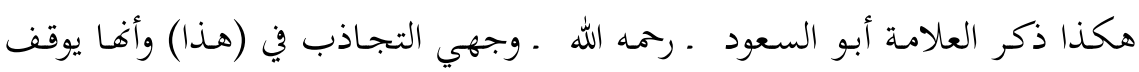

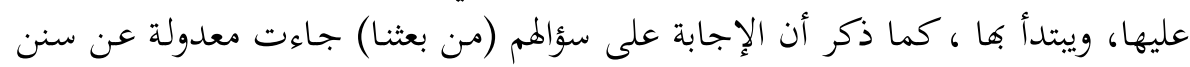

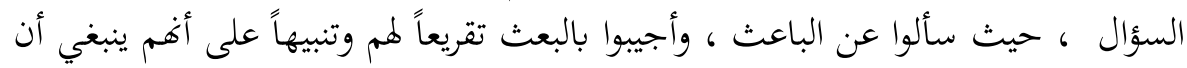

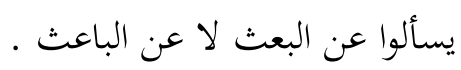

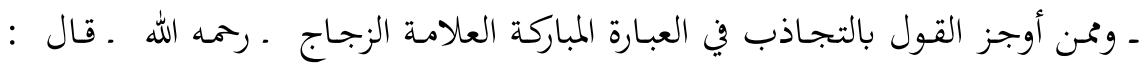

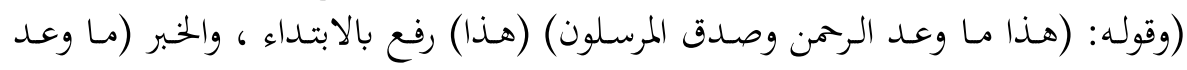




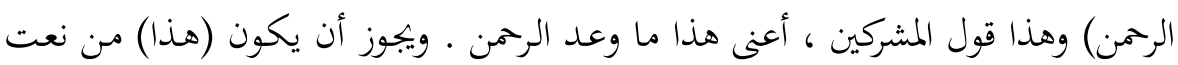

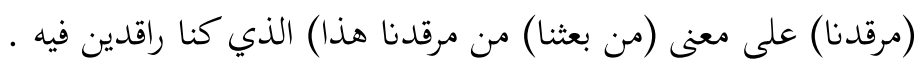

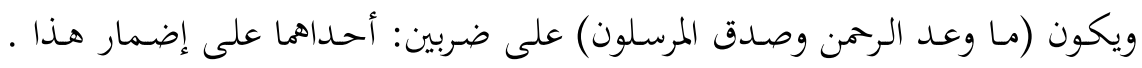

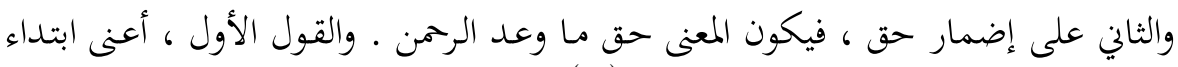

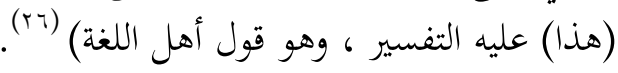

هكذا ذكر العلامة الزجاج التجاذب في (هذا) ورجح القول التعة) الأول وهو الابتداء بـ(هذا) والوقف على (مرقدنا) .

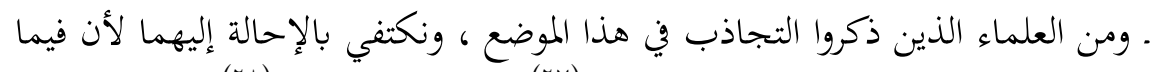

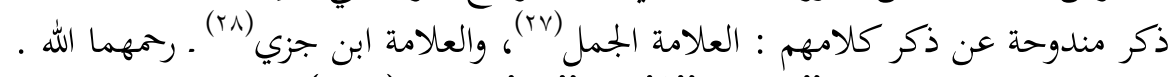

\section{المبحث الثاني: التجاذب في ( فيه الجيه}

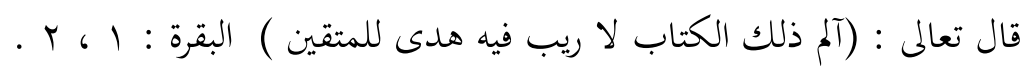

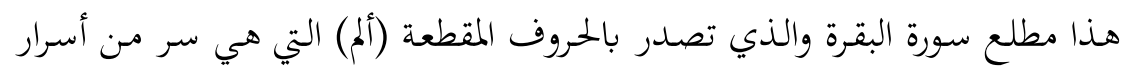

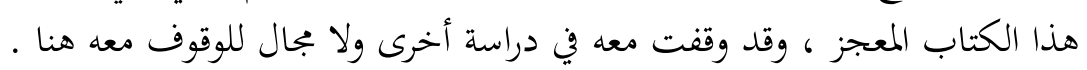

\section{دلالة اسم الإشارة}

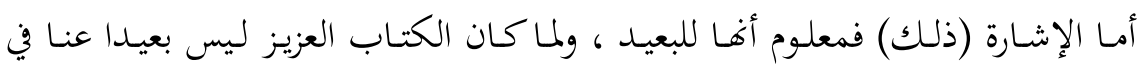

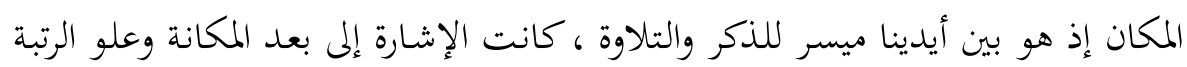
ورفعة المنزلة .

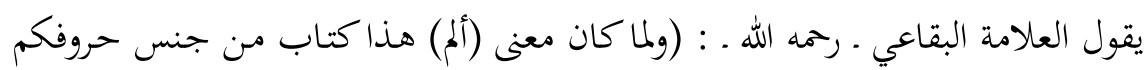

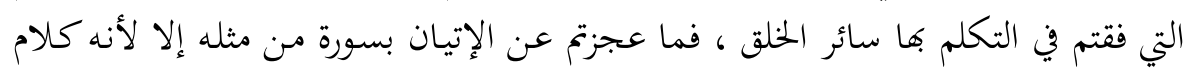

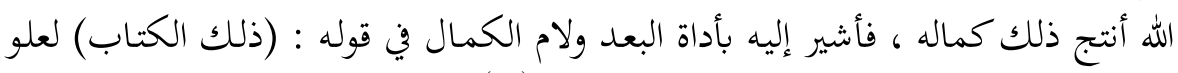

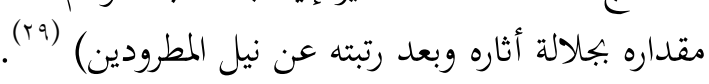

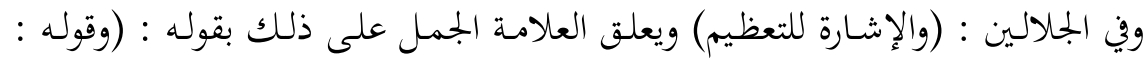

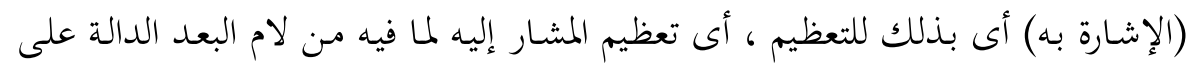

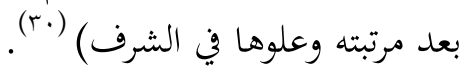

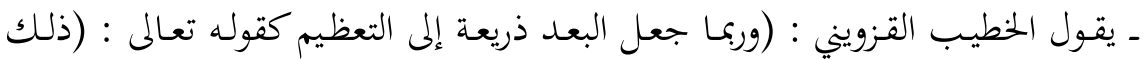

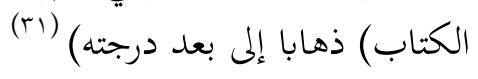

وعليه يعلق أبو يعقوب المغربى بقوله : ( أى ذلك الرفيع المنزلة في البلاغة ، العزيز المرتبة

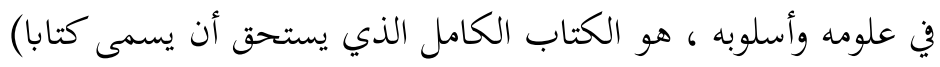

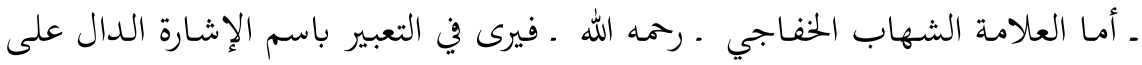

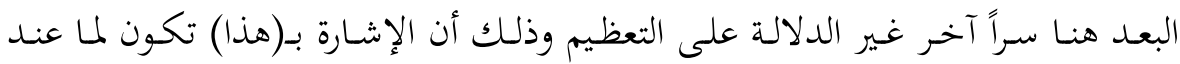


المتكلم ، والإشارة بـ(ذلك) تكون لما انفصل عن المتكلم أى عند المخاطب وغيره، فيقول

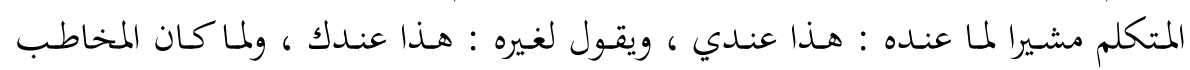

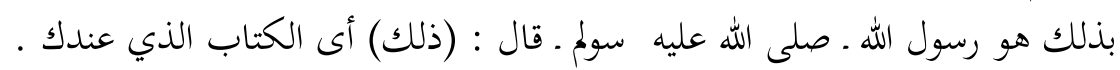

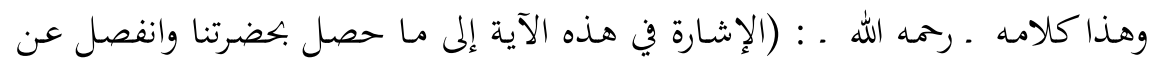

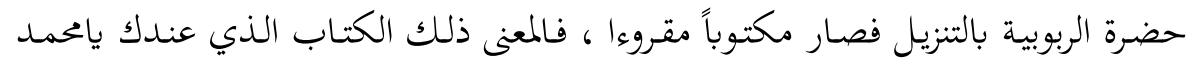

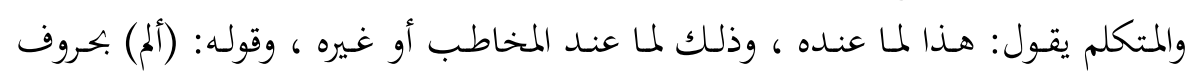

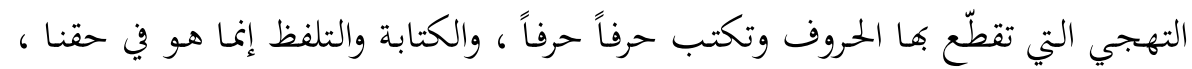

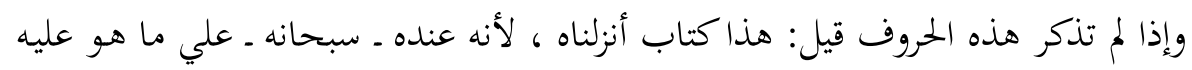

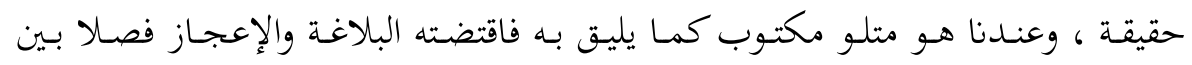

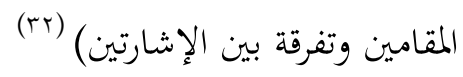

\section{موضع التجاذب}

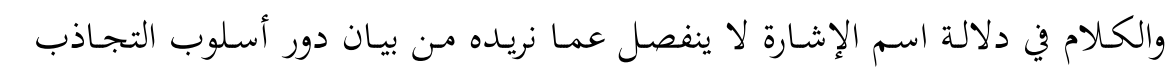

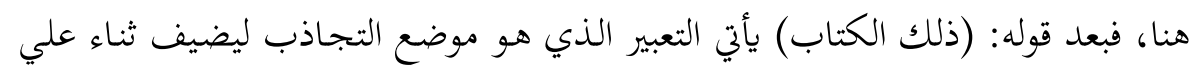

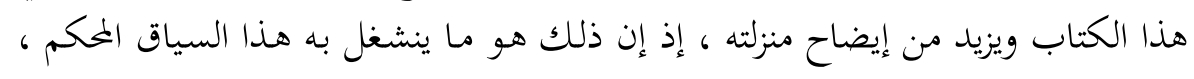
(لاريب فيه) ذلك قوله: - 20 - ملكاب

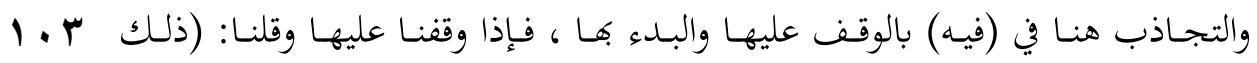

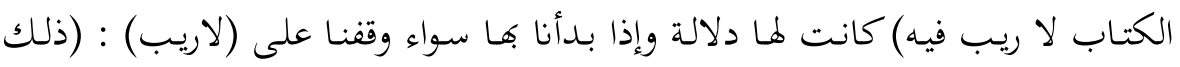

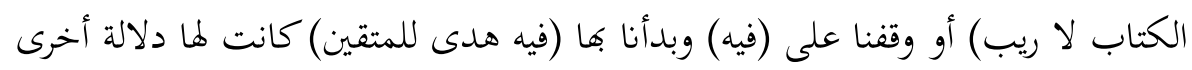

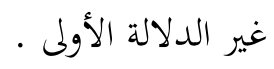
نعم الكلمـة هي الكلمة لكنها ذات وجهـين مختلفين وتعطي دلالتين متغايرتين دونما

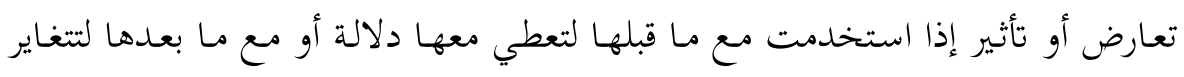
دلالتها .

والذى أريد إيضاحه هنا هو ان الذي جرى عليه كلام جل علماء التفسير الوقف عليها

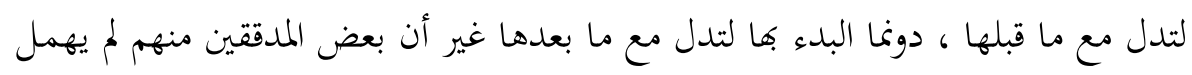

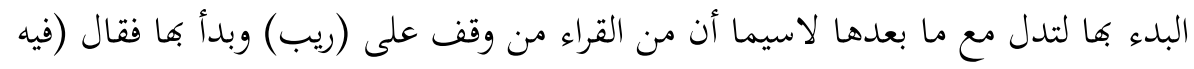
هدى للمتقين) 


\section{العلامة الشهاب والبيضاوي}

ممن شرح المعنى بالوقوف على(فيه) هكذا (ذلك الكتاب لا ريب فيه) العلامة الشهاب الخفاجي والعلامة البيضاوي ـ رحمة الله عليهما ـ فالشهاب يوضحً أن (لا ريب فيه) للعاقل

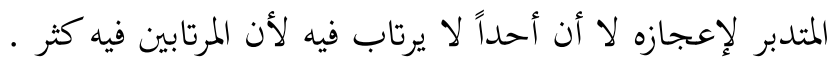
قال : (معناه أنه لوضوحه وسطوع برهانه بحيث لا يرتاب العاقل بعد النظر الصحيح في

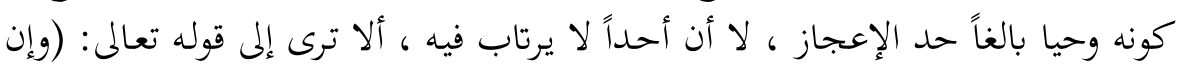

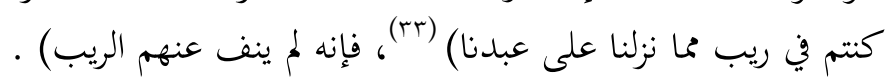
ويقول العلامة الشهاب أيضا بعد كلام مفصل في تعليقه على كلام البيضاوي : (إشارة إلى أنه ليس المنفي ههنا إلا كون القرآن محلا صالحا في نفسه لتعلق الريب به ، و ومظنة له له بل هو لوضوح الدلالة وسطوع البرهان على كونه حقا منزلا من عند الله بحيث لا ينبغي

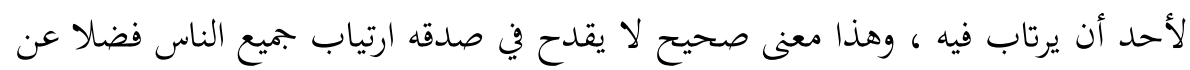

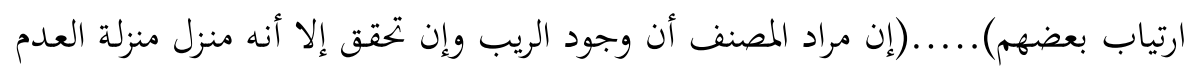
لأنه لايصدر عن عاقل تدبره ، ومايصدر عن غيره لاعبرة به فكأنه غير موجود رأسا فنفيه

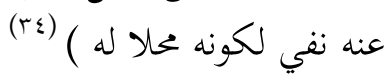
هكذا بين العلامـة البيضاوي والعلامة الشهاب أن المعنى بالوقوف على (فيه) نفى أن أن إنهابه

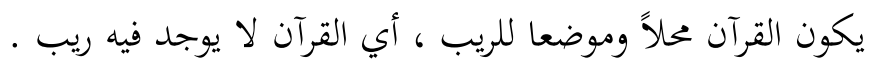
ثم يكـون البـدء بـ(هدى للمتقـين) ويبعـل البيضـاوي (هـدى) حهالاً مـن الضـمير المجرور (فيه) يقول: (وهدى حال من الضمير المجرور ، والعامل فيه الظرف الواقع صفة للمتقين) ويعلق الشهاب بقوله : (والمصدر وقع حالا مبالغة بجعله عين الهدف ..... والمراد بالظرف وفرون لفظ (فيه) لأن الظرف يطلق على أسماء الظروف نحو عند وحيثث وعلى الجـار والمجرور

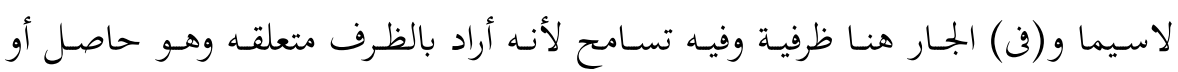

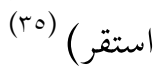

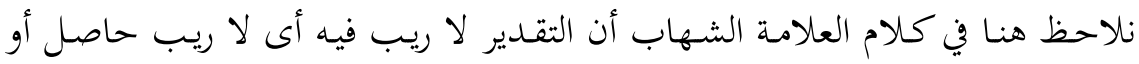

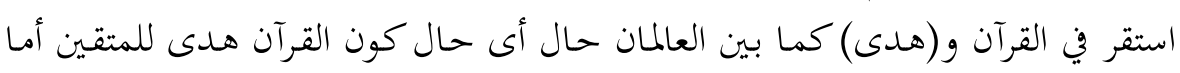
الوقف على (لا ريب) وبيان التوجيه الدلالي له عند هذين العالمين فسنوضحه بعد بيان المعنى بالوقوف على(فيه).

- وفي الجلالين أن (هدى) خبر ثان والخبر الأول (لا ريب فيه) والمبتدأ (ذلك) قـال : (وجملـة النفـي خـبر مبتـدؤه (ذلك) والإشـارة بـه للتعظيم (هـدى) خهبر ثان 
- كما يفسر العلامة الجمل المعنى على الوقوف على (فيه) لتعطى المعنى مع ما قبلها

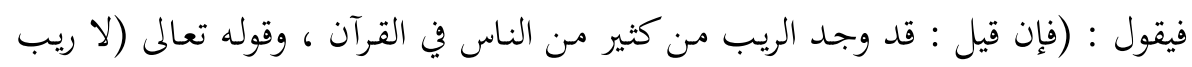

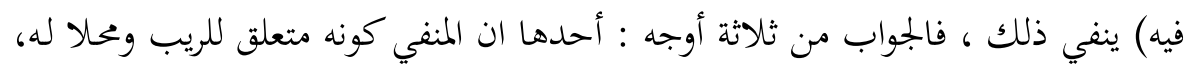

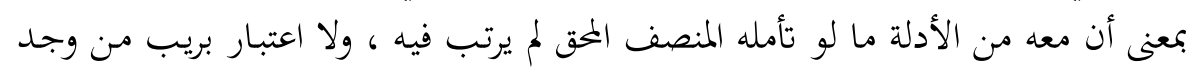

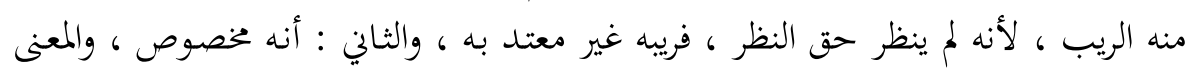

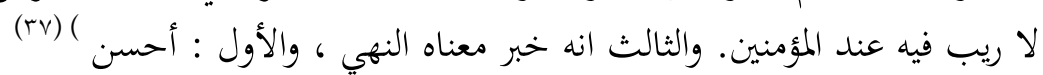

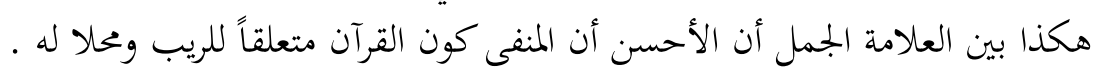

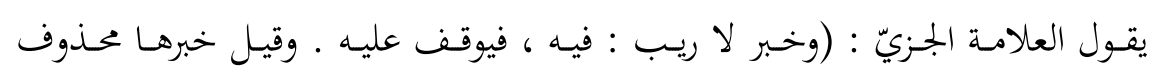

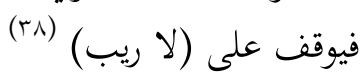
واضح أن كلمة (فيه) هنا يأتي معناهـا مع مـا قبلها بمعنى أن القرآن ليس موضعاً طولا

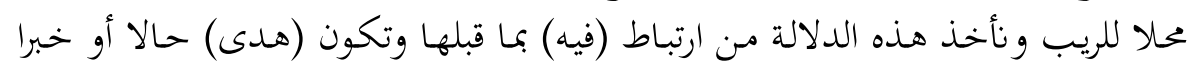

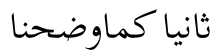
- أمـا البدء بـ(فيه) (فيه هـدى للمتقـين) فيغير المعنى ويعطينـا وجهاً أخر غير الأول

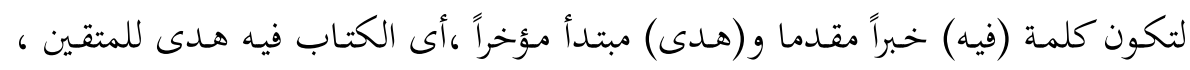

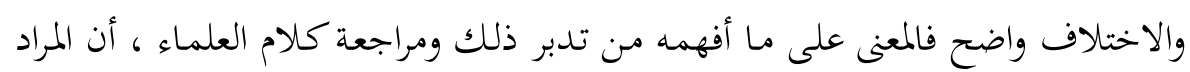

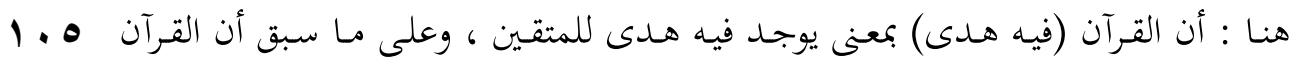

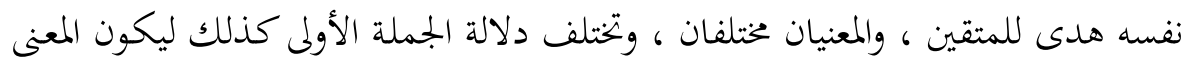

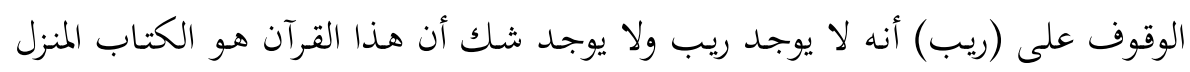

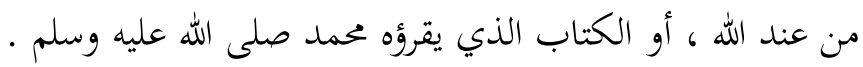
الزخشري وابن المنير

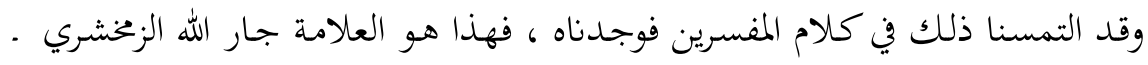

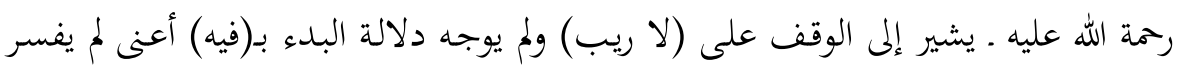

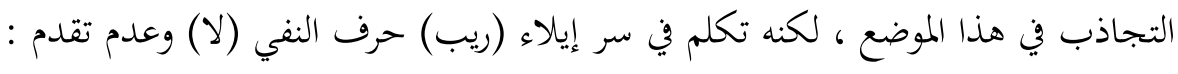

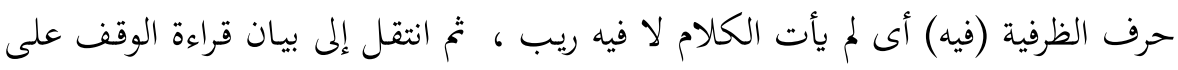

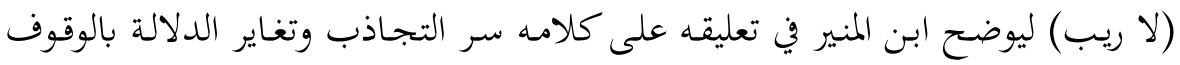

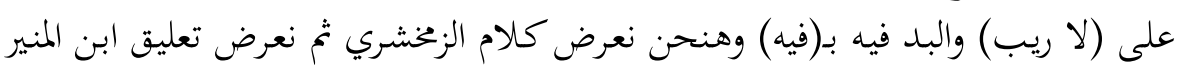

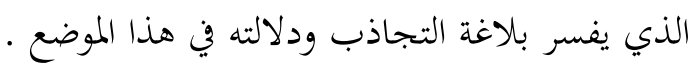

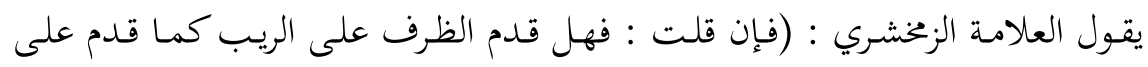

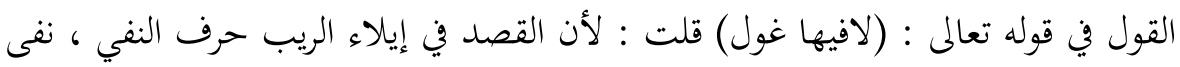


الريب عنه وإثبات أنه حق وصدق ، لا باطل وكذب كما كان المشركون يدعونه. ولو أولى آلى

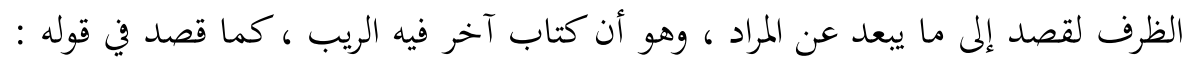
(لا فيها غِول)

تفضيل خمر الجنة على خمور الدنيا بأها لا تغتال العقول ، كما تغتالها هي ، كأنه قيل:

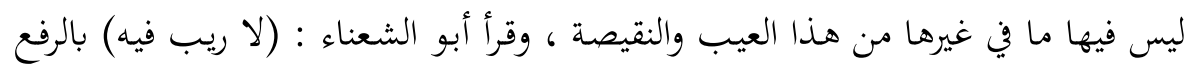

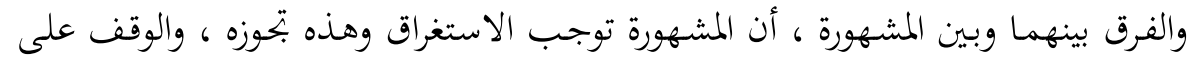

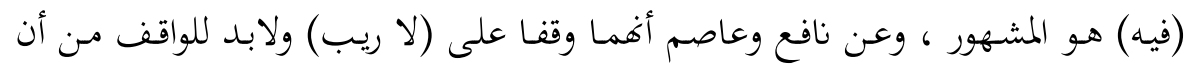

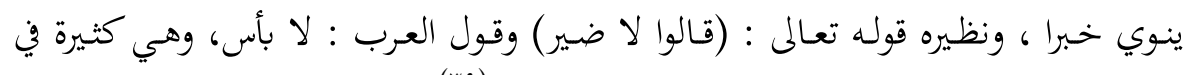

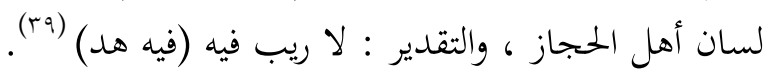

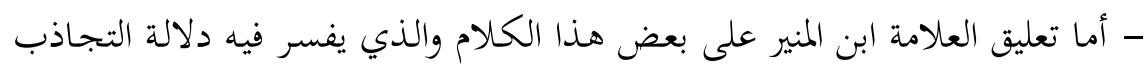

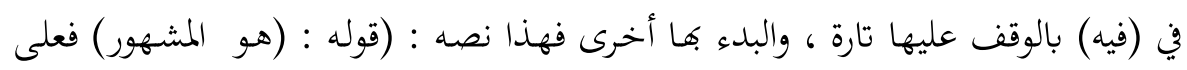

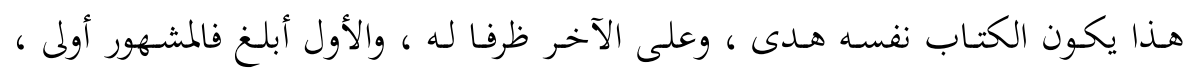

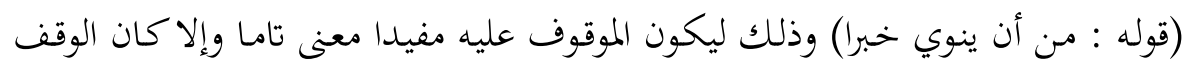

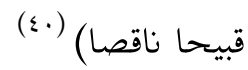
ونلاحظ أن ابن المنير فضل الوقف على (فيه) وجعله أبلغ ولم يعلل لوجه البلاغة سوى

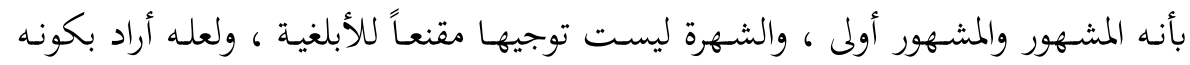

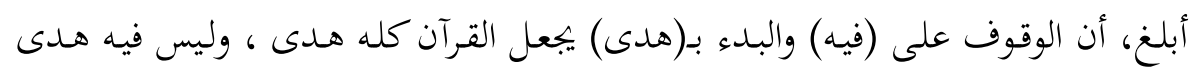

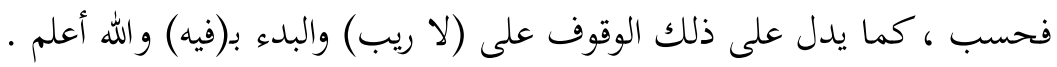

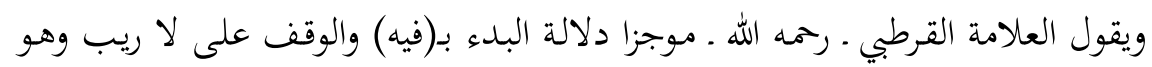

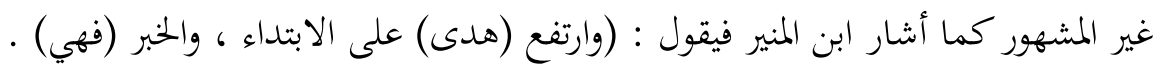

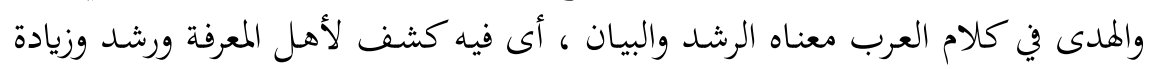

$$
\text { بيان وهدى ) (1) }
$$

\section{عود إلى رأي البيضاوي والشهاب}

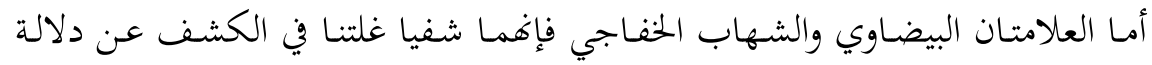

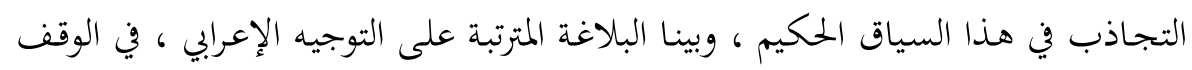

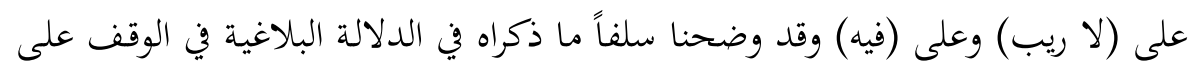

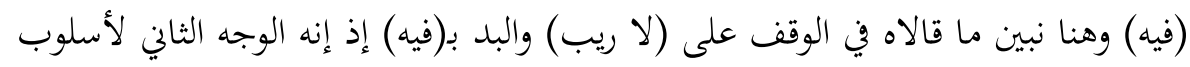
التجاذب. 
يقول البيضاوي : (وهدى ، نصب على الحال ، أو الخبر محذوف كما في (لا ضير)

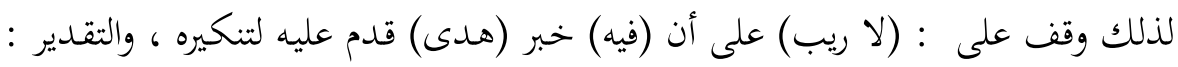

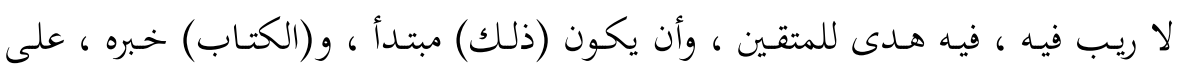

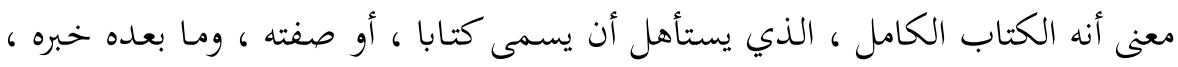

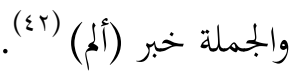

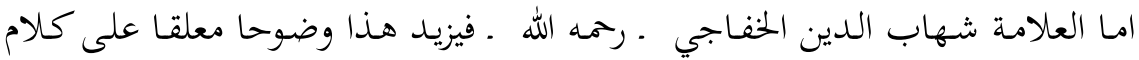

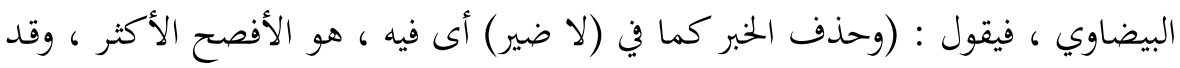

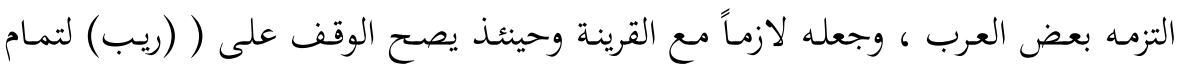

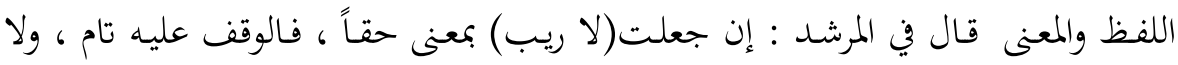

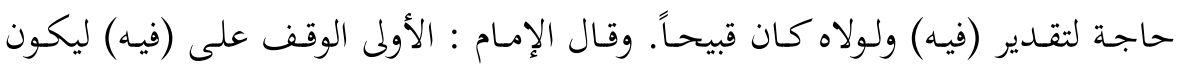

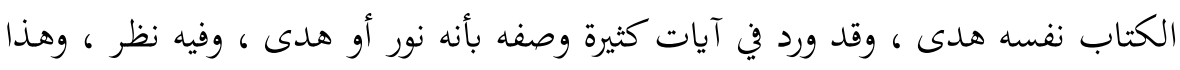

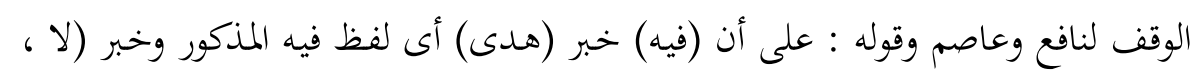

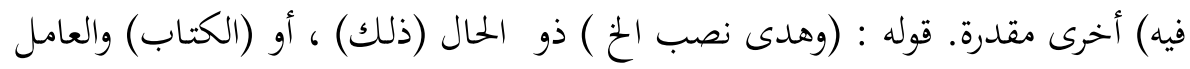

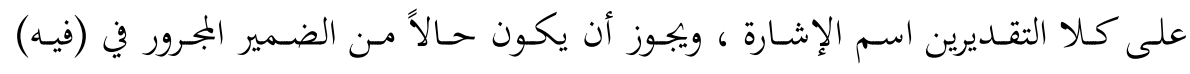

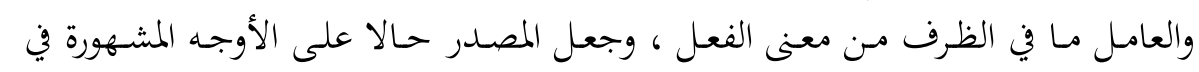
I. V (أمثاله) (والمالم)

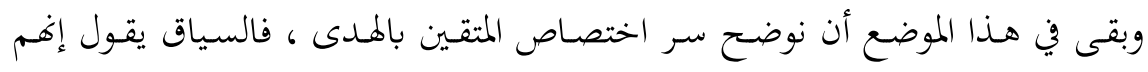

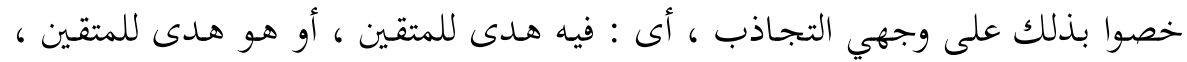

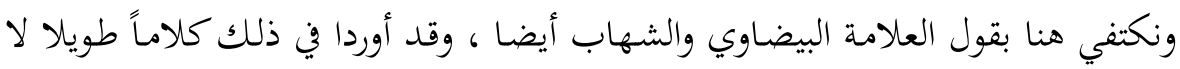

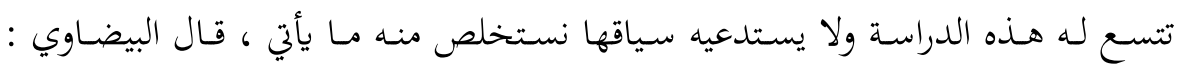

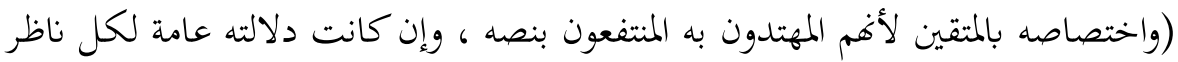

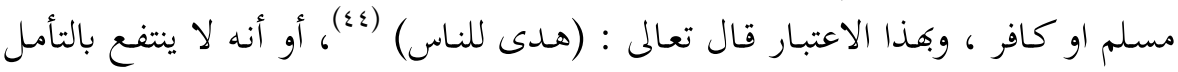

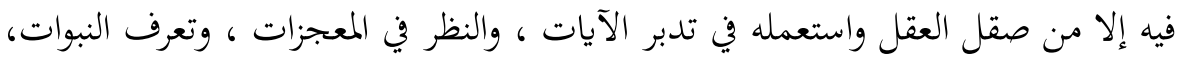

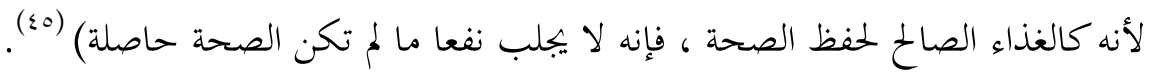

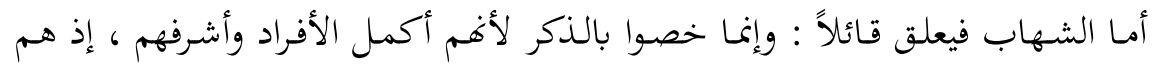

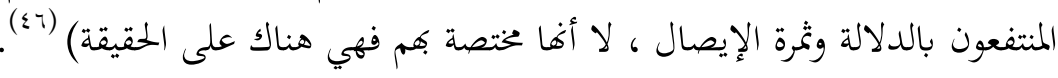




\section{المبحث الثالث: التجاذب في ( لـكــم )}

قال تعالى : (والأنعام خلقها لكم فيها دفء ومنافع ومنها تأكلون) سورة النحل: 0.

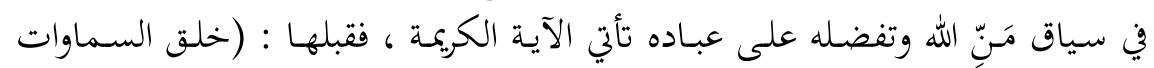

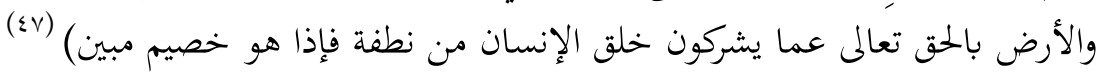

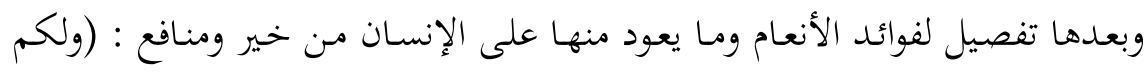

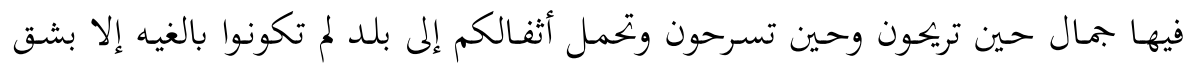

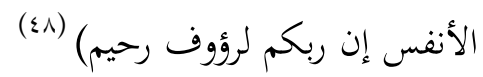

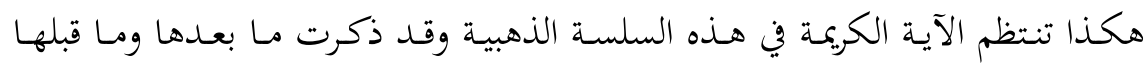

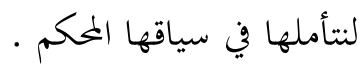

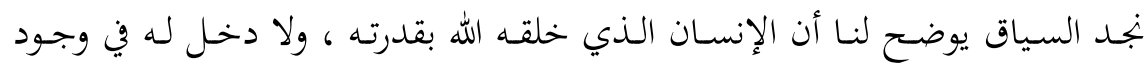

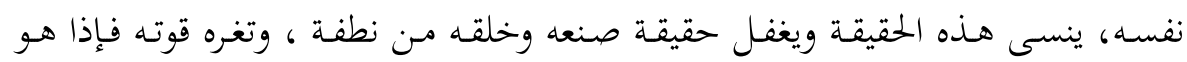

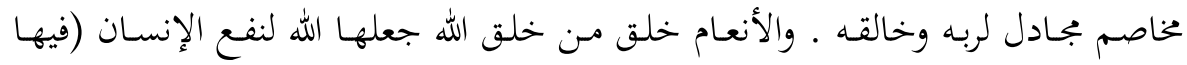

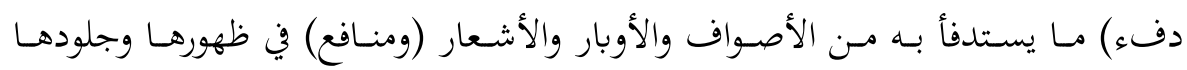

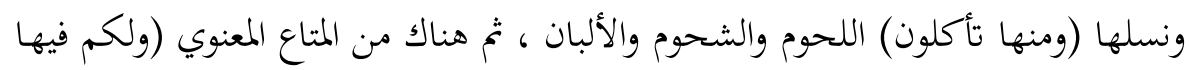

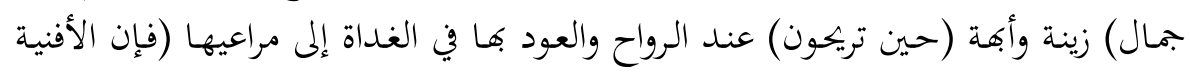

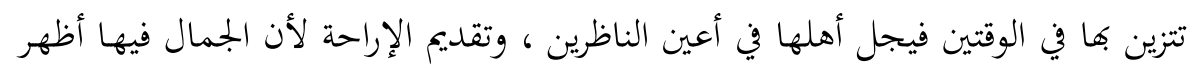

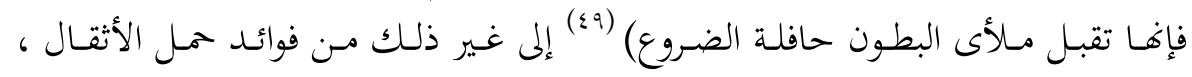
والاعتماد عليها في الأسفار.

\section{موضع التجاذب}

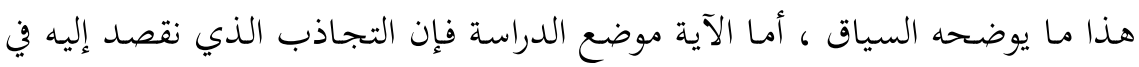

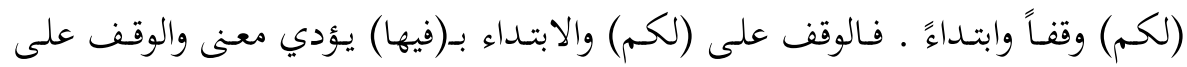

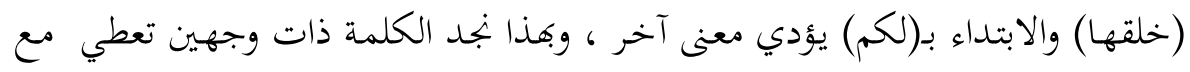

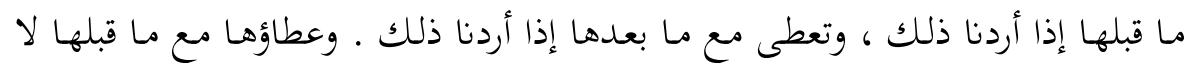

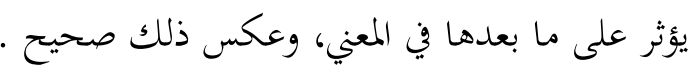

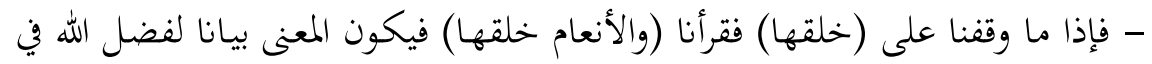

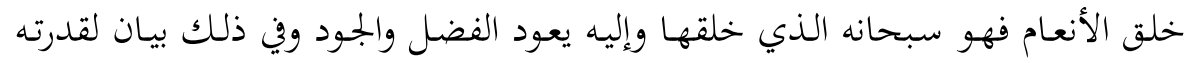

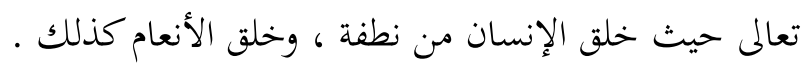

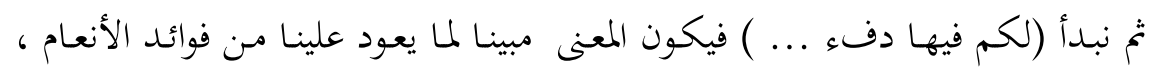

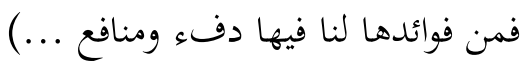


- وإذا ما وقفنا على (لكم) فقرأنا : ( والأنعام خلقها لكمم) فيكون المعنى بيانا لعلة

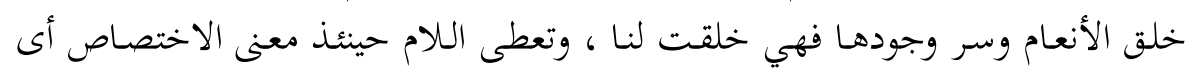

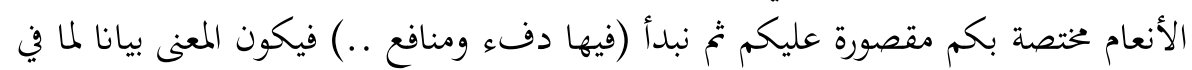

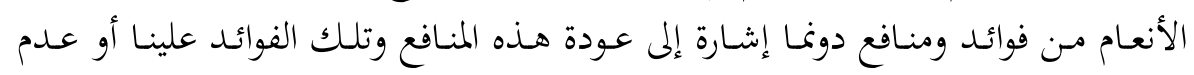

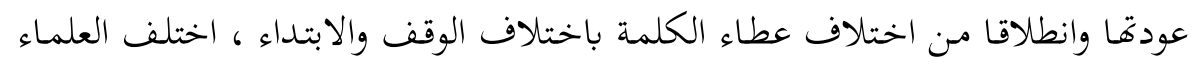

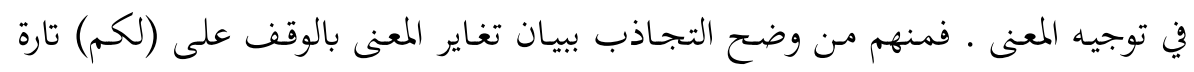

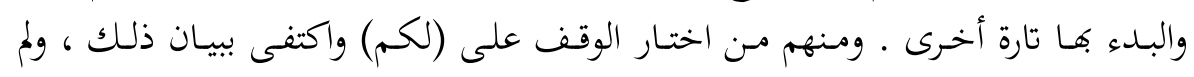

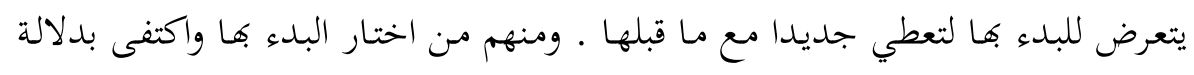

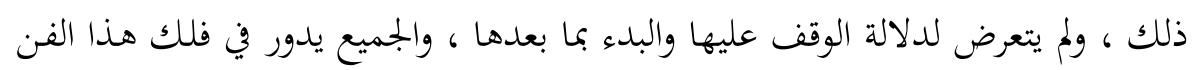

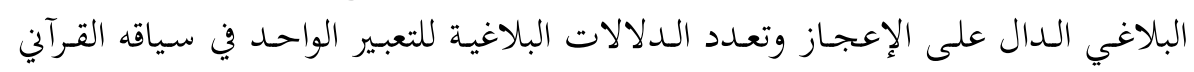

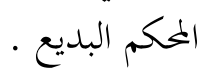

وإذا وجهنا قلمنا ليتبع ذلك عند المفسرين وجدناه يخط لنا سطوراً عن هذه الوجهات

\section{العلامة الشهاب}

نجد مـن العلمـاء الذين بينوا وجهي الدلالة بييان التجـاذب في (لكمم) في تلك الآيـة

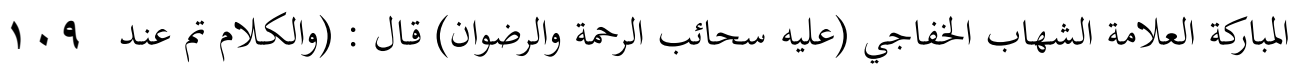

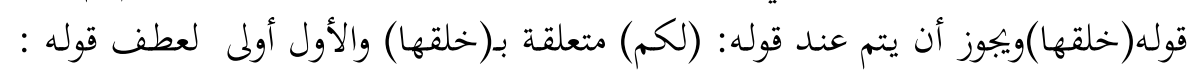

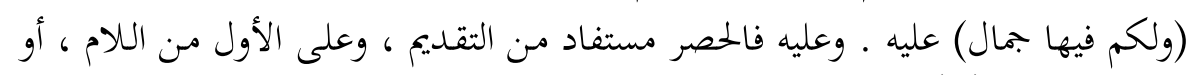

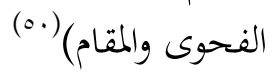

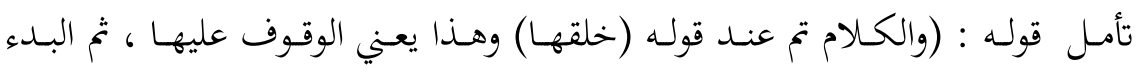

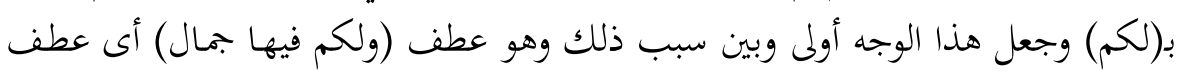

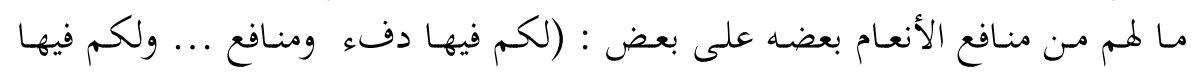

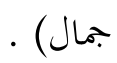

ثم قال مشيراً إلى الوجه الثاني : بقوله : (ويجوز ان يتم عند قوله : (لم متعلقة بخلقها)

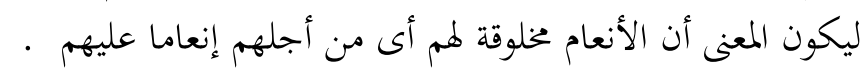
الألوسي

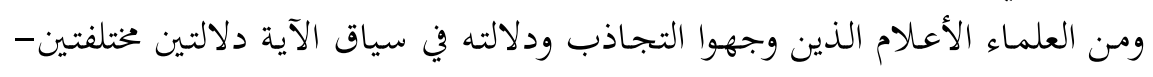

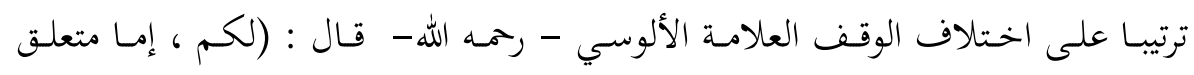

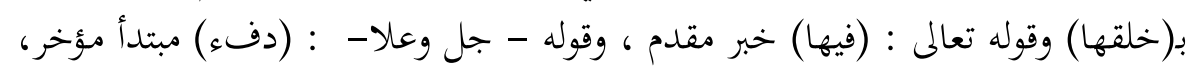


والجملة حال مـن المفعول ، أو الجار والمجرور الأول ، خبر للمبتدأ المذكور ، والثاني متعلق

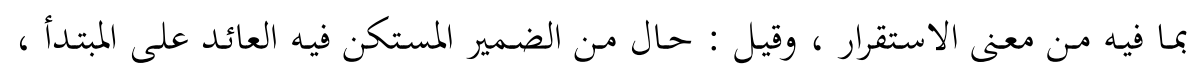

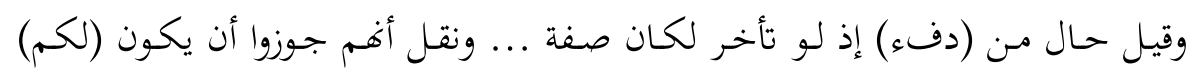

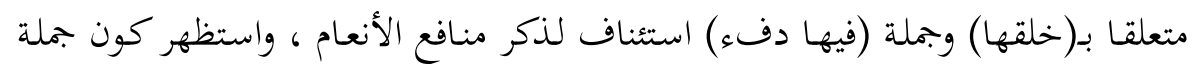

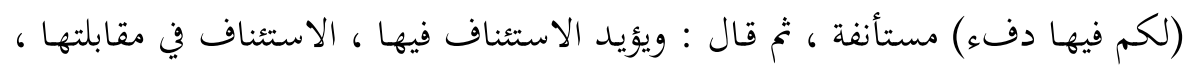

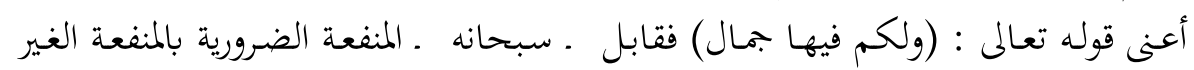

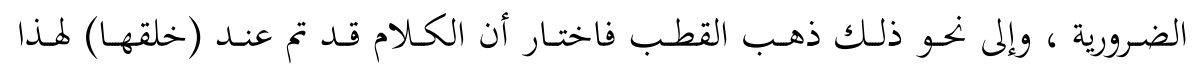

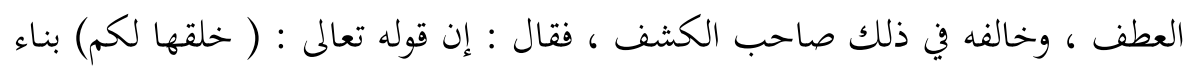

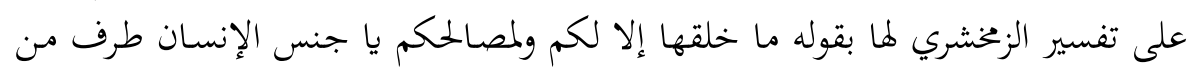

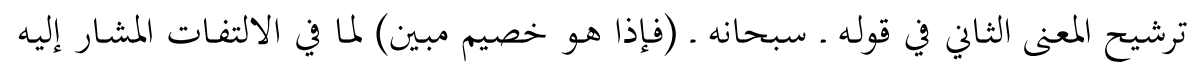

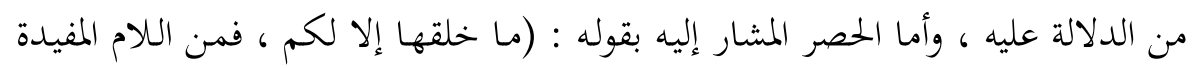

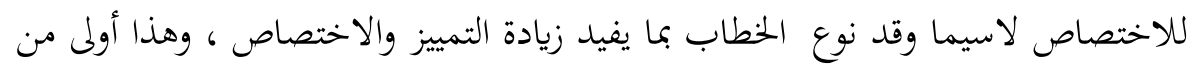

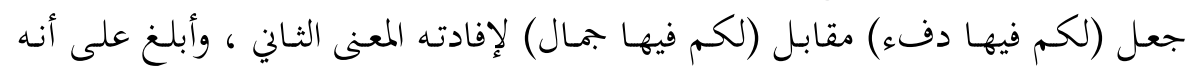

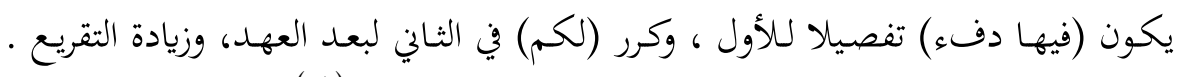

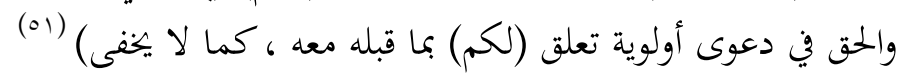

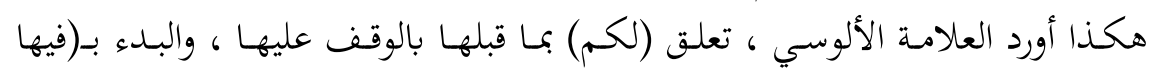

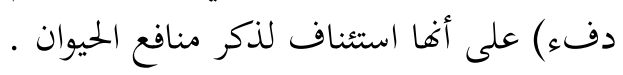

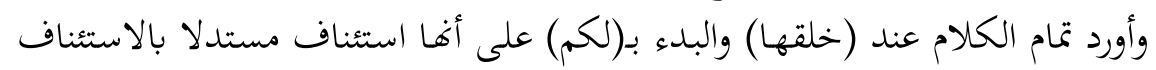

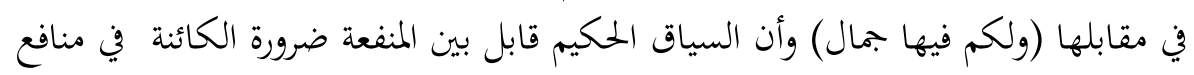

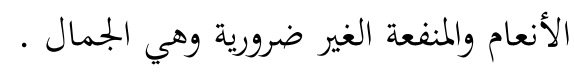

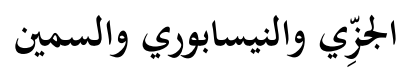

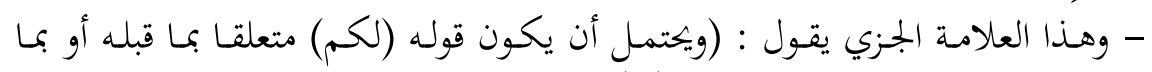

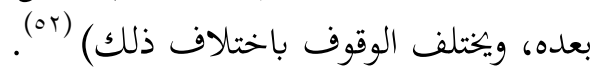
- وممن أشار إلى الوجهين وبين التجاذب في عبافل فيارة موجزة العلامة النيسابوري ، قال:

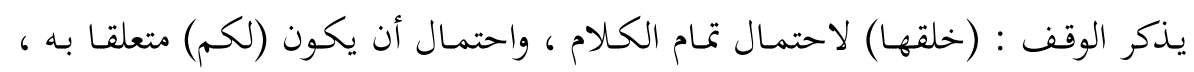

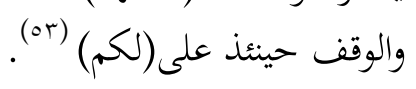

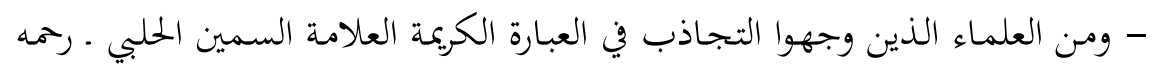

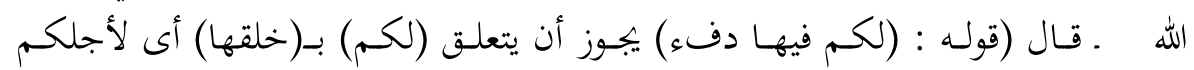

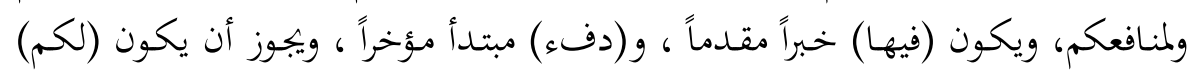


هو الخبر ، و (فيها) متعلق بما تعلق به الخبر ، أو يكون (فيها) حالاً من (دفء) لأنه لو

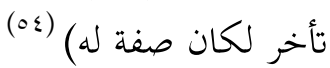

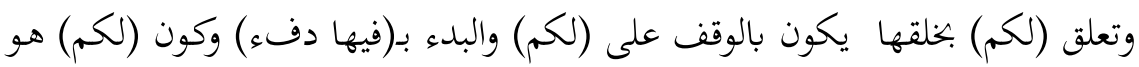
الخبر يكون على الوجه الثاني ، أعني بالوقف على بلى (خلقها) ولئل والبداء بـ(لكم).

\section{العلامة الجممل}

- وأخيراً نرى توجيه دلالة التجاذب الجمل وعلى الوجهين اتباعا للوقف فيما أورده العلامة

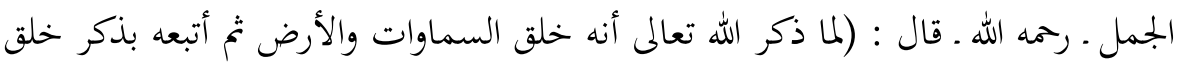

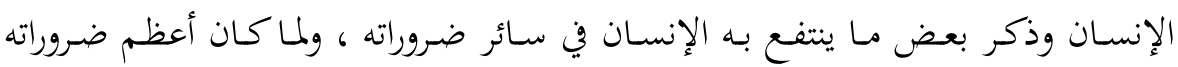

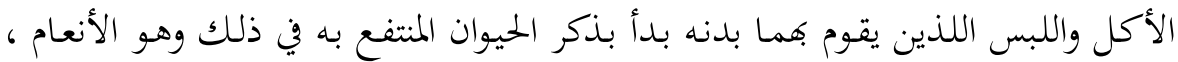

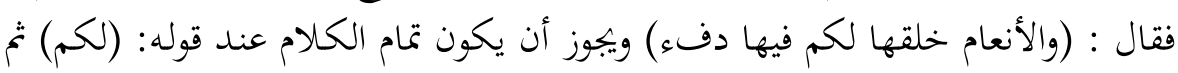

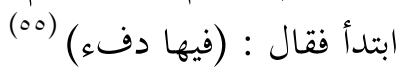

-ومن العلماء الذين اختاروا الوقف على (لكم) واكتفوا بتوجيه المعنى على ذلك العلامة

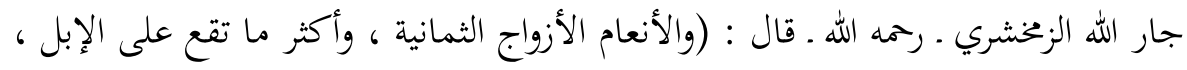

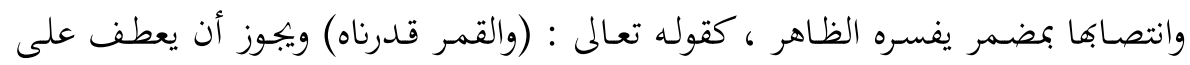

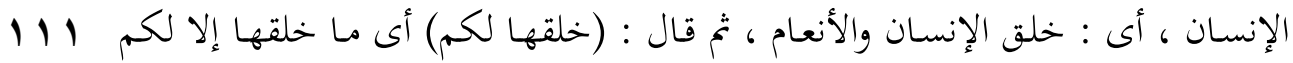

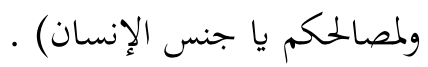

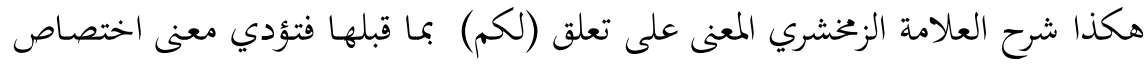

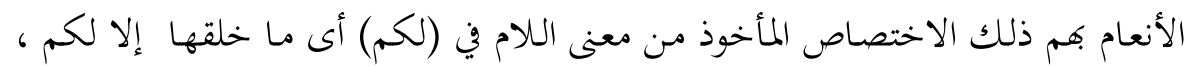

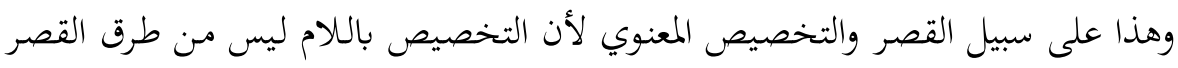

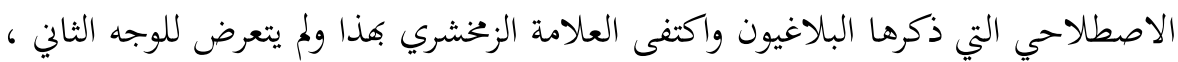

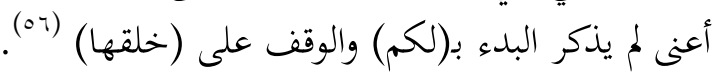
الثوكالي

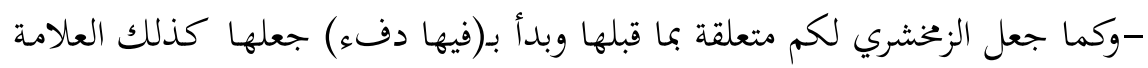

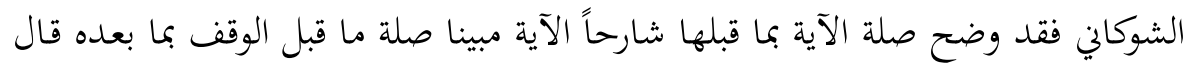

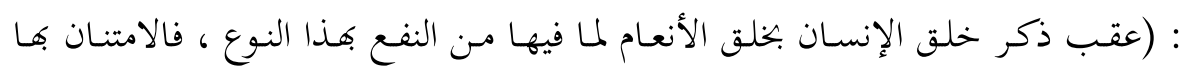

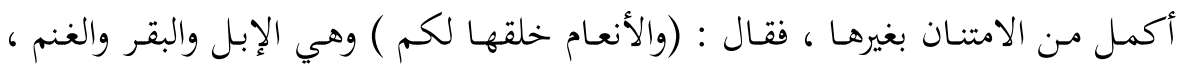

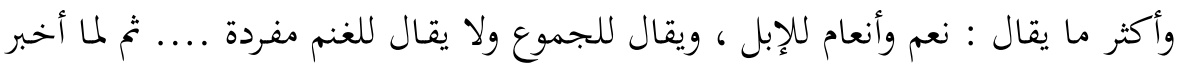

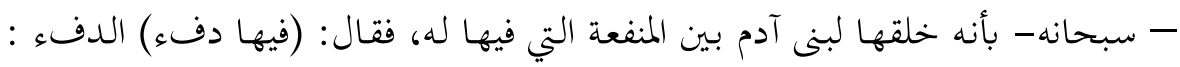




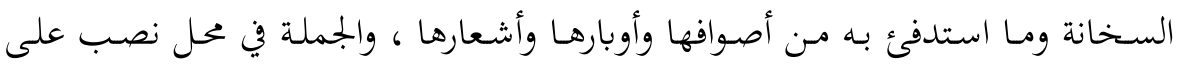

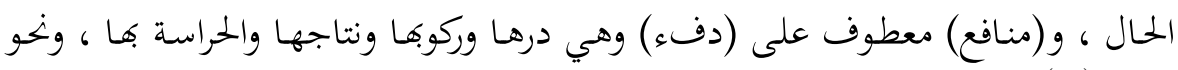
ذلك) (لح)

هكذا وضح بالوقف على (لكم) أن المعنى : أنه خلقها لبنى آدم ، والبدء بـ(فيها دفء)

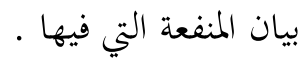
ابن عاشور

-ومن العلماء الذين بينوا المعنى بالوقف على (خلق عانها) والبدء بـ(لكم) العلامة الطاهر

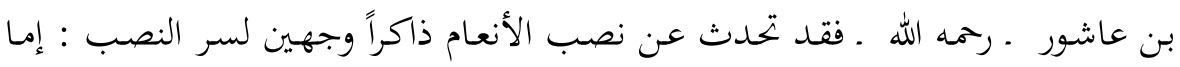

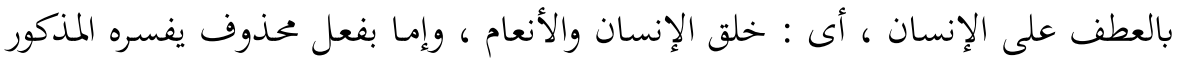

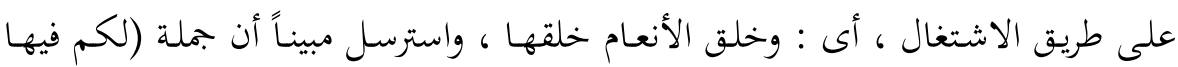

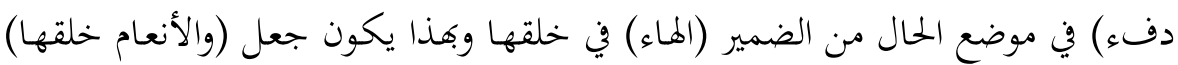

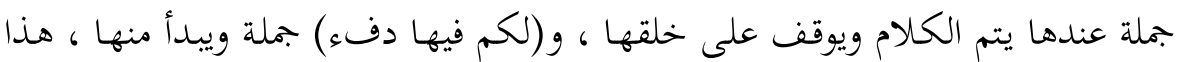

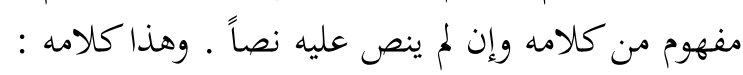

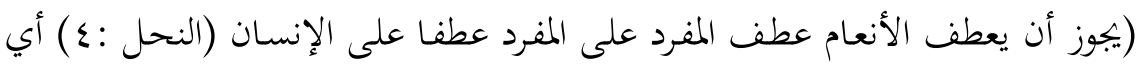

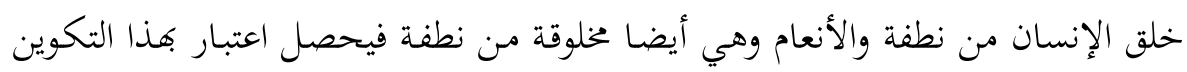

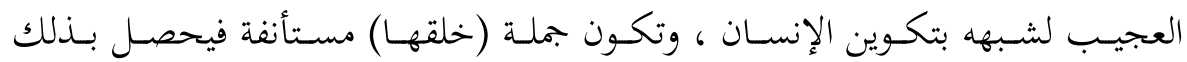
الامتنان. وييجوز أن يكون عطف الجملة على الجملة ، فيكون نصب الأنعام بفعل مضمر يفسره

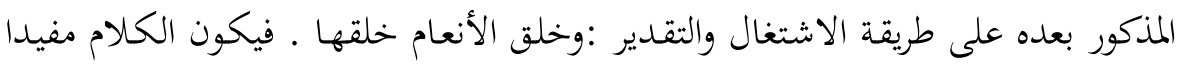

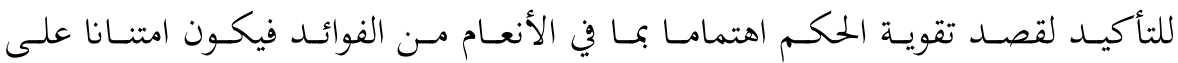

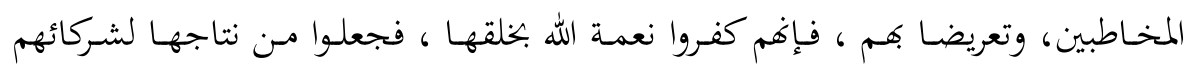

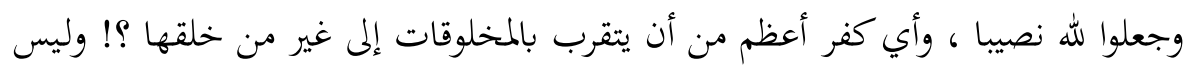

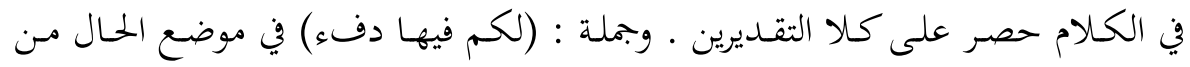

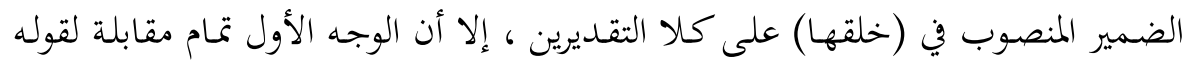

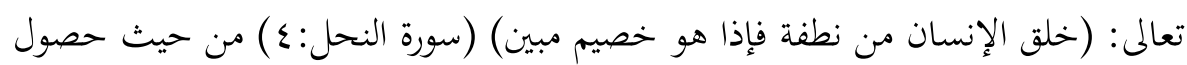

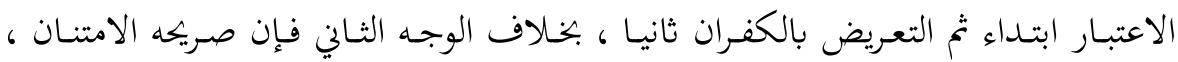

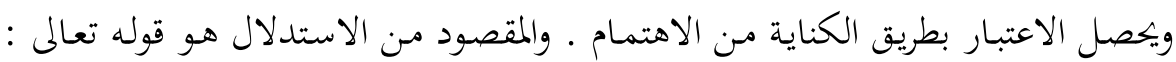

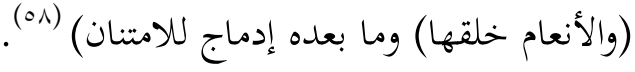




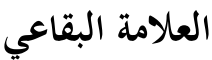

-وممن اختار هذا الوجه في الآية الكريمة أيضاً العلامة برهان الدين البقاعي ـ رحمه الله .

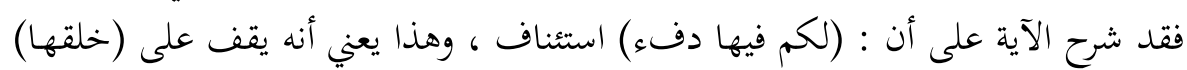

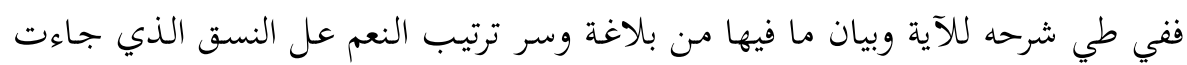

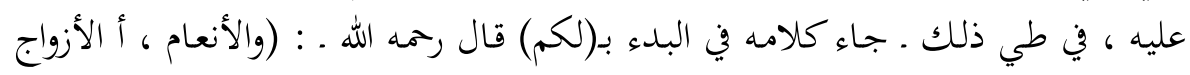

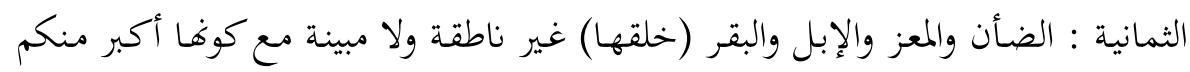
خلقا وأشد قوة

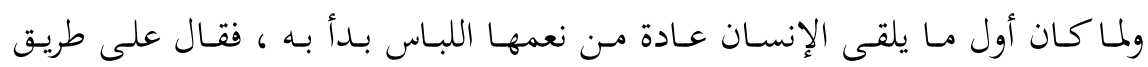

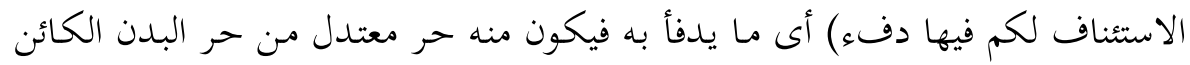

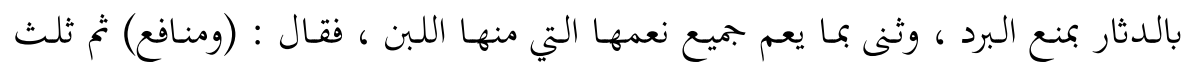

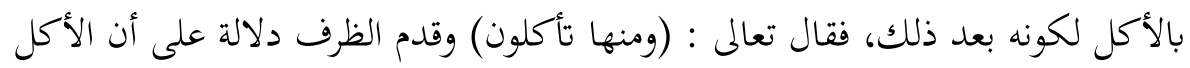

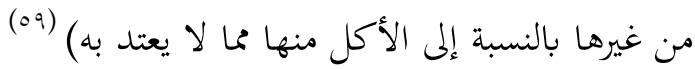

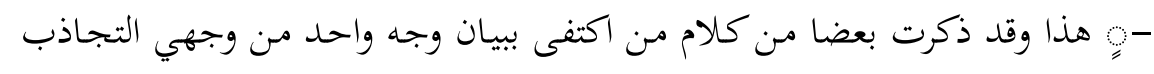

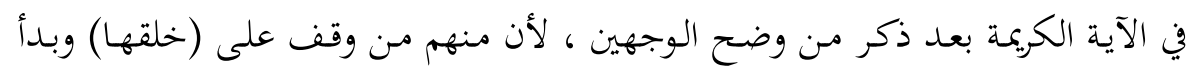

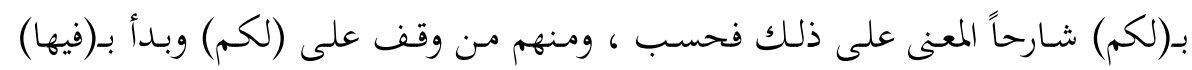

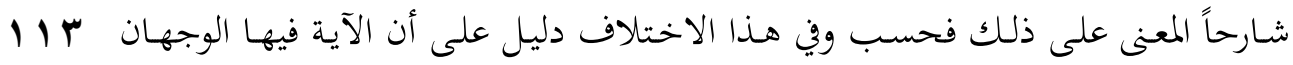

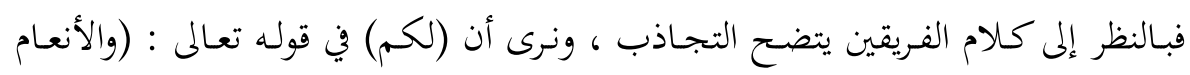

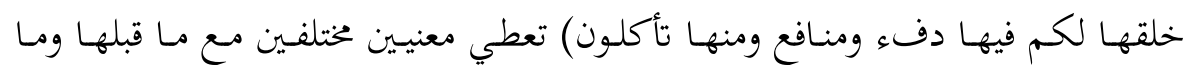




\section{المبحث الرابع : التجاذب في (هم العلدو)}

$$
\text { قال تعالى في شأن المنافقين : }
$$

(وإذا رأيتهم تعجبك أجسامهم وإن يقولوا تسمع لقولمم كأغم خشب مسندة يحسبون

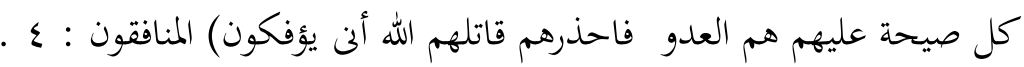
جاءت الآية الكريمة تنتظم سلسلة من الذم للمنافئمين في مطلع سورة المنافقين هؤلاء الكاذبون المخادعون الذين اتخذوا أيماهم جنة ووقاية وصدوا بذلك عن سبيل سيل الله ، فلما ضلوا أصلهم الله وطبع على قلوبكم .

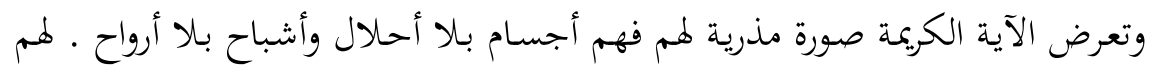

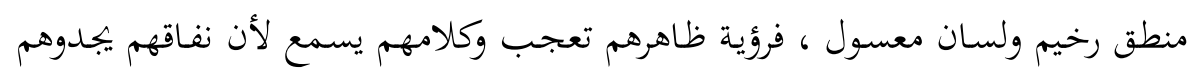

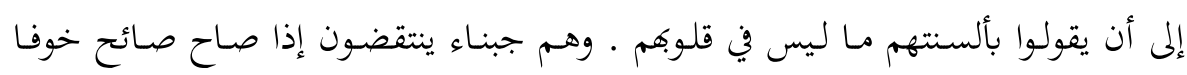

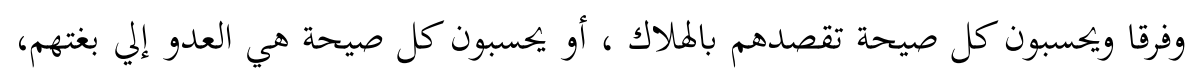

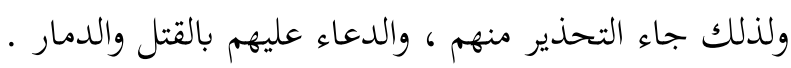

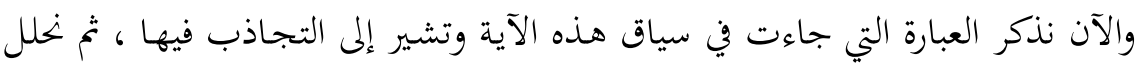
ذلك مستنطقين السياق مناقشين كلام العلماء .

والعبارة هي: (يحسبون كل صيحة عليهم هم العدو فاحذرهم قاتلهم الله)

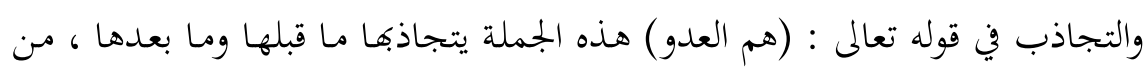

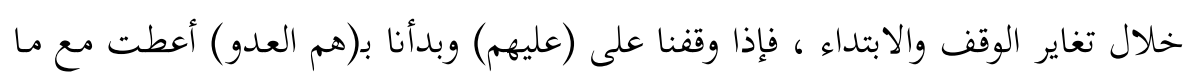

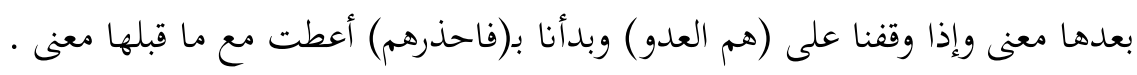

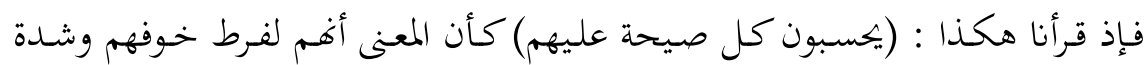

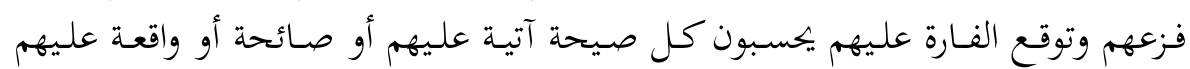

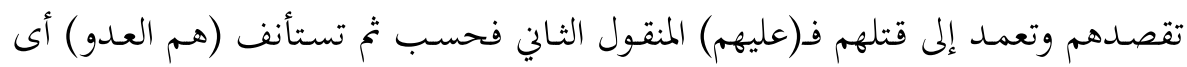

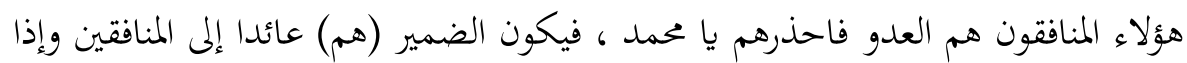

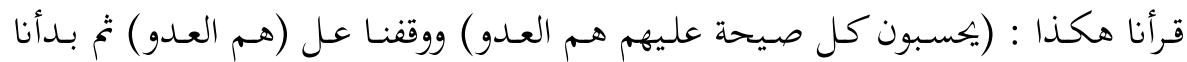

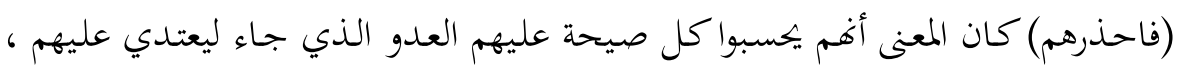

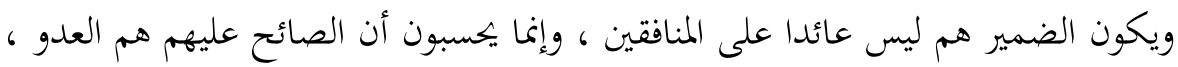

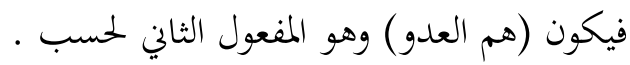
والسياق الحكيم يتسع لهاتين الدلالتين المختلفتين باختلاف وهول الوقف والابتداء . 
وهنا نعرض لما تتبعناه من كلام أئمة المفسرين نستوضح من خلاله دلالة التجاذب وأثره

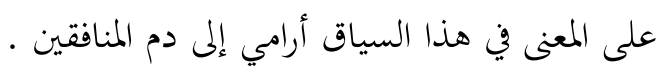

\section{البيضاوي وتعليق الثهاب}

فهذا العلامة البيضاوي -رحمه الله- يقول : (يحسبون كل صيحة عليهم أى واقعة عليهم

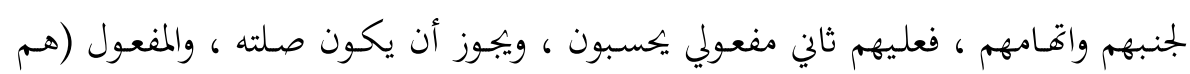

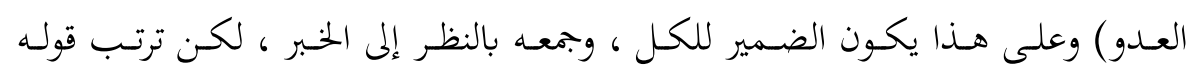

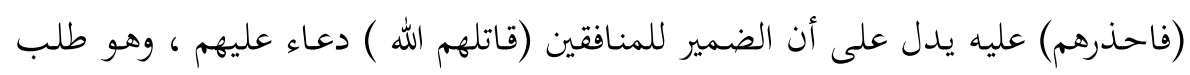

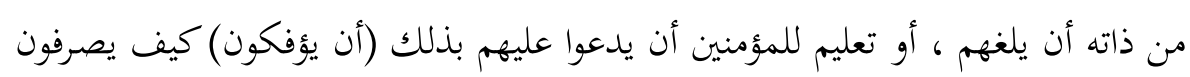

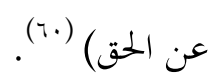
هكذا ذكر العلامة الشهاب الوجهين : الوقف على (عليهم) على أفها المفعول الثاني

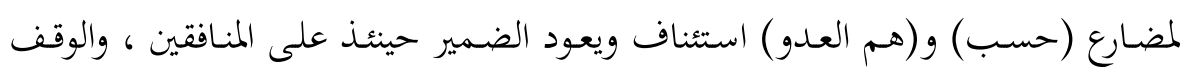

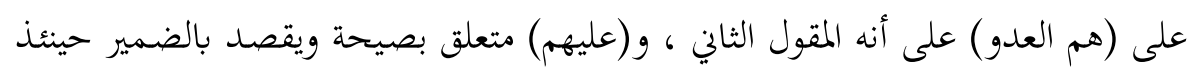
العدو الذي يحذرون غارته عليهم .

ومع أنه ذكر الوجهين كنه اختار الوقوف على (عليهم) مستدلا بالسياق ، به فئ(العدو) 110

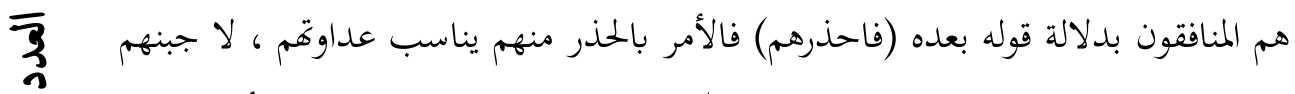

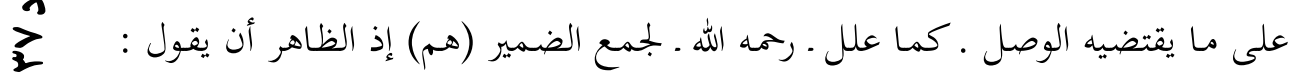

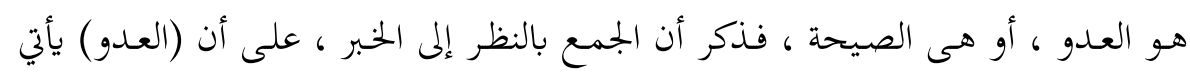

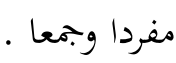

ـ وقد وضح العلامة الشهاب الخفاجي ما قاله العلامة البيضاوي ووافقه فيما قال ، قال

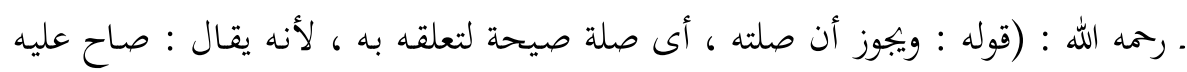

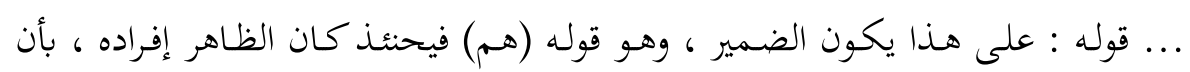

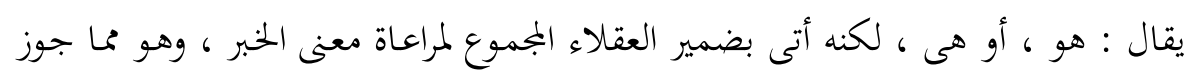

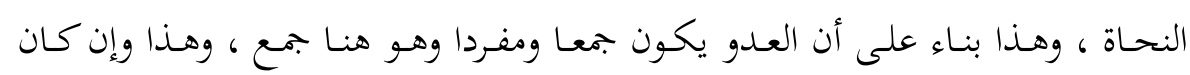

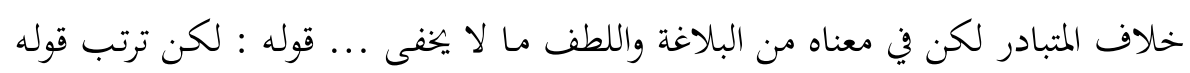

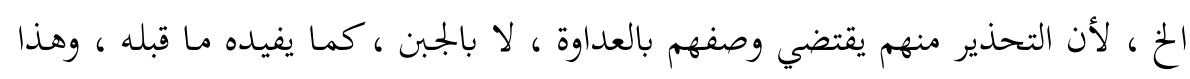


الضمير للمنافقين بلا شبهة ، فبإذا عاد مـا قبله على العدو لزم تفكيك الضمائر ، وفي اتصال قوله : للمنافقين ، بقوله : قاتلهم الله إيهام لطيف لا يخفى لطفه ، قوله : طلب ،

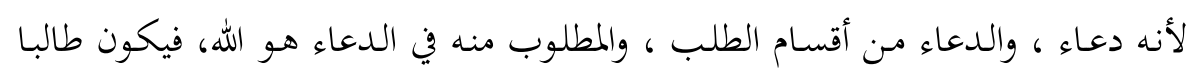

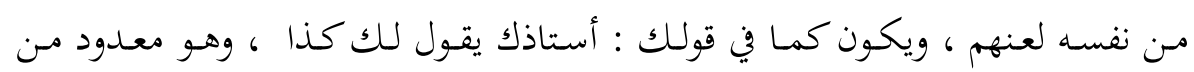

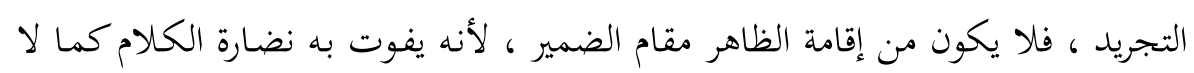

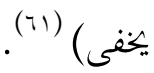

هذا تعليق العلامة الشهاب على كملام البيضاوي ، وقد وافقه بان جعل (هم العدو)

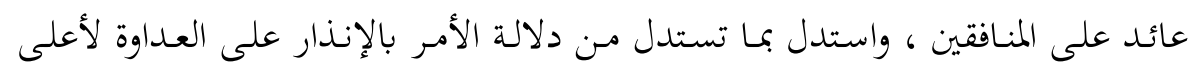

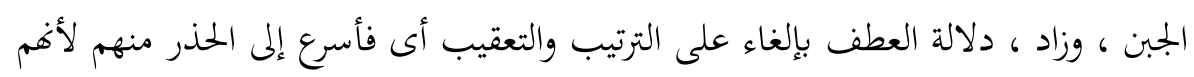

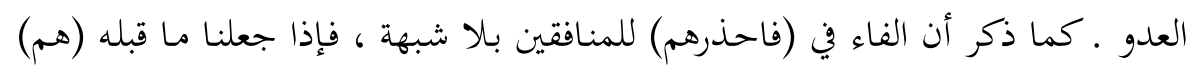

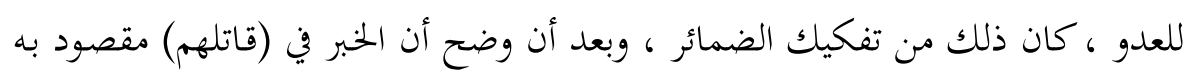

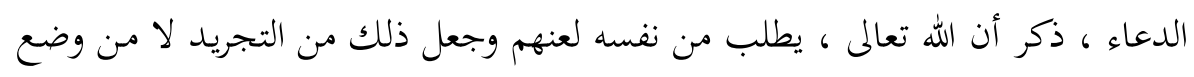

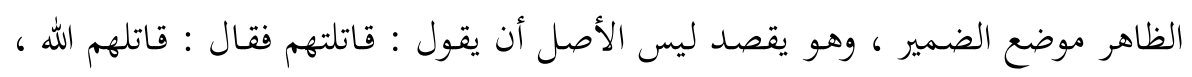

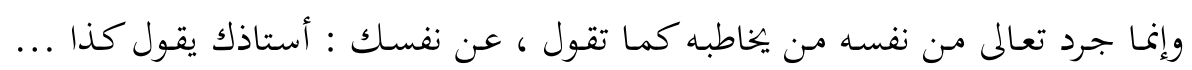

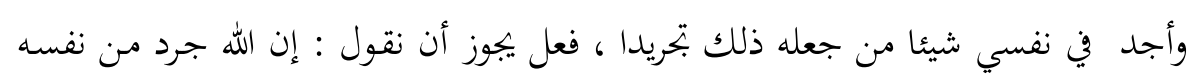

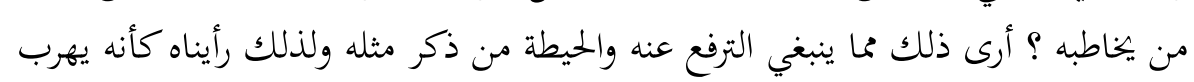

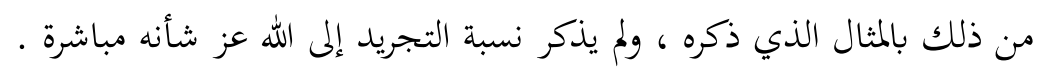

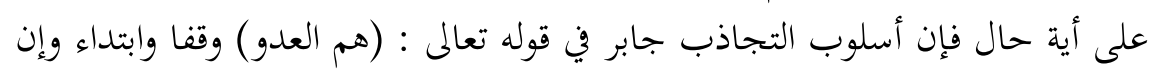
قوى أحد الوجهين على الآخر لدلالة السياق عليه .

\section{الزمخشري والسمين}

ـ أما العلامة جار الله الزخشري ـ رحمه الله . فبين كيف بتحاذب (هم العدو ) ما قبلها وما

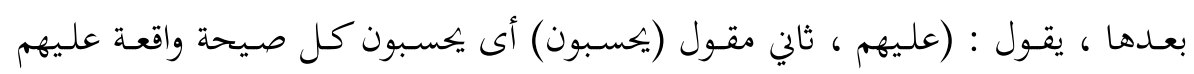

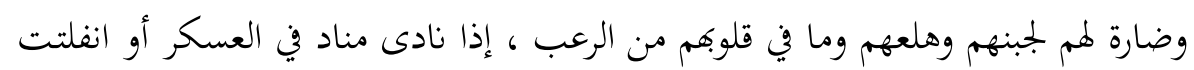

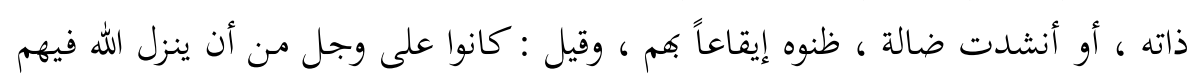

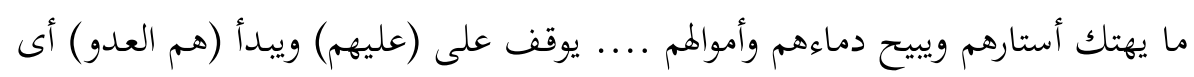

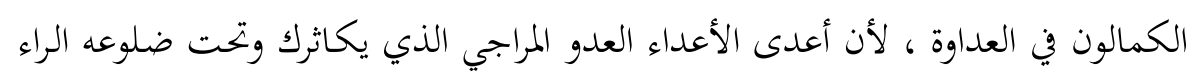

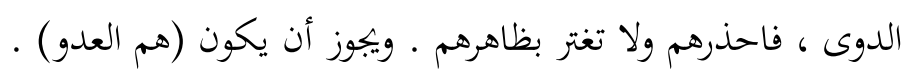


المفعول الثاني ، كما لو طرحت الضمير ، فإن قلت : حقـه أن يقال :هي العدو .

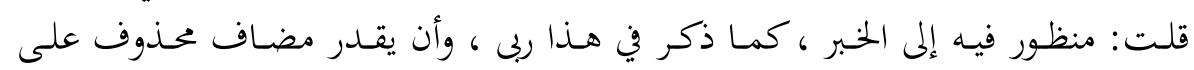

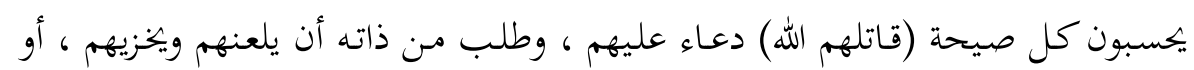

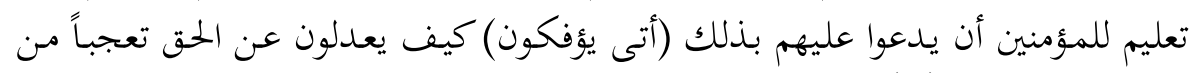

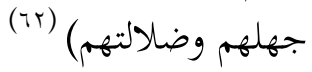

كما رأيت : ذكر العلامة الزخشري التجاذب في (هم العدو) فبالوقوف على (عليهم)

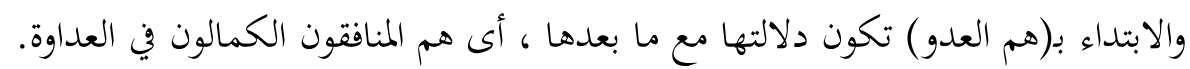

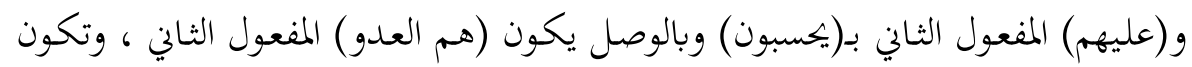

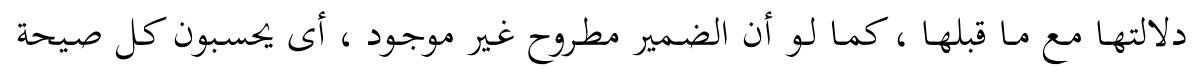
العدو . دون.

ـ وكما وضـح الزخشـري التجـاذب وضحه كـذلك العلامـة السمين ، فقـال: (قولهه :

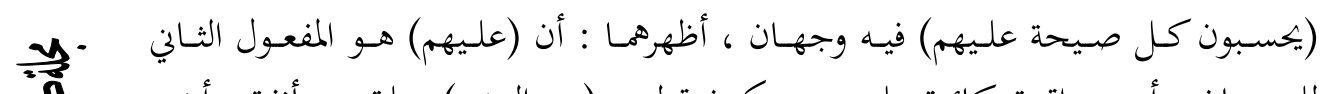

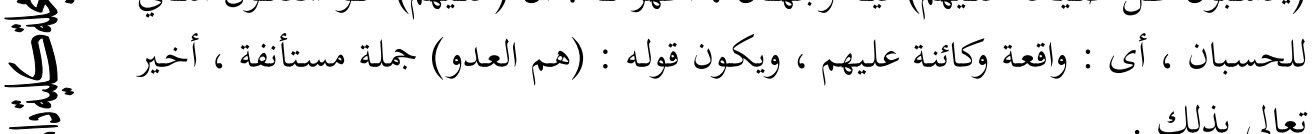

والثاني : أن يكون (عليهم) متعلقاً بصيحة ، و (هم العدو) الجملة في موضع المفعول

دلالتا التجاذب واضحتان في كلام العلامة السمين فقـد أوجز وأجـاد وأفاد ، فـ(هم

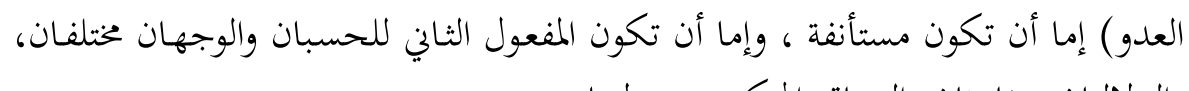

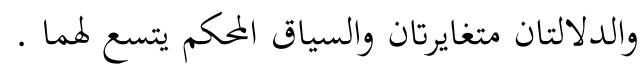
القرطبيّ

- ومن العلماء الذين وضحوا التجاذب في هذا الموضع العلامة القرطبي ـ رحمه الله عليه .

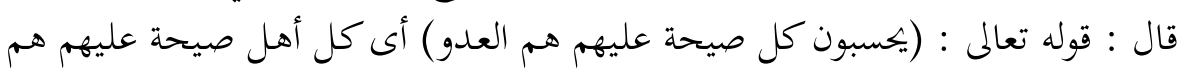

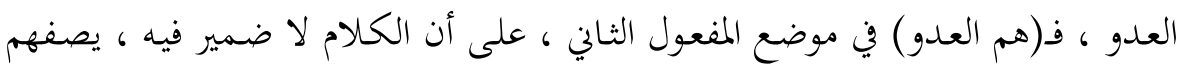

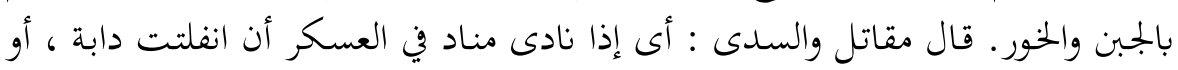

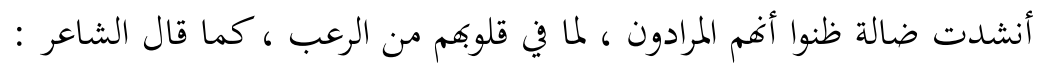

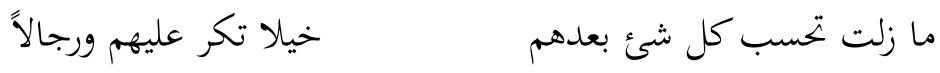


وقيل : (يحسبون كل صيحة عليهم هم العدو) كلام ضميره فيه لا يفتقر إلى ما بعد،

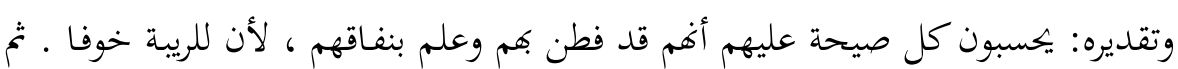

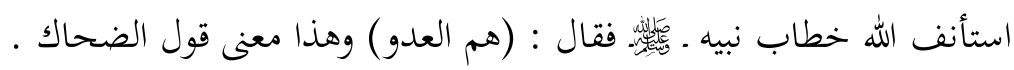

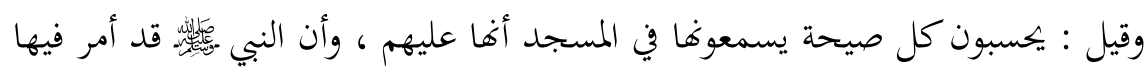

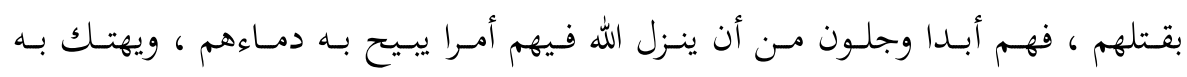

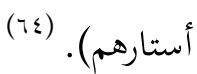

هكذا وضح العلامة القرطبي الوجهين وقفاً وابتداءً وشرح أن بالوقف على (عليهم)

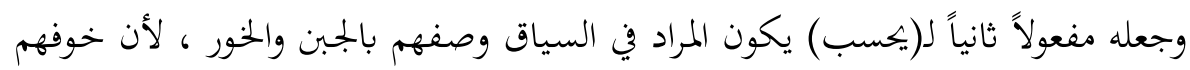

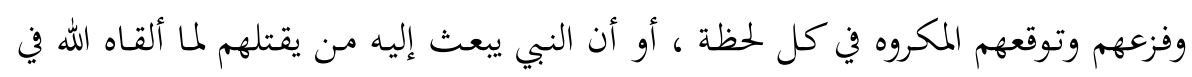

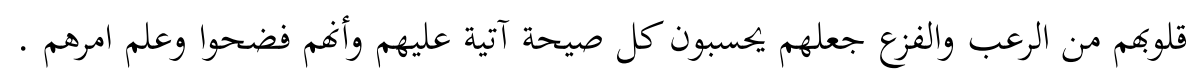
الألوسي وأبو السعود

ودعماً لما ذكرناه مـ وضوح التجاذب وتغاير الدلالة في هذه العبارة الكريمة ، نذكر التهر

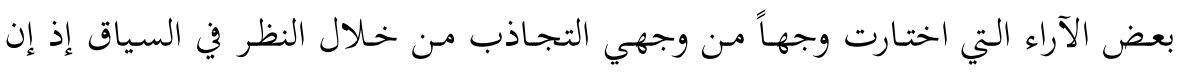

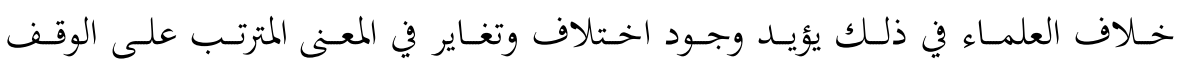
والابتداء.

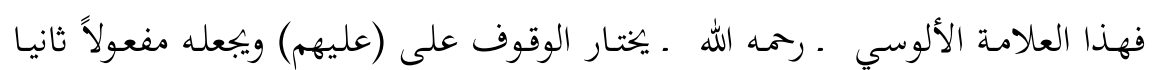

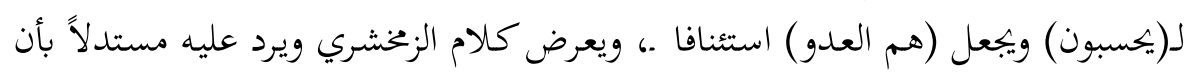

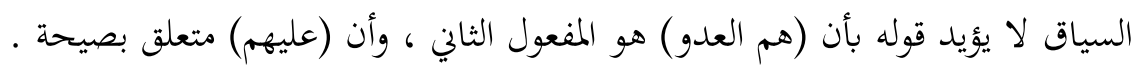
وهذا كلامه ـ طيب الله ثراه ـ.

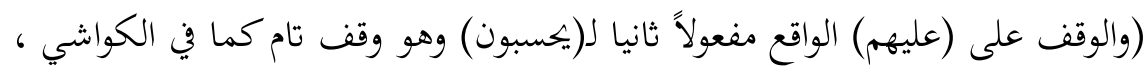

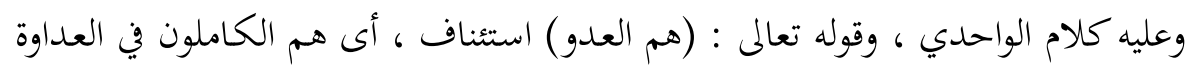

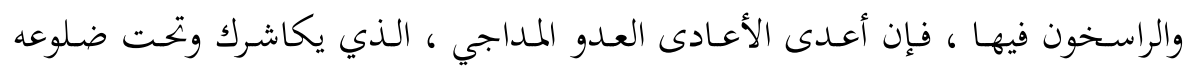

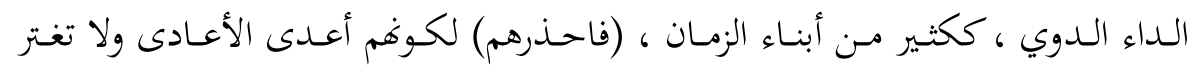

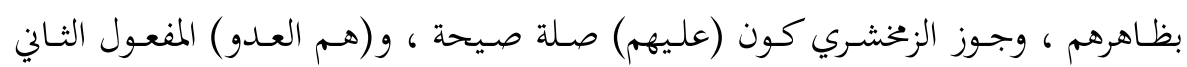

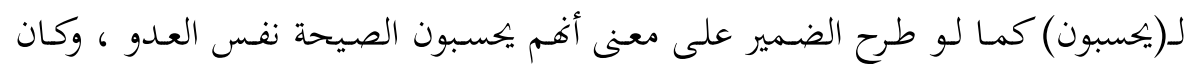

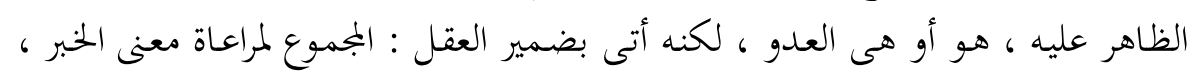

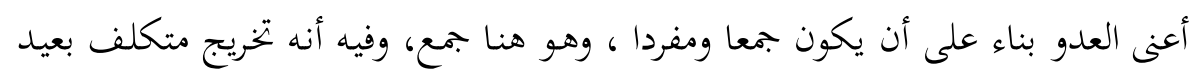


جدا لا حاجة إليه ، وإن كان المعنى عليه لا يخلو من بلاغة ولطف ، ومع ذلك لا يساعد

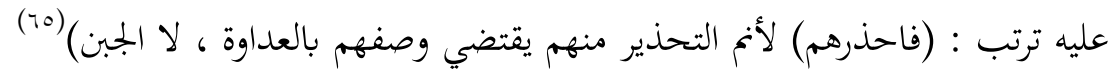

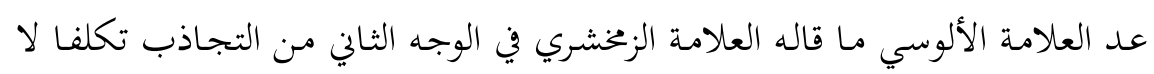

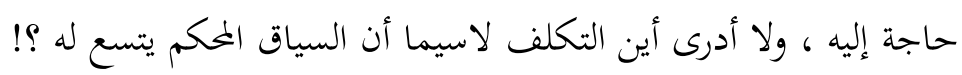

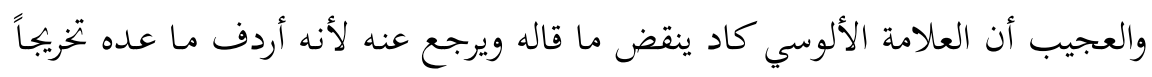

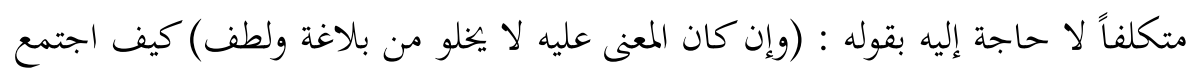

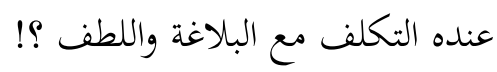
تم عاد سريعا كأنه أحس بالتذبذب في الرأى ـ عاد سريعاً ـ يدلل لاختياره الوقوف على العلى

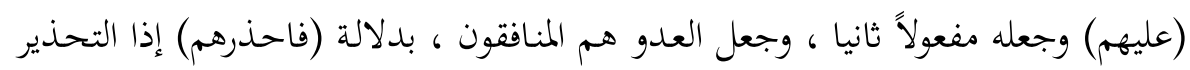

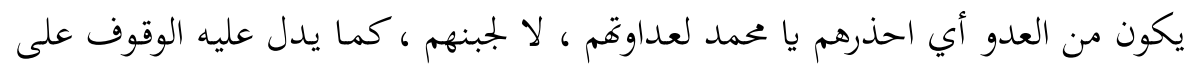

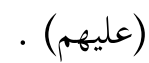

- وكما رأى العلامة الألوسي رأى العلامة أبو السعود وتعقب الزخشري كما تعقبه، قال

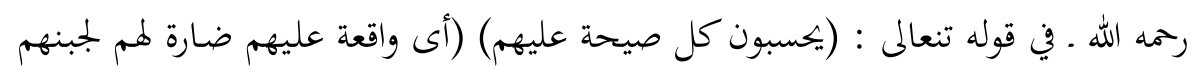

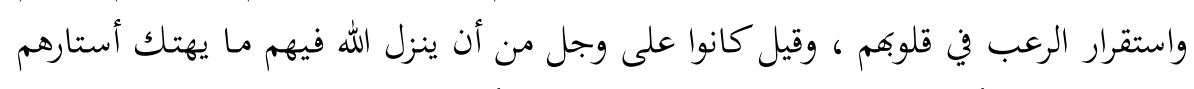

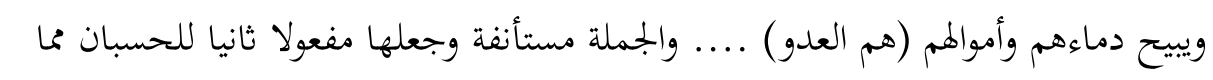

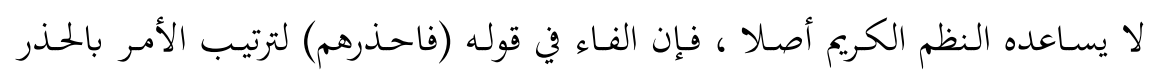

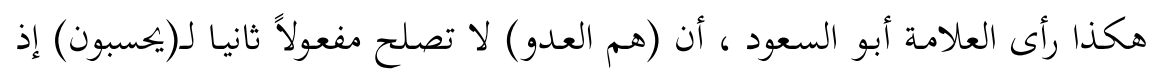

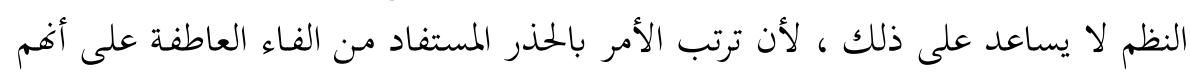

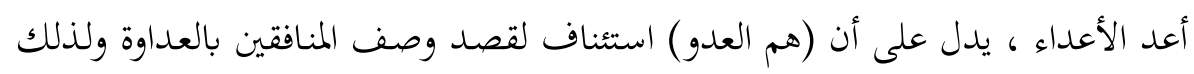

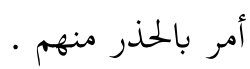
الطاهر ابن عاشور

- أما العلامة الطاهر بن عاشور ـرحمه الله ـ فقد اختار الوقف على (عليهم) وأهـا

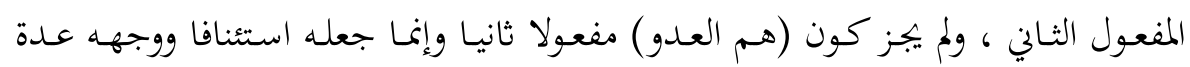

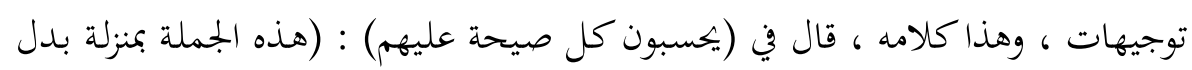

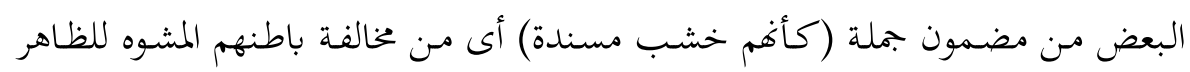

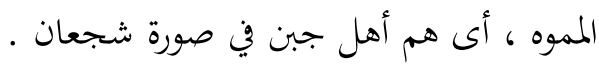


وهذا مـن جملة مـا فضحته هذه السورة مـن دخائلهم ومطاوي نفوسهم كما تقدم في الآيات السابقة وإن اختلفت مواقعها من تقنن أساليب النظم فهي مشتركة في التنبيه على دمانى

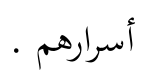

والصيحة : المرة من الصياح ، أى هم لسوء ما يضمرونه للمسلمين من العداوة لا يزالون يتوجسون خيفة من أن ينكشف أمرهم عند المسلمين فهم في خوف وهل وهلع إذا سمعوا صيحة إنمرونه

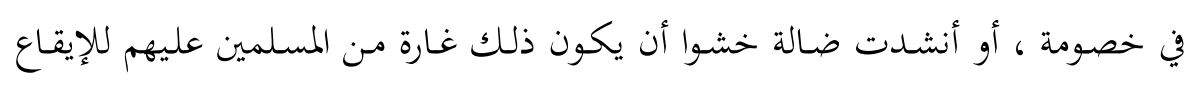

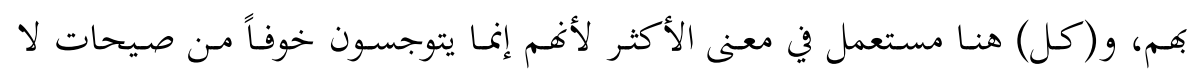
يعلمون أسباهما .... وقوله : (عليهم) ظرف مستقر هو المفعول الثاني لفعل (يحسبون) وليس متعلقا ب(صيحة) . (هم العدو فاحذرهم) يجوز أن تكون استئنافاً بيانيا ناشئا عن جملة (يحسبون كل صيحة

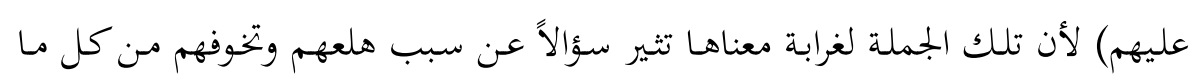

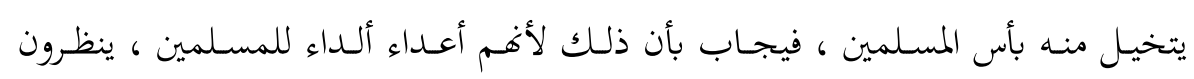

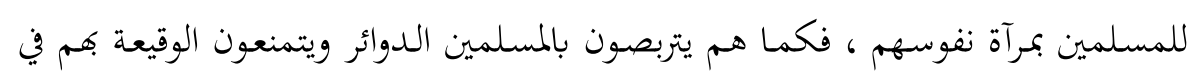
حين يظهرون لهم المودة كذلك يظنون بالمسلمين التربص بهم ، وإضمار البطش بهم ويجموز

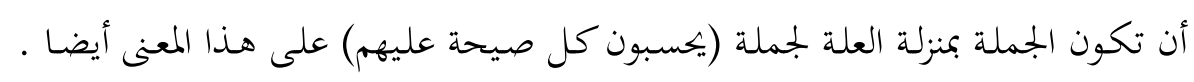

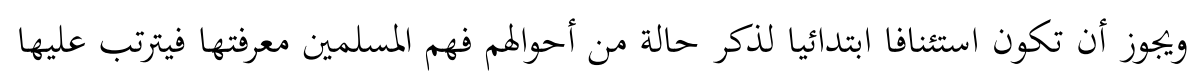
تفريع واحذرهم وعلى كل التقارير فنظم الكلام واف بالغرض من فضح دخائلهم .

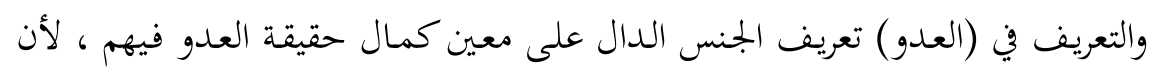

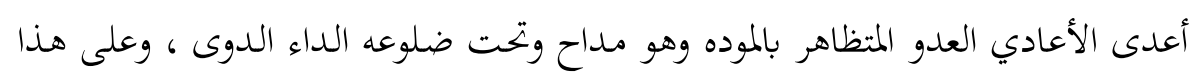

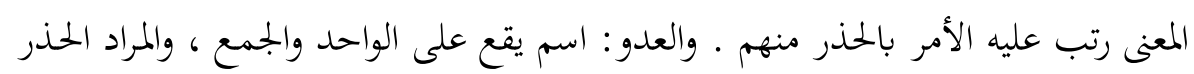

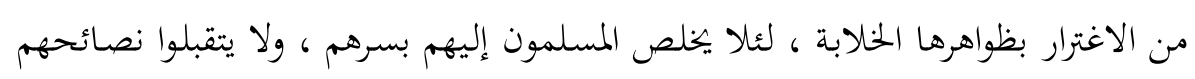
خشية المكائد) (TV) أبى العلامة ابن عاشور أن يجعل (هم العدو) مفعولا ثانيا ، وجعل (هم العدو) مقصورا

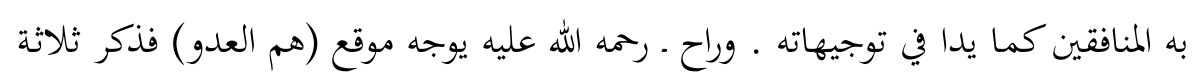

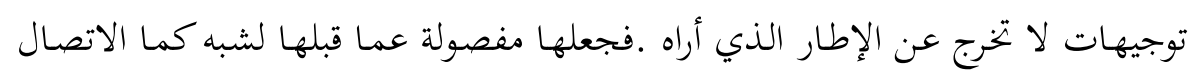


(آ(الاستئناف البياني) فهي جواب عن سؤال أثثرته الجملة السابقة.

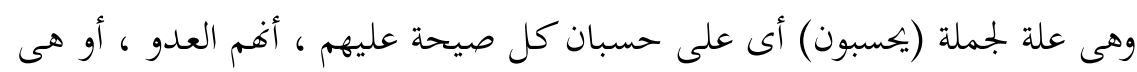

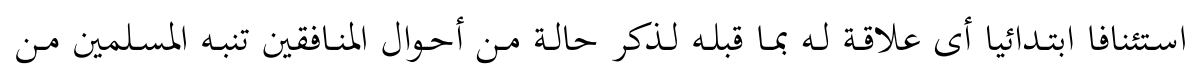

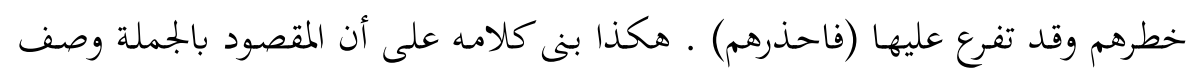

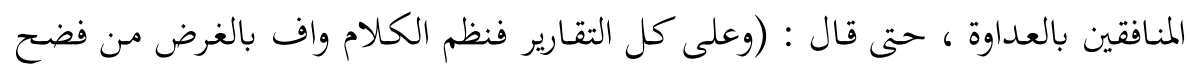

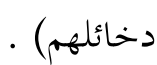

\section{العلامة الرازي}

وأخيرا نرى من أعلام المفسرين العلامة الرازي ينص على وجه واحد ، ولم يشر إلى الوجه

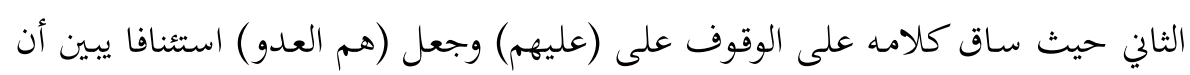

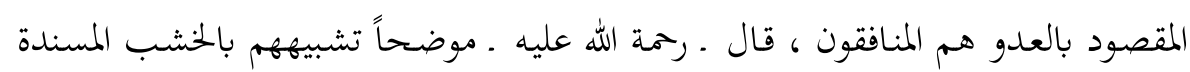
عاطفا بـ(ث) الحديث عن هذه العبارة . (والخشب لا تعقل ولا تفهم ، فكذلك أهل النفاق كأفم في ترك التفهم والاستبصار

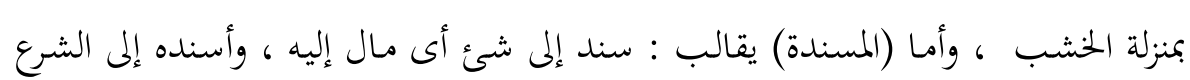

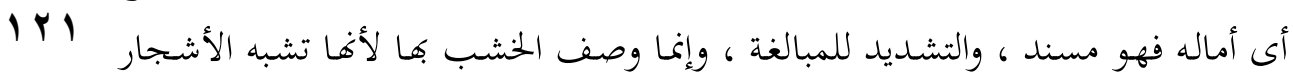

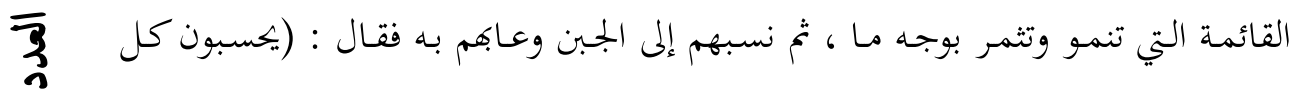
$\geq$ صيحة عليهم هم العدو ) وقال مقاتل: إذا نادى مناد في العسكر وانفلتت دابة ، أو نشدت ضالة مثلا ظنوا أفهم يرادون بذلك لما في قلوبهم من الرعب وذلك لأفهم على وجل من أن أن يهتك الله أستارهم

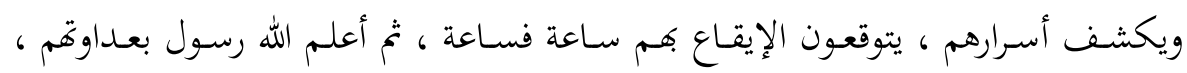

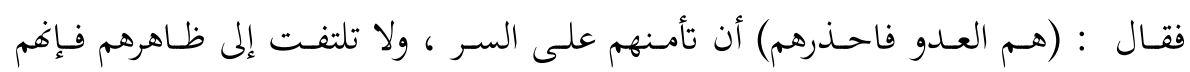

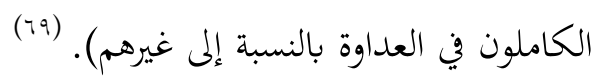

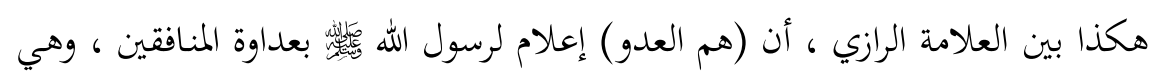

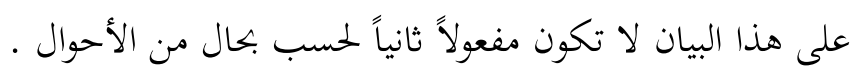
ما أميل إليه وبعد هذه المحاورة والمناقشة لكالام العلماء في بيان التجاذب ، في العبارة القرآنية المباركة، 
أقول : وضح من كلام العلماء أن (هم العدو) يتجاذبه ما قبله وما بعده ، غير أنني وإن

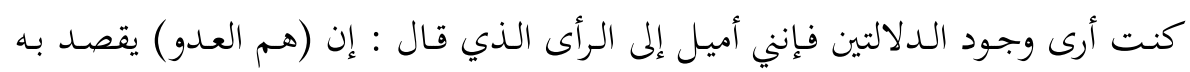

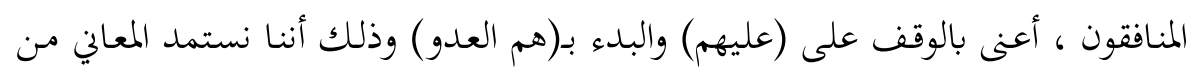

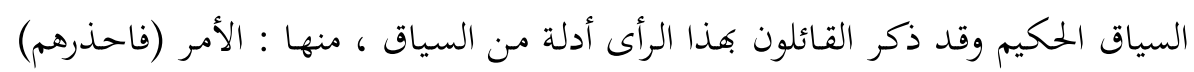

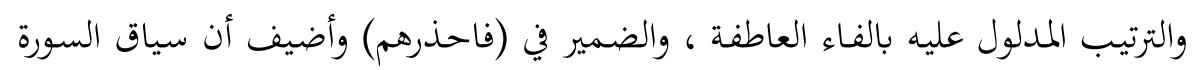

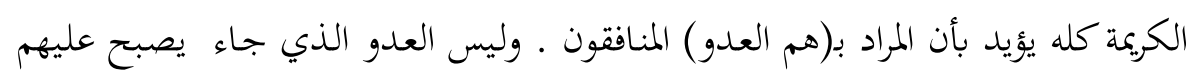
عندما نقف عليها ونجعلها مفعولا ثانيا لحسب . فمنذ بدأت السورة بدأت بذكرهم وذمهم وتكذيب شهادهاتهم (إذا جاءك المنافقون)

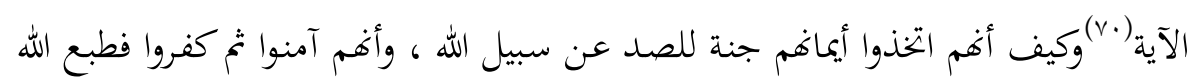

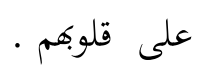

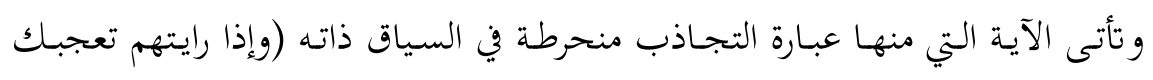

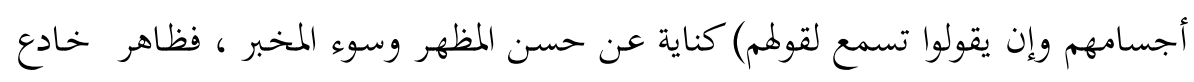

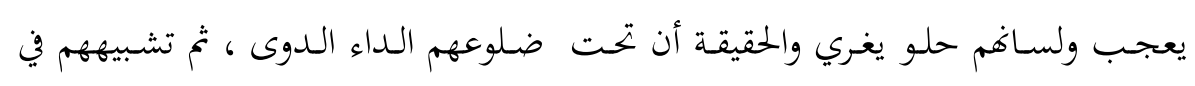

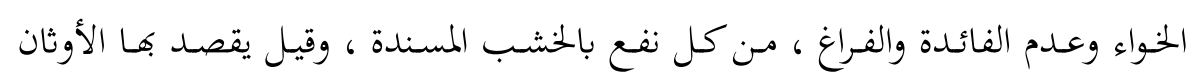

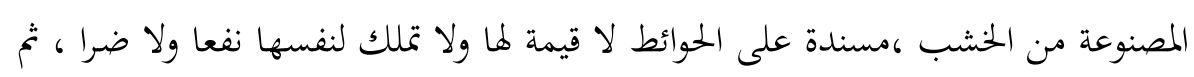

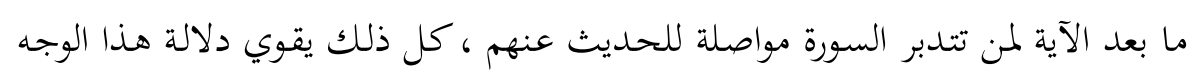
من وجهي التجاذب في العبارة الكريمة . ونورد أخيرا ما يؤيد ذلك من أن الوصف للمنافقين ـ ما ذكره الزخشري ـ رحمه الله ـ في

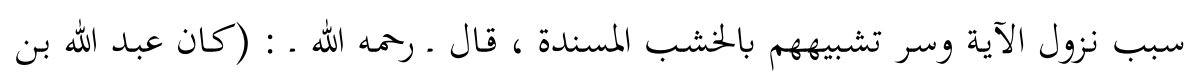

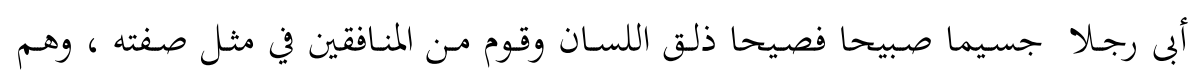

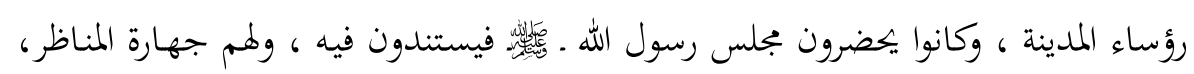

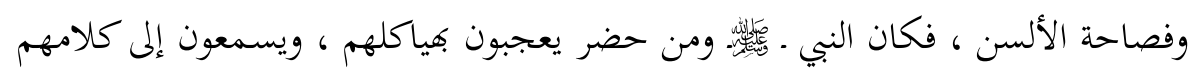

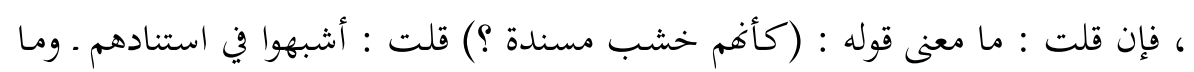

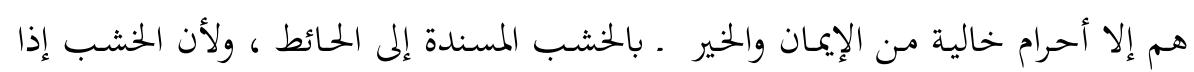

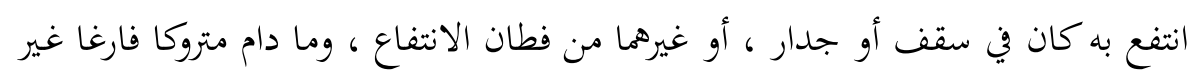


منتفع به أسند إلى الحائط ، فشبهوا به في عدم الانتفاع ـ ويجوز أن يراد بالخشب المسندة:

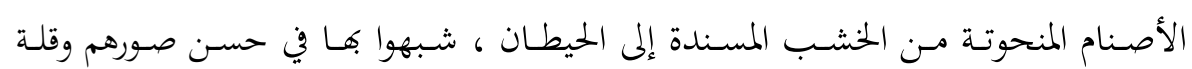

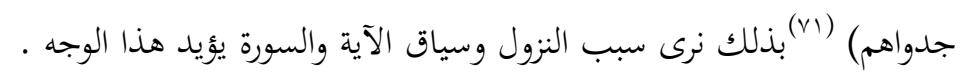

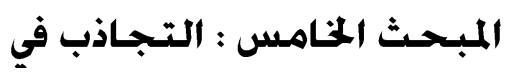

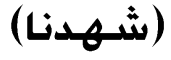

قال تعالى : (وإذ أخذ ربك من بنى آدم من ظهورهم ذريتهم وأشهدهم على أنفسهم

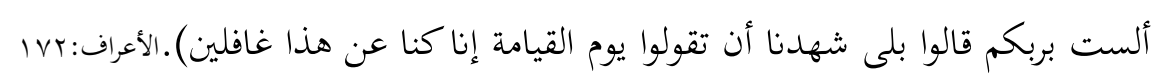

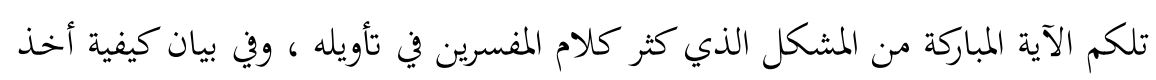

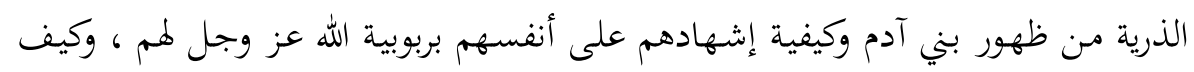

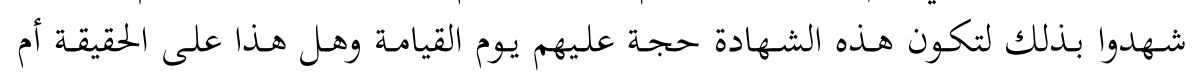

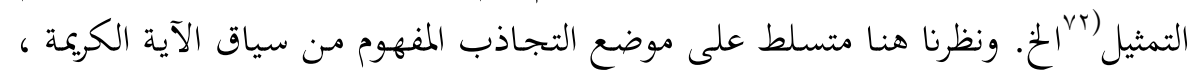

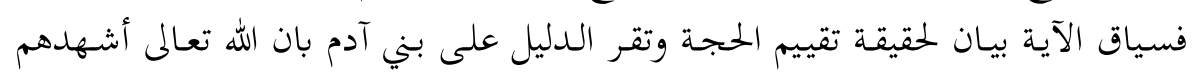

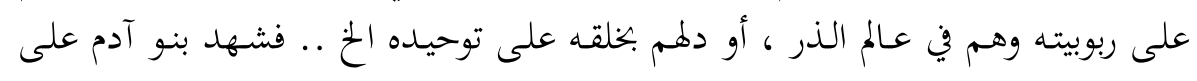

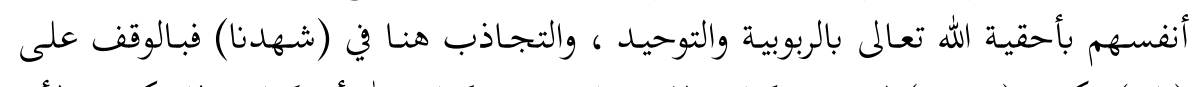

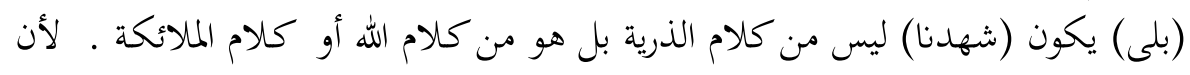

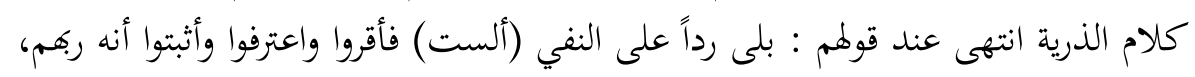

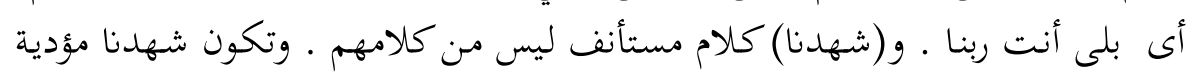
مع ما بعدها.

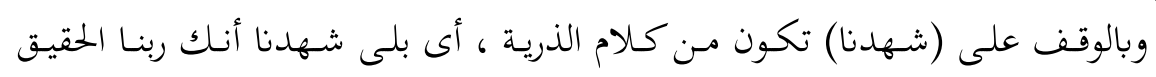

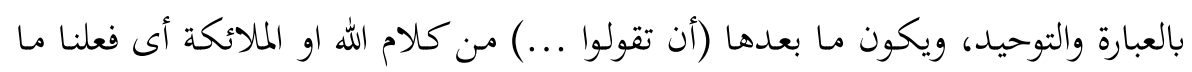

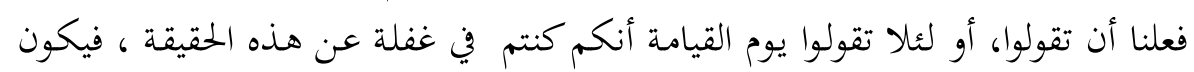

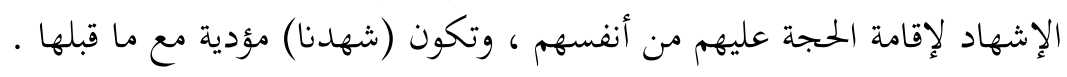

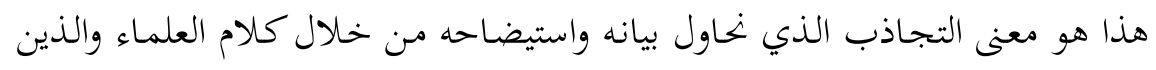

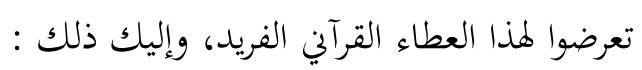

\section{الرازي والسمين}

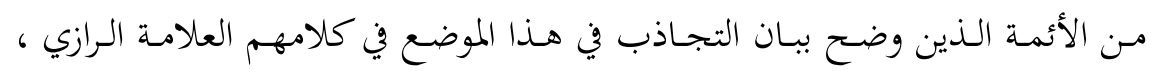

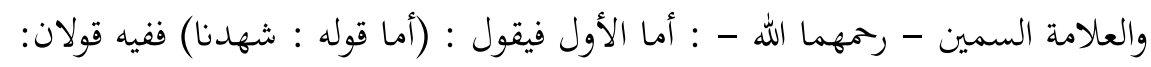

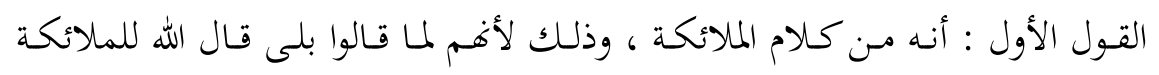


اشهدوا فقالوا شهدنا ، وعلى هذا القول يحسن الوقف على قوله : (قالوا بلى) لأن كلام

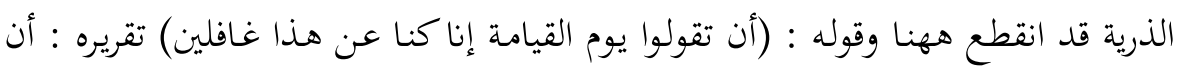

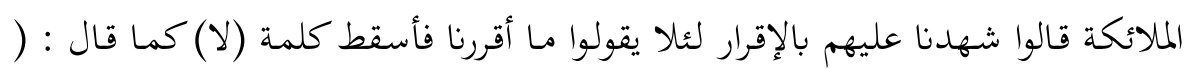

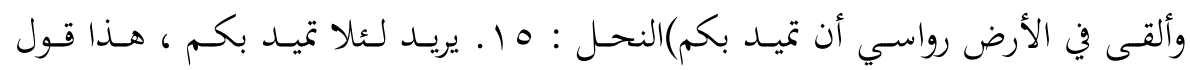
الكوفيين ، وعند البصريين تقريره : شهدناكراهة أن يقولوا .

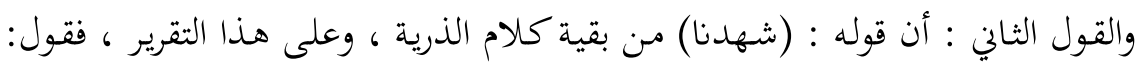

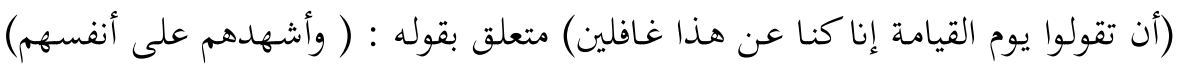

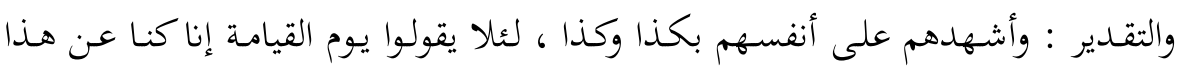

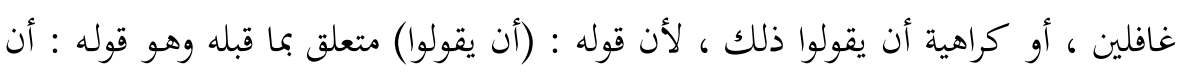

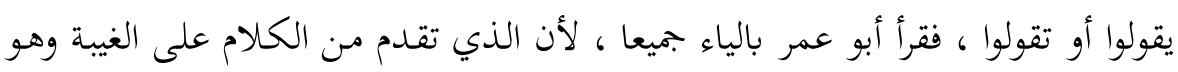

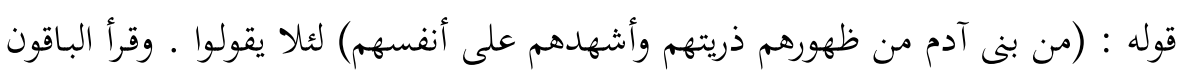

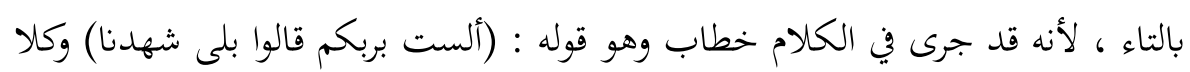

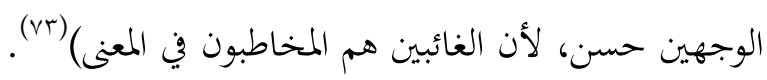
هكذا وضح التجاذب في (شهدنا) في كلام العلامة الفخر الرازي ــ رحمه الله ـ رابطا

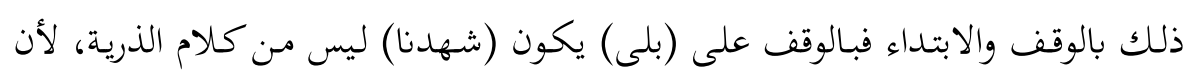

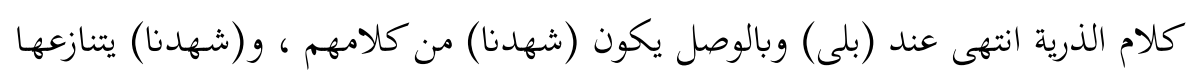
费

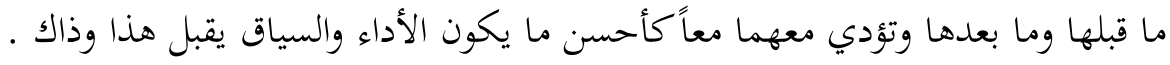
- وأما الثاني (العلامة السمين) فقال : (قوله : (بلى) جواب لقوله : (ألست) ......

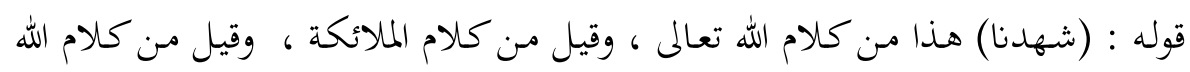

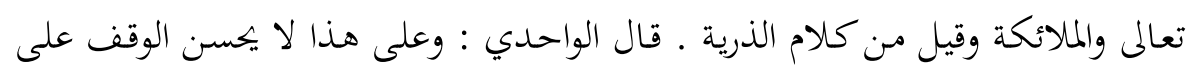

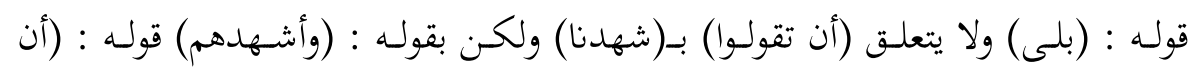

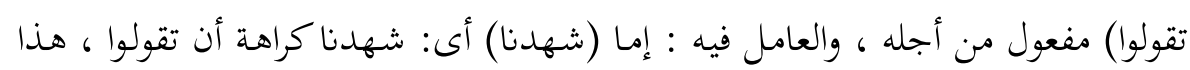

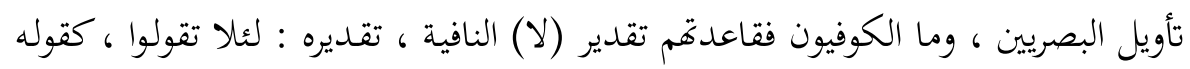
تعالى : (أن تميد بكم) النحل : 10.

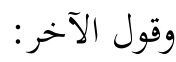




$$
\text { رأينا ما رأى البصراء فيها آلينا عليها أن تباعا }
$$

أى : ألا تباع ، وأما (وأشهدهم) أى : أشهدهم لعلا تقولوا ، أو كراهة أن تقولوا ـ وقد أند

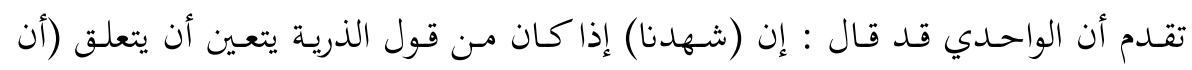

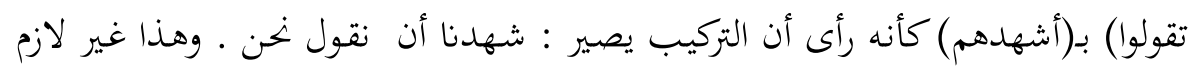

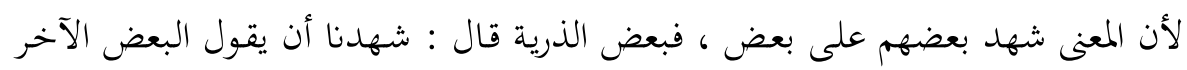

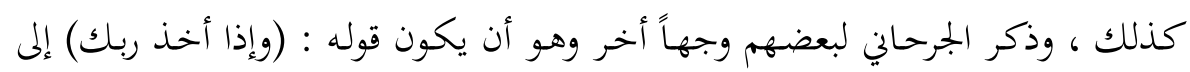

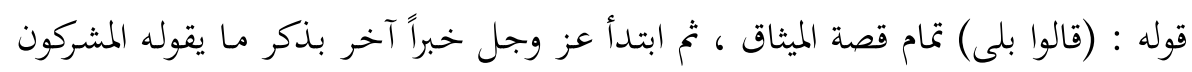

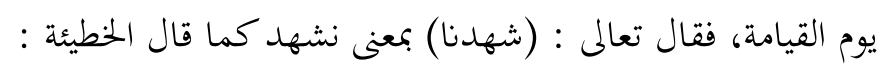

$$
\text { شهد الحطيئة حين يلقى ربه ........... }
$$

أى يشهد فيكون تأويله (يشهد أن تقولوا)

势 1ro

$$
\text { وقرأ أبـو عمـرو (يقولـوا) في الموضعين بالغيبـة جـريا على الأسمـاء المتقدمـة ، والبـاقون }
$$

بالخطاب، وهذا واضح على قولنا إن )شهدنا) مسند لضمير الله تعالى ـ وقيل على قراءة

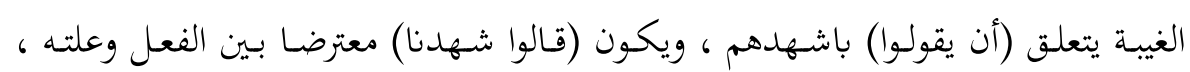

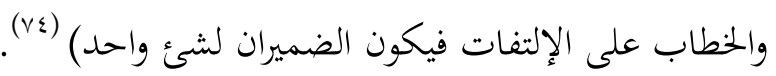

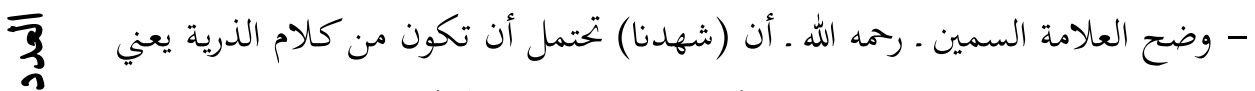

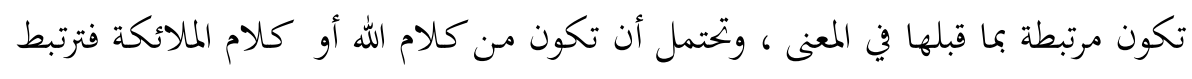

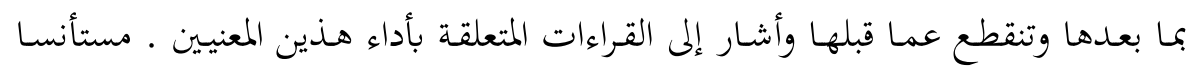
بكلام العلامة الواحدي ـ رحمة الله عليه . (vo).

\section{القرطبي والألوسي}

أما الأول فقد فصل القول في التجاذب في هذا الموضع ، مبينا ما يترتب على ذلك

$$
\text { من الوقف والابتداء ، وما جرى مع هذين المعنيين من القراءات . }
$$

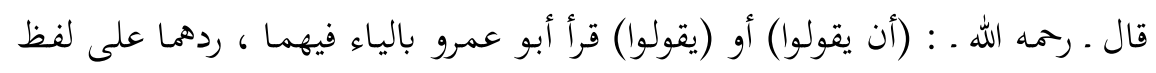

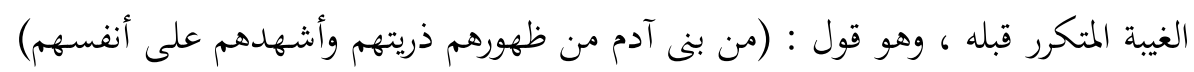

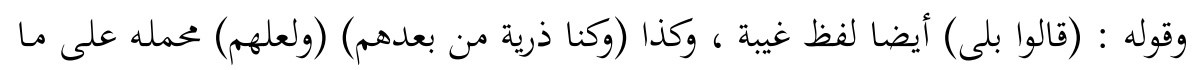

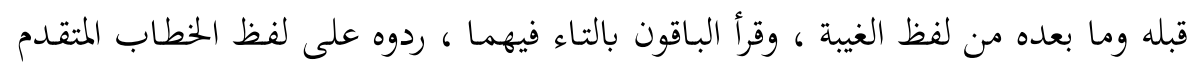


في قوله : (ألست بربكم قالوا بلى) ويكون (شهدنا) من قول الملائكة ، لما قالوا : (بلى)

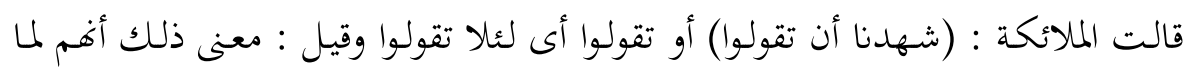

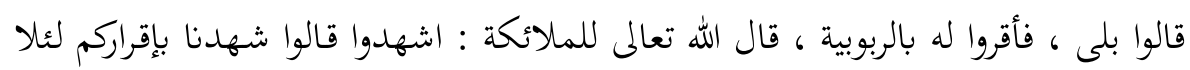

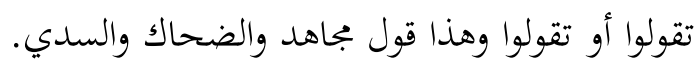

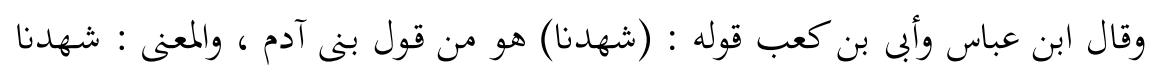

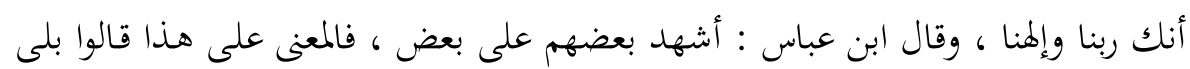

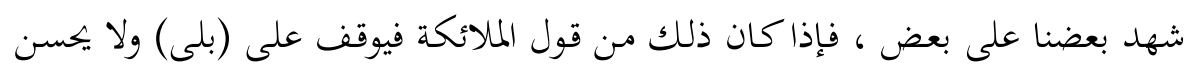

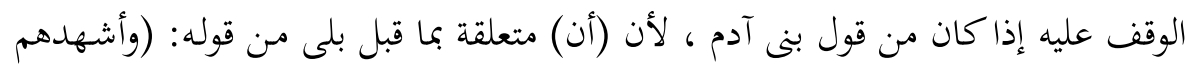

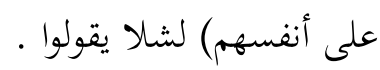

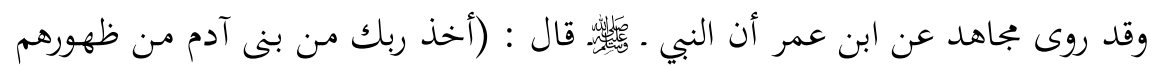

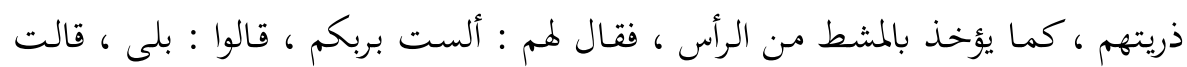

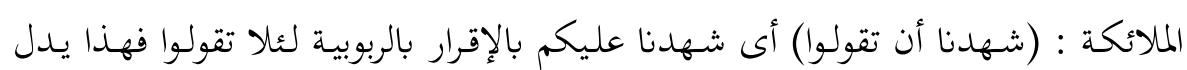

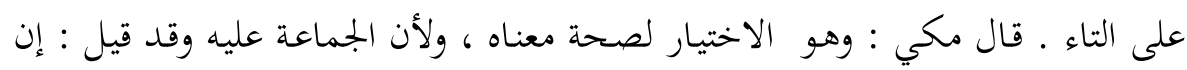

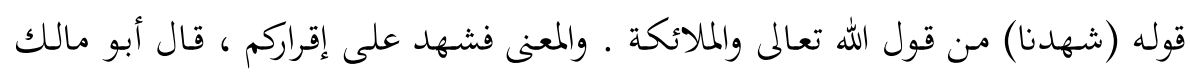

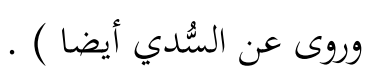

هقد رأينا العلامة القرطبي فصل القول في ارتباط (شهدنا) بما قبله حيث يكون منه قول

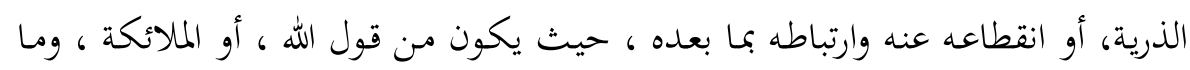

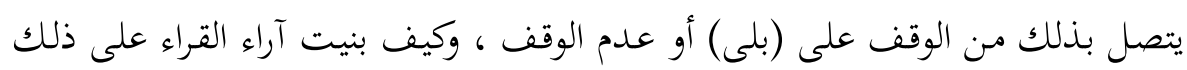

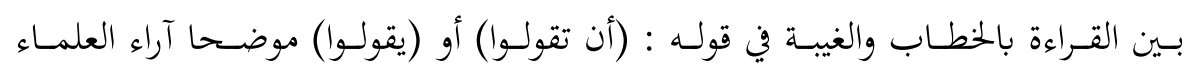
توضيحاً شافياً . وأما الثاني (العلامة الألوسي)- رحّه الله- فقد بنى قوله بالتجاذب على التوجيه الإعرابي

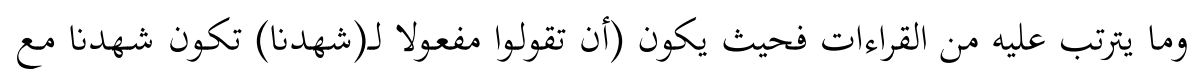

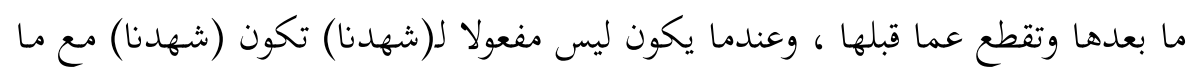

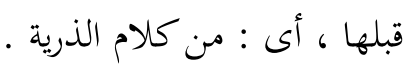
قال ـ رحمه الله ـ : (وجعلوا قوله ـ سبحانه وتعالى . : (أن تقولوا) من تلوين الخطاب

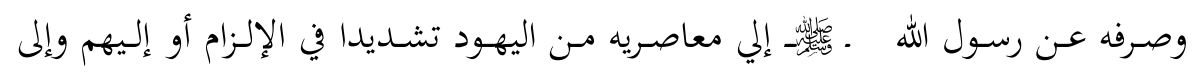


متقدميهم بطريق التغليب ، وهو مفعول له لما قبله من الأخذ والإشهاد ، أو لمقدر يدل

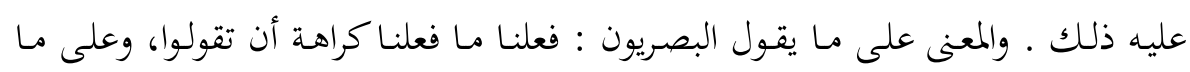

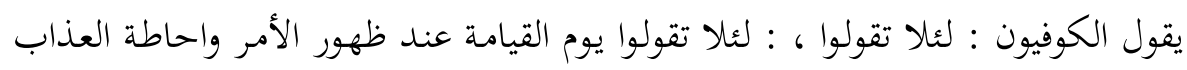

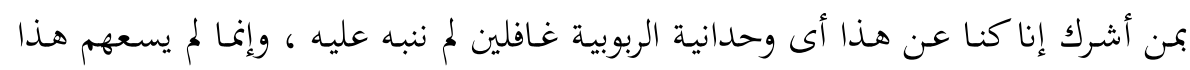

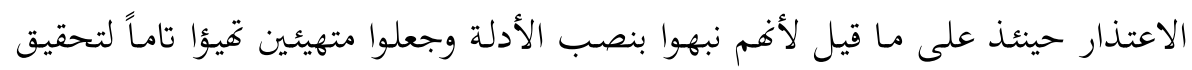
الحق وإنكار ذلك مكابرة فكيف يمكنهم أن يقولوا ذلك) (Vح).

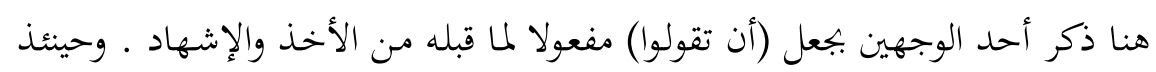

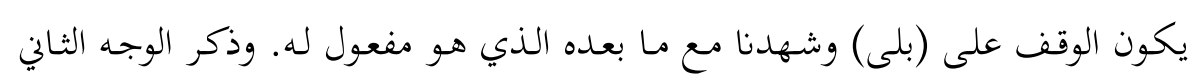

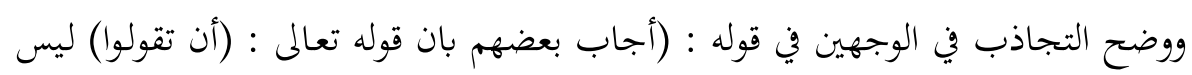

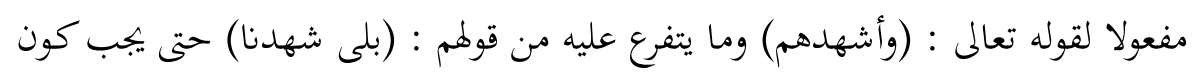

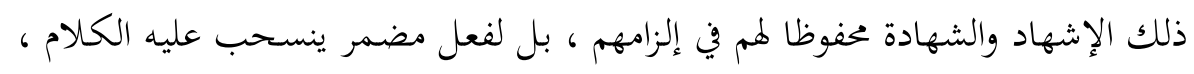

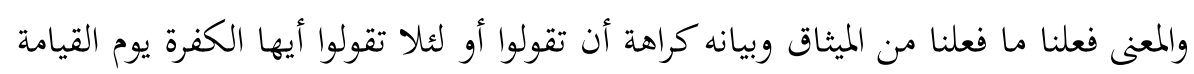

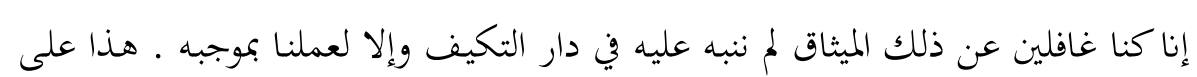
قراءة الجمهور ، أما على القراءة الأخرى فهو مفعول له لنفس الأمر المضمر العامل في (إذا لمافيه

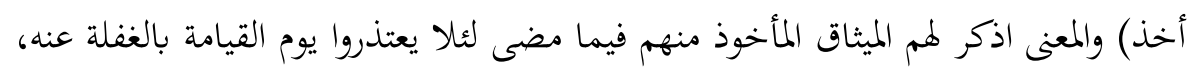

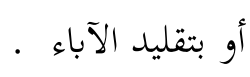
ثم قال : هذا على تقدير كون (شهدنا) من كلام الذرية وهو الظاهر ، فأما على تقدير

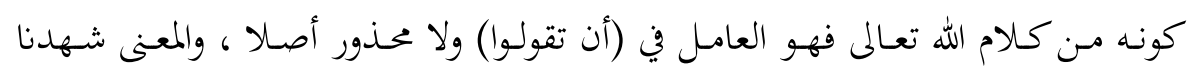

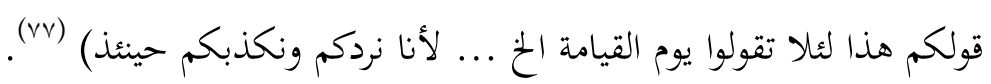
الثهاب وأبو السعود والجزي ثلاثتهم - بينوا التجاذب في هذا الموضع وبهم ننهي الحميث فيه مكتفين بما عرضناه من

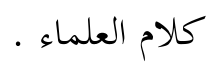

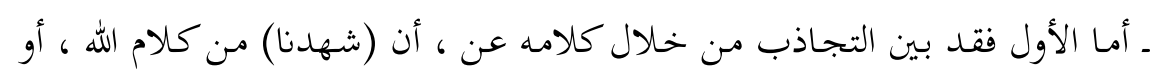
من كلام الذرية مؤسسا كلامه على التوجيه الإعرابي من جهة ، والقراءات الواردة في الآية من جهةأخرى، قال ـ رحمه الله . : 


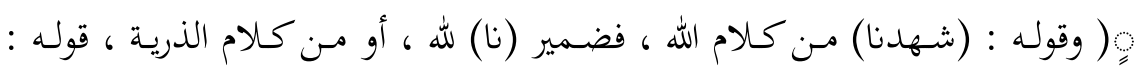

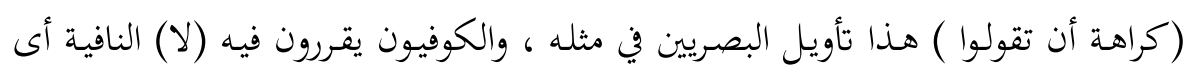

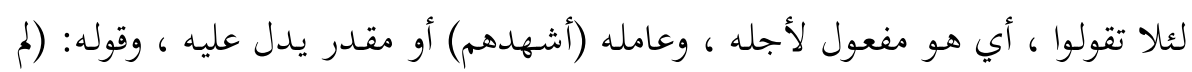
ننبه) بصيغة المجهول تفسير للغفلة .

وقراءة أبى عمر بالغيبة لقوله : (أشهدهم) وقراءة الخطاب لهم ، لقوله : (ربكم) (V^).

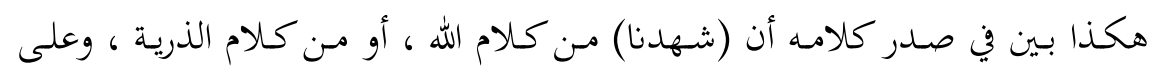

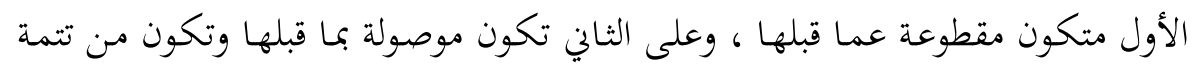

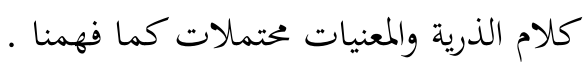

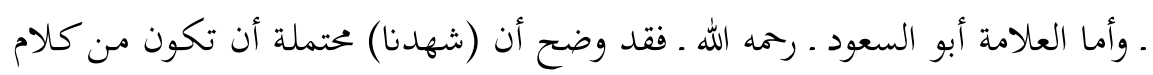

الذرية فتكون الذرية هي التي قالت: (بلى شهدنا) وتكون شهدنا مع ما قبلها.

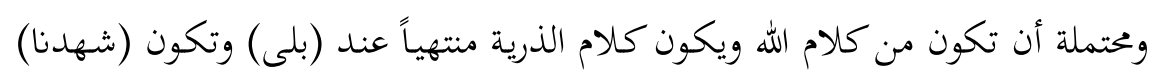

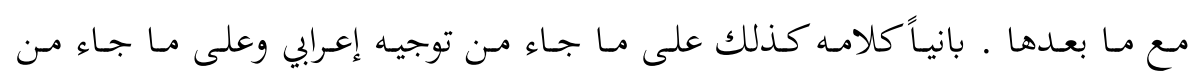
قراءات، وعليهما بتأسس معنى المصطلح البلاغي (التجاذب) في هذا الموضع .

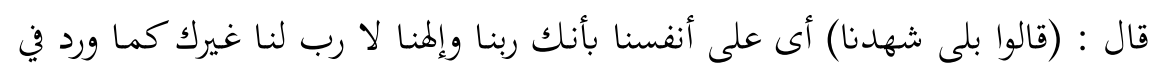

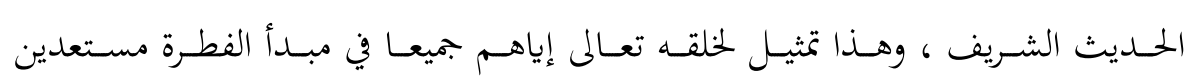
للاستدلال بالدلائل المنصوبة في الآفاق والأنفس المؤدية إلى التوحيد والإسلام .... وقوله:

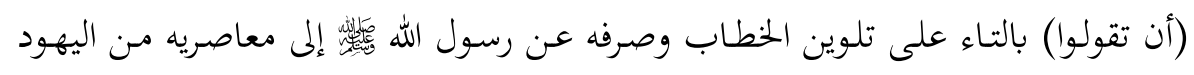

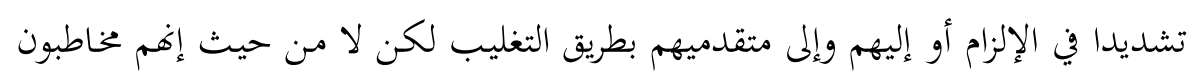

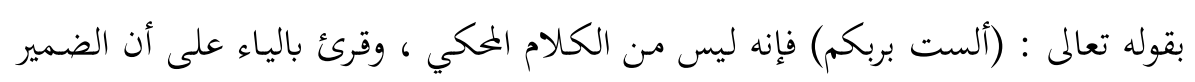

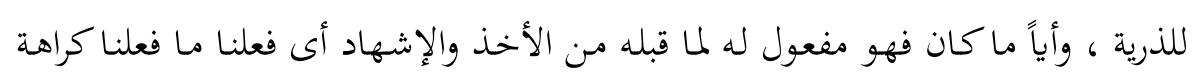
أن تقولوا أو لئلا تقولوا أيها الكفرة أو يقولوا هم (يوم القيامة) أو عند ظهور الأمر (إنا كنا

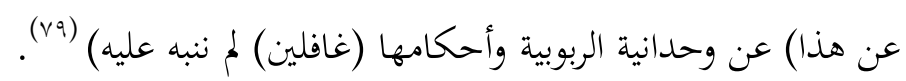

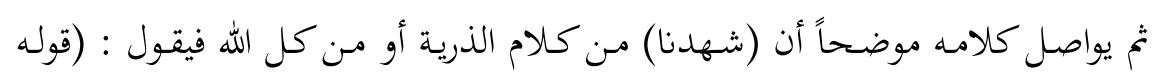

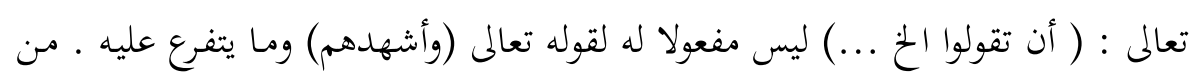

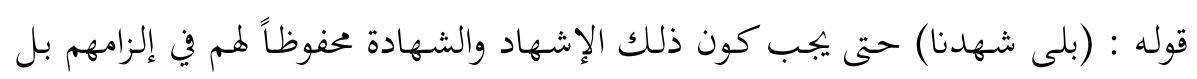


لفعل مضمر ينسحب عليه الكلام ، والمعنى فعلنا مـا فعلنا من الأمر بذكر الميثاق وبيانه كراهة أن تقولوا ، أو لئلا تقولوا أيها الكفرة يوم القيامة إنا كنا غافلين عن ذلك الك الميثاق لم الم

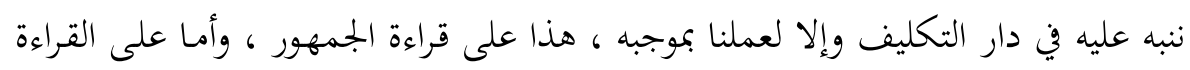

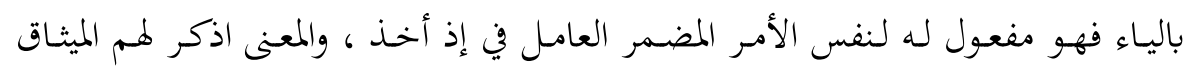

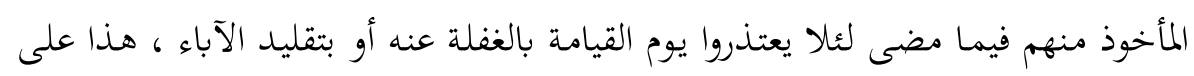

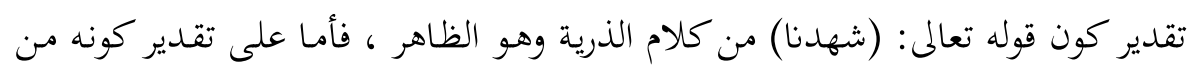

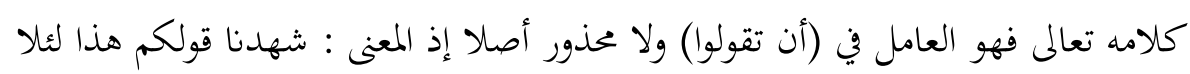

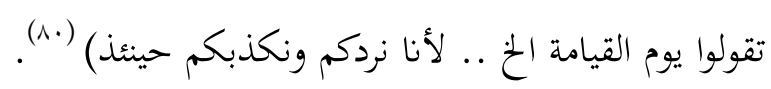

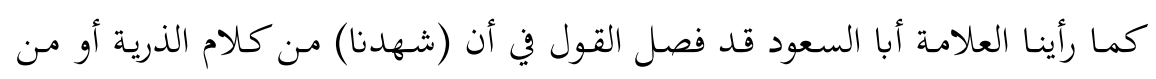

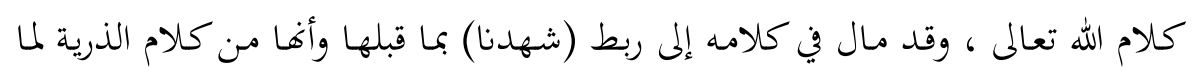

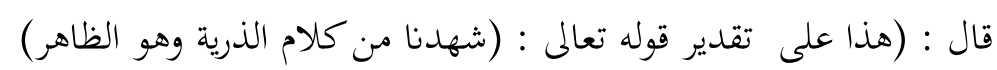

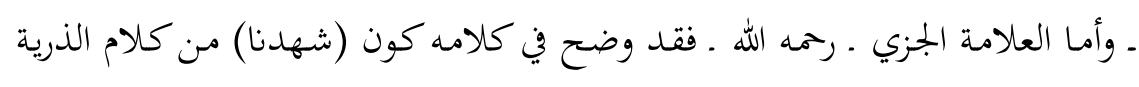

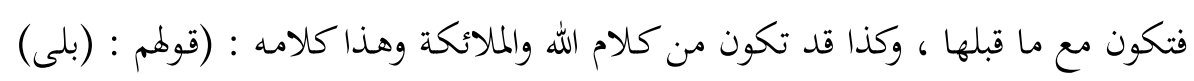
149

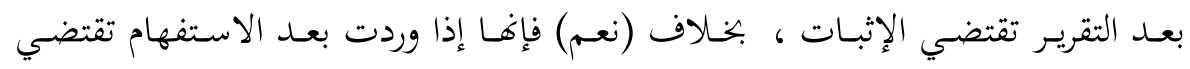

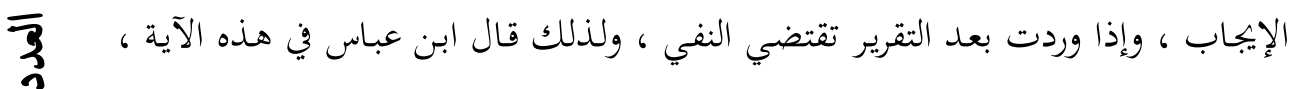

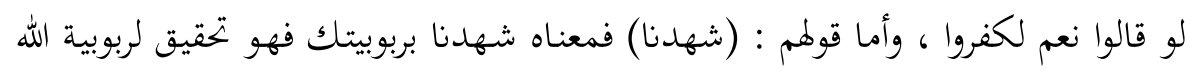

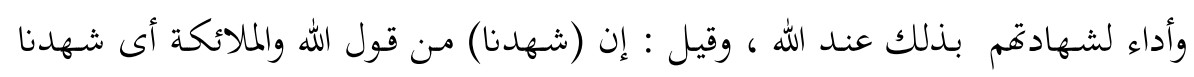

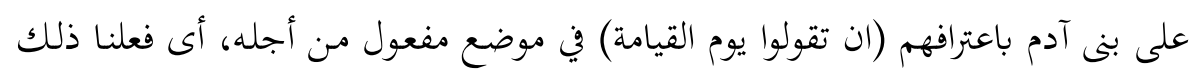

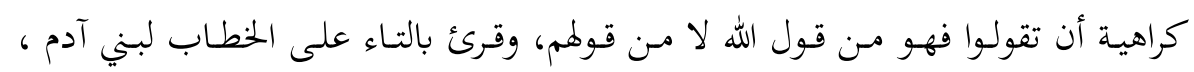
وبالياء على الإخبار عنهم) (1). 


\section{المبحث السادس : التجاذب في \\ (الذين آتيناهم الكتاب)}

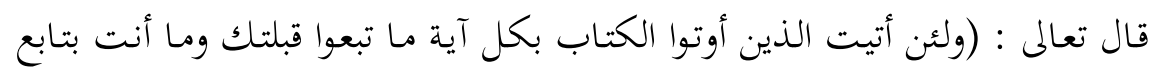

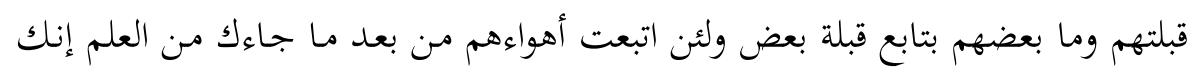

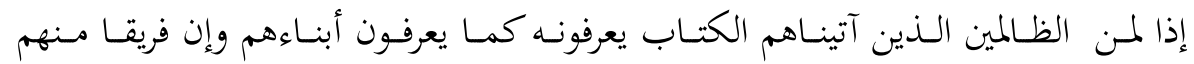

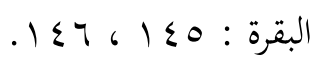

$$
\begin{aligned}
& \text { ليكتمون الحق وهم يعلمون). (AT) }
\end{aligned}
$$

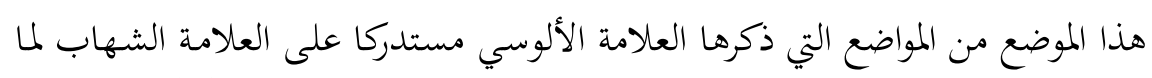

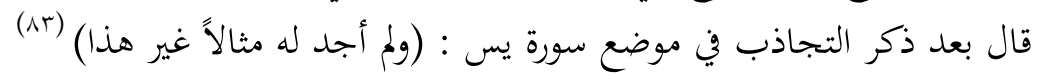

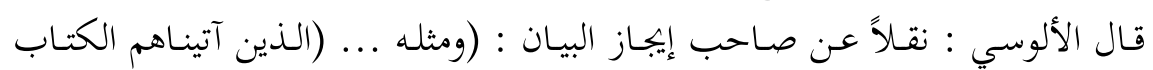

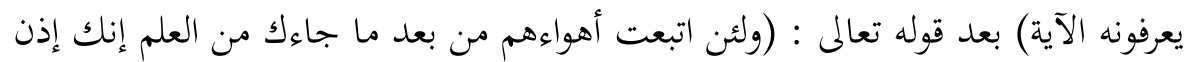

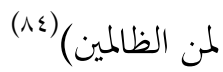

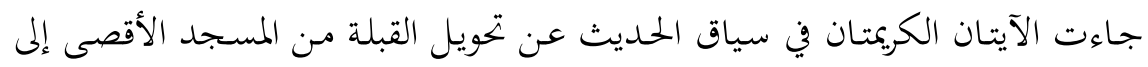

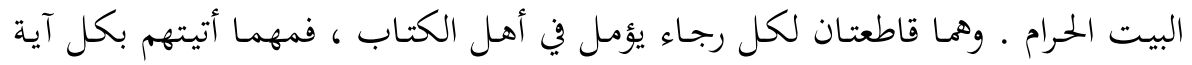

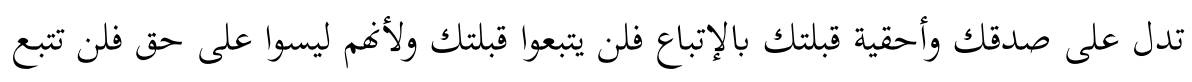

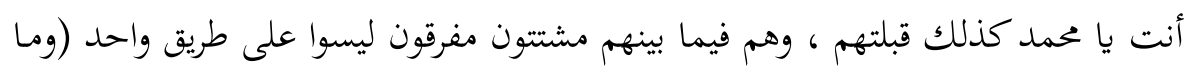

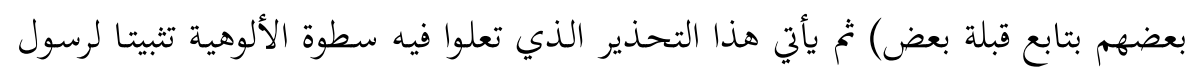

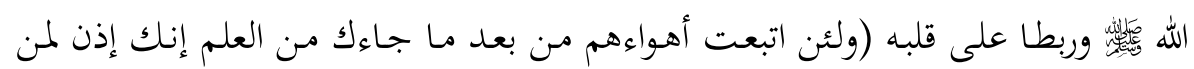

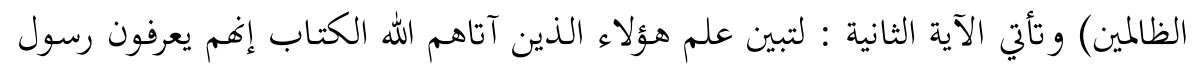

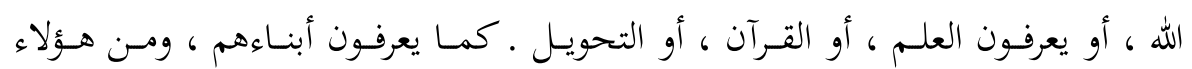

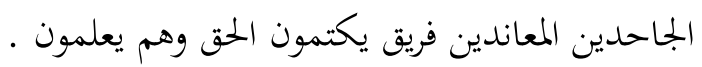

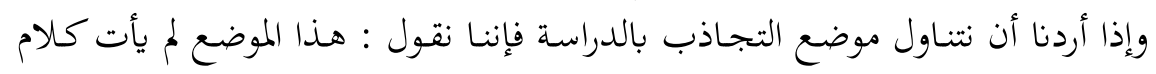

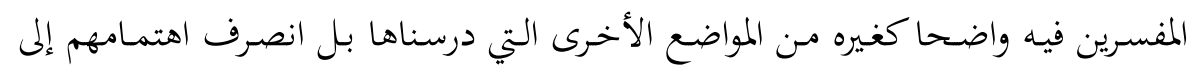

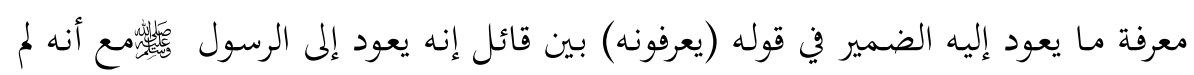
يسبق ذكره في الكمام ولكن السياق يدل عليه ، في قوله بعلده (كما يعرفون أبناءهم) وبين قائل : إنه مذكور قبله وقد جرى الكلام على توجيه الخطاب له في الآيات السابقة

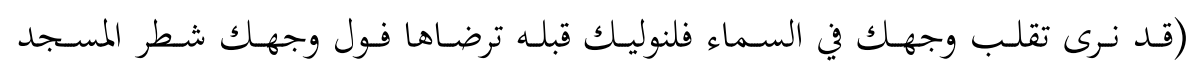

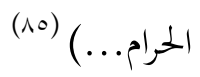


وبين قائل : إن الضمير عائد إلى العلم ، أى يعرفون العلم ، أو إلى القرآن ، وبين قائل:

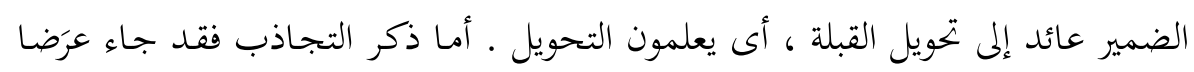

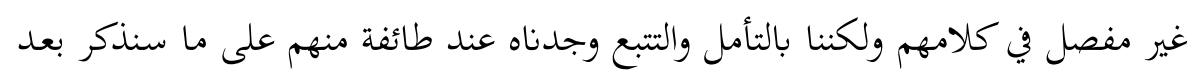
قليل .

$$
\text { وموضع التجاذب هنا في قوله تعالى : (الذين آتيناهم الكتاب) . }
$$

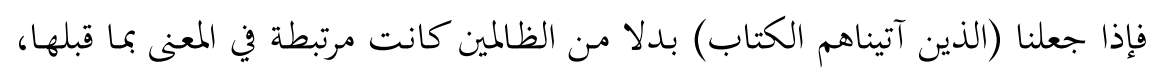

$$
\text { فالذين آتيناهم الكتاب هم الظالمون . }
$$

وقد نقطع (الذين آتيناهم...) عما قبلها ، ونبدأ بها على أغها كلام مستأنف (الذين)

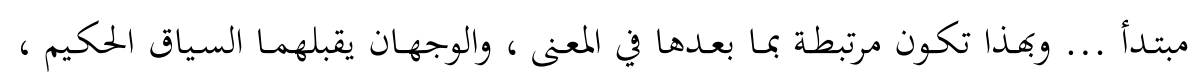
وهذا هوالتجاذب.

والآن نحاول استبيان ذلك في كلام العلماء الذين جاء في كلامهم ذلك غير مفصل كما

$$
\text { في المواضع الأخرى . }
$$

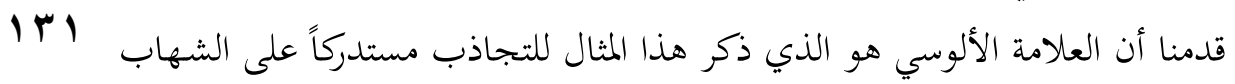

الخفاجي في حديثهما عن التجاذب في موضع سورة يس ( من بعثنا من مرقدنا هذا)

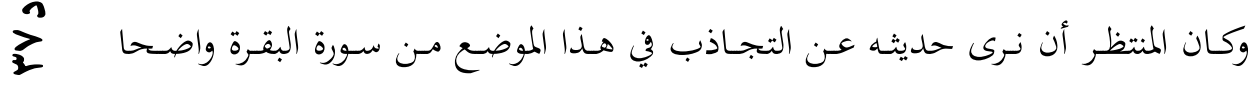

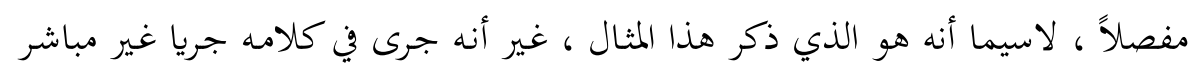
وغير مفصل حيث ذكر في (الذين) وجهين :

الاستئناف ، او أها بدل من (الظالمين) أو من الموصول الأول ، وسنبدأ كلامه من أول

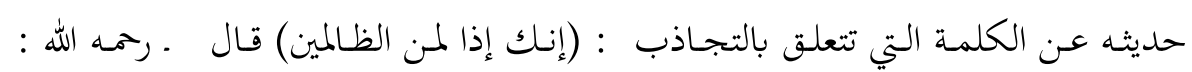

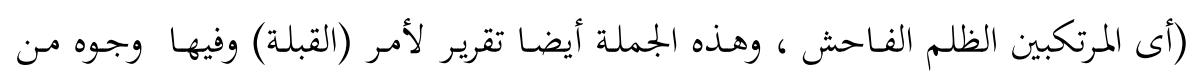

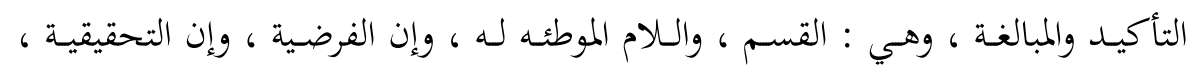

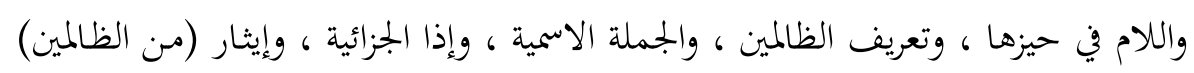

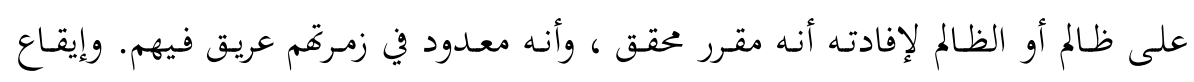

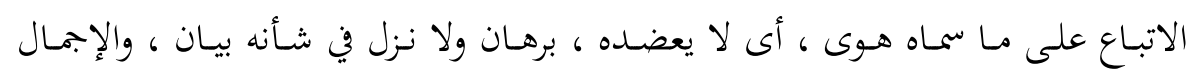


والتفصيل ، وجعل الجائي نفس العلم ، وعد أيضا مـن ذلك عده واحدا (من الظالمين)

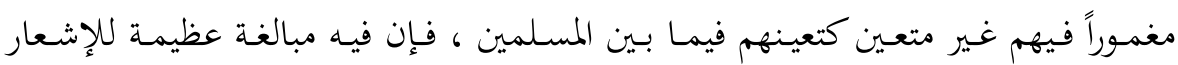

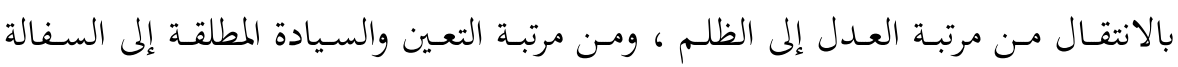

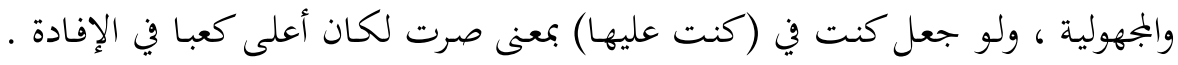

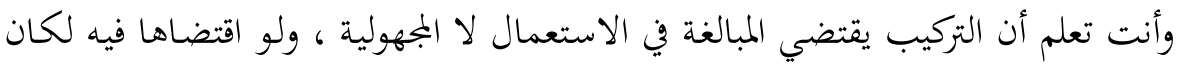

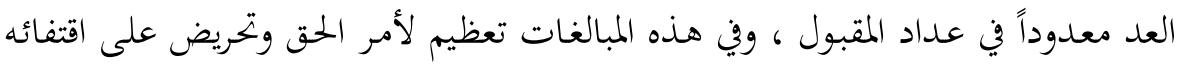

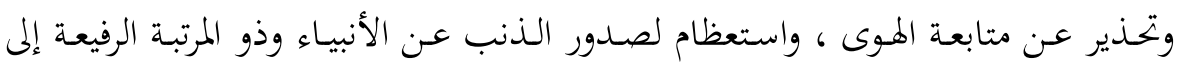

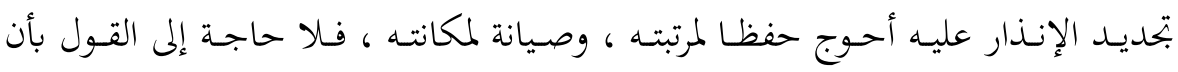

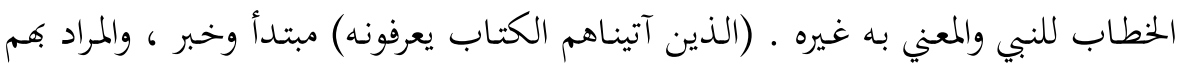

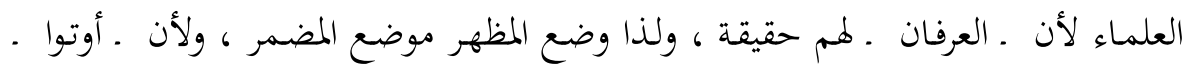

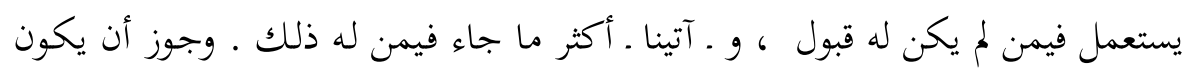

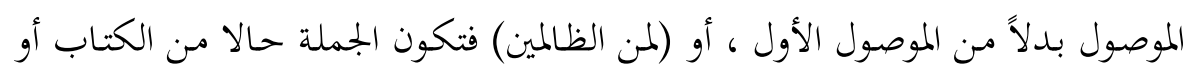

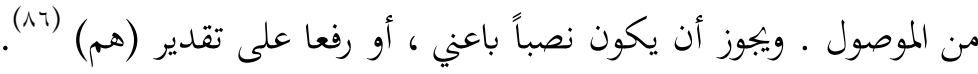

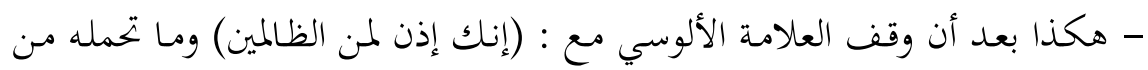

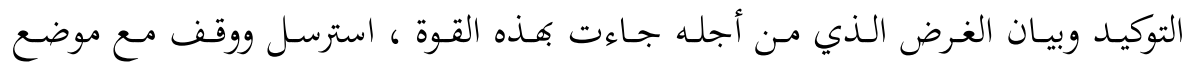
التجاذب دون أن يصرح به ، فجعل (الذين آتيناهم الكتاب يعرفون ) مبدءا وخبرا .

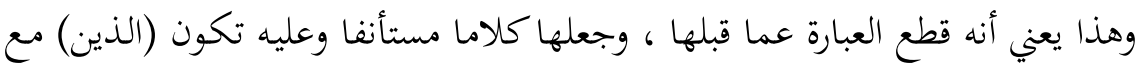
ما بعدها ولا تعلق لما بما قبلها (الظالمين) وعلى هذا يكون المراد بـ(الذين) العلماء ، وعلل لذلك ، يوضع المظهر (الذين) موضع الضمير ، ولم يقل ، هم آتيناهم ليظهر أن (الذين)

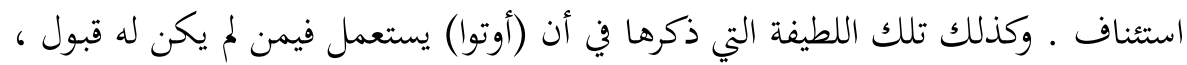

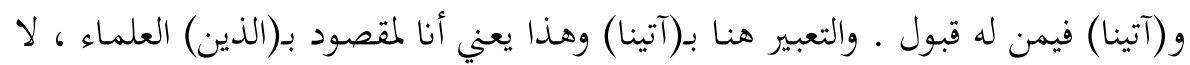
الظالمين . ثم عـاد وذكر الوجه الثاني للتجاذب ، حيث جعل (الذين) بدلا من الموصول الأول ، وهو (الذين) في قوله : (ولئن أتيت الذين أوتوا الكتاب بكل آية) أو بدلا من (الظالمين)

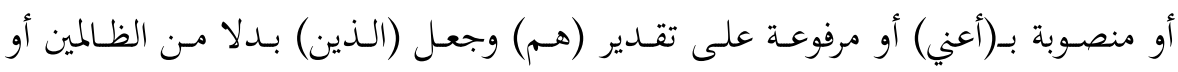

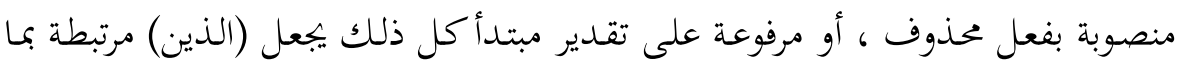


قبلها ، ويكون المعنى أن الذين أوتوا الكتاب هم عين الظالمين . وعلى التقديرين يتضح التجاذب في (الذين ...) فقد يقصد بهم الظالمون ، أو العلماء على التوجهين . (القئ

\section{العلامة السمين}

ومن العلماء إلذين أشاروا إلى التجاذب في هذا الموضع العلامة السمين ـ رحمه الله ـ فقد

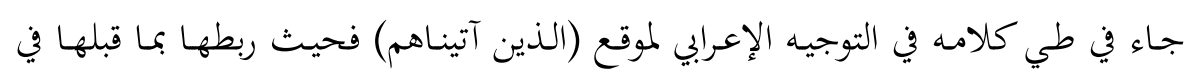

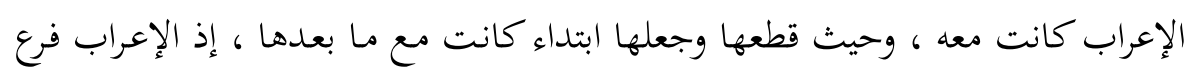

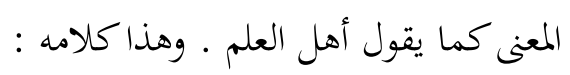

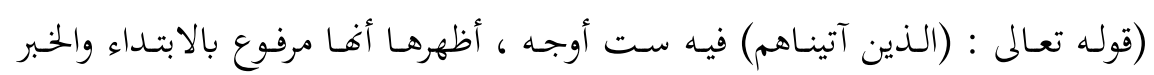

$$
\text { قوله(يعرفونه) }
$$

$$
\text { والثاني : أنه خبر مبتدأ محذوف ، أى : هم الذين آتيناهم . }
$$

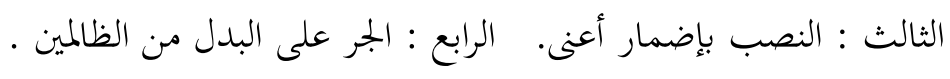

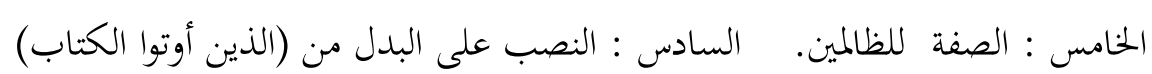

واضح في كـلام العلامـة السـمين أن (الـذين) تعـرب مبتـدأ ، وخـبراً لمبتـدأ محذوف ،

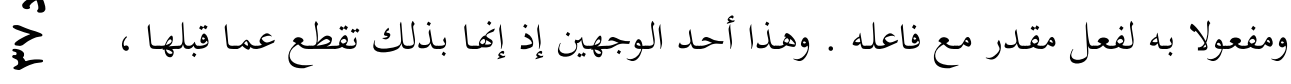

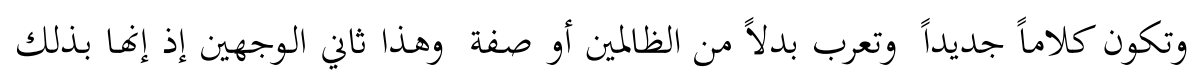

تربط في المعنى بما قبلها

\section{أبوحيان}

ذكر العلامة أبو حيان ـ رحمة الله عليه ـ وجهي الإعراب الدالين على اختلاف المعنى

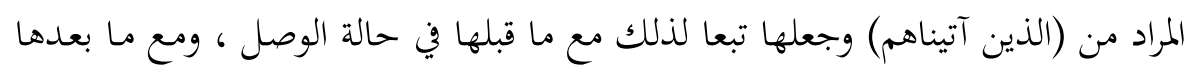

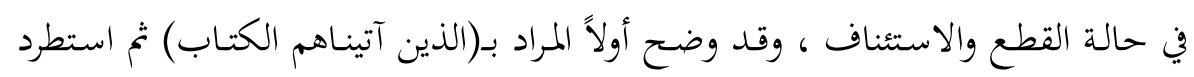
فذكر التجاذب على النحو الذي أشرنا إليه .

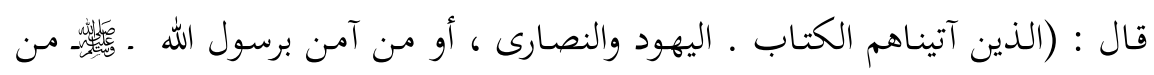

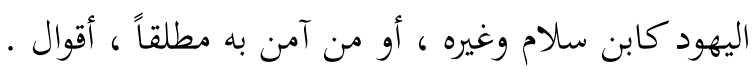


والكتاب : التوراة أو الإنجيل ، أو مجموعهما ، أو القرآن ـ أقوال تنبني على مَن المراد

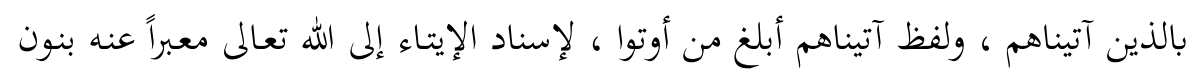

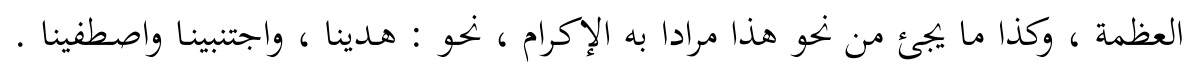

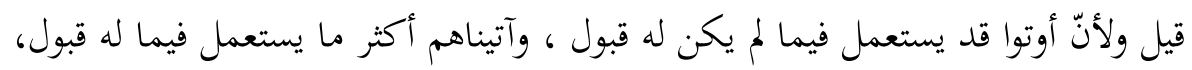

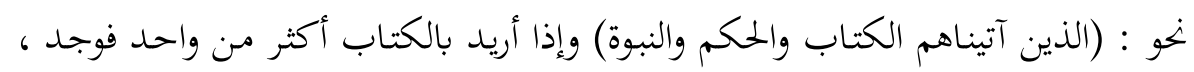

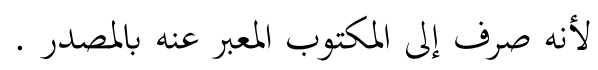

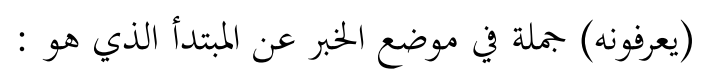

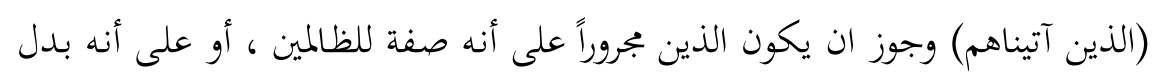

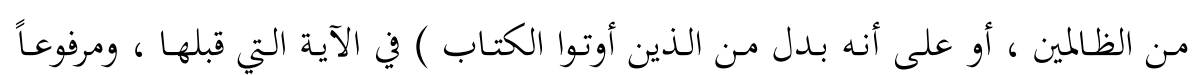

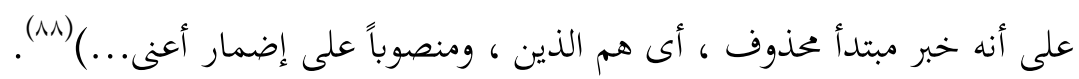

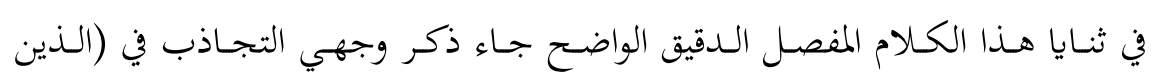
آتيناهم) ترتيبا على تغاير الإعراب ، حيث ذكر ـ رحمه الله ـ أن (الذين آتيناهم) مبتدأ خبره

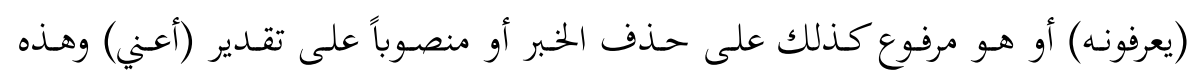

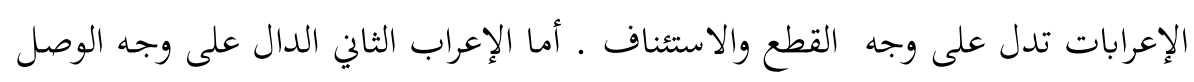
والربط بما قبلها فهو جعل الذين آتيناهم بدلا من الظالمين أو صفة من الظالمين ، والئن ، والمعنيان متغايران والسياق يقبلهما معاً.

\section{ابن عطية والقرطبي}

ومسن العلماء الذين وجهوا الإعراب في (الذين) توجهين ينبني عليهما وجها التجاذب

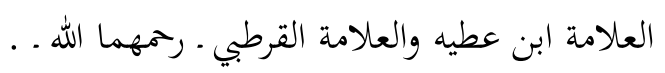

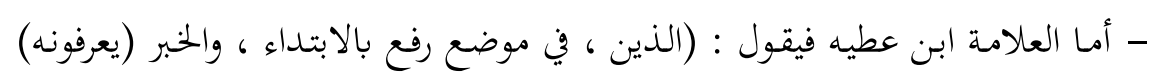

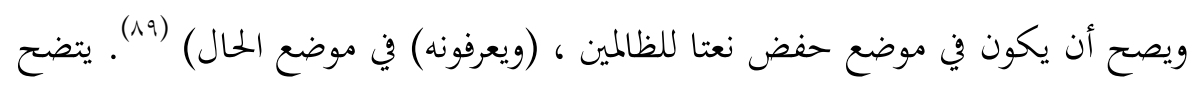

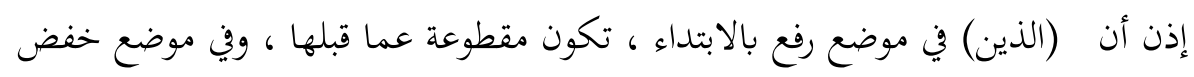
نعتا للظالمين تكون مع ما قبلها .

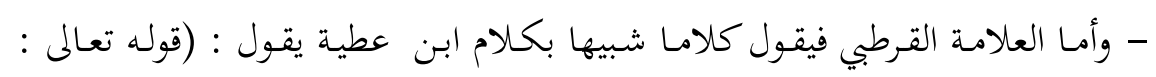

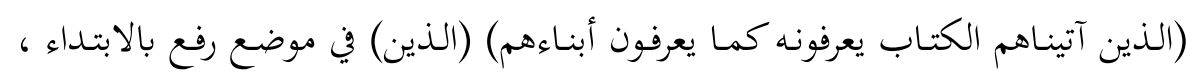


والخبر (يعرفونه) ويصح أن يكون في موضع حفض على الصفة ل(الظالمين) ، و (يعرفون) في

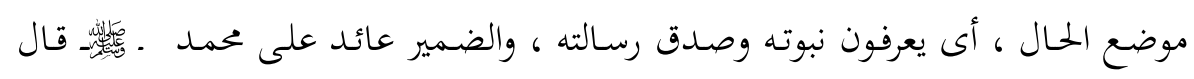

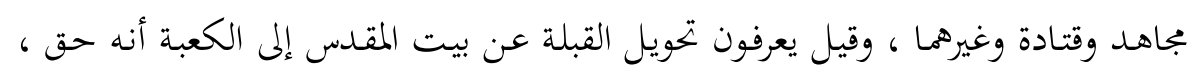
قاله ابن عباس وابن جريج والربيع وقتادة أيضا) (.9.).

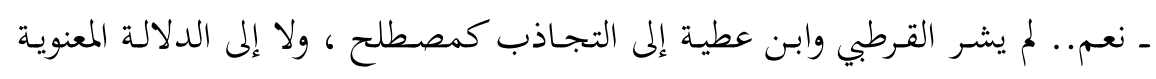

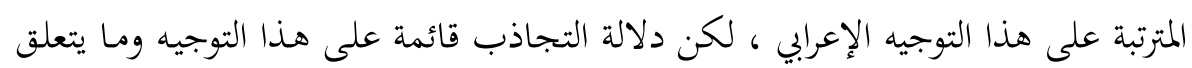

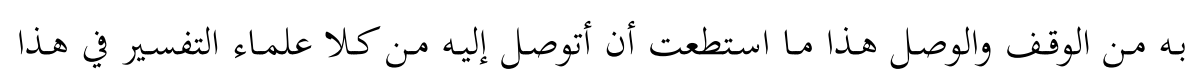

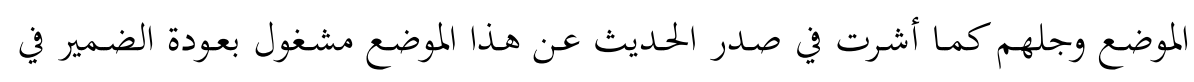
(يعرفونه)

\section{العلامة الزَّبَّاج}

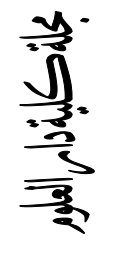

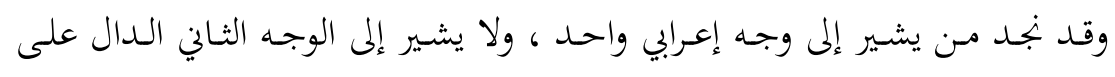

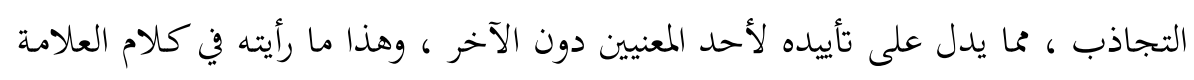
الزجاج • رحمه الله ـ وهو كذلك مشغول بعودة الضمير في (يعرفونه)

Iro

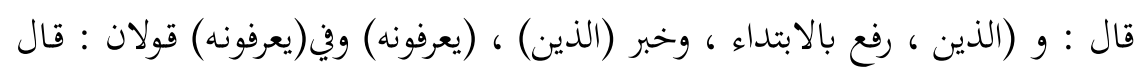

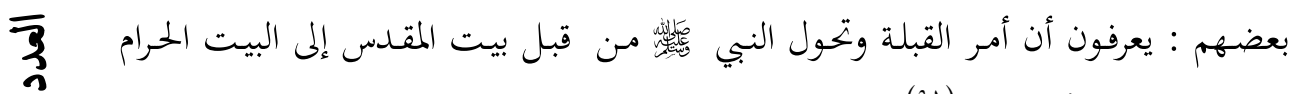

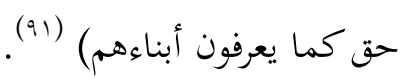
- وبهذا القدر اكتفى إذ الدراسة لا تتسع لأكثر من ذلك ، وهناك مواضع تحتاج إلى

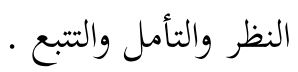

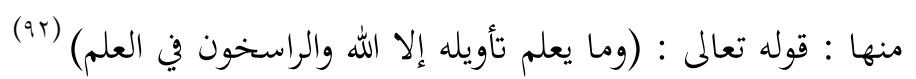

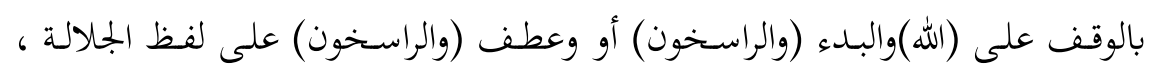
على اختلاف القراءات في ذلك . لمأك

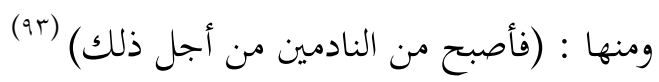

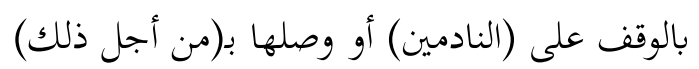

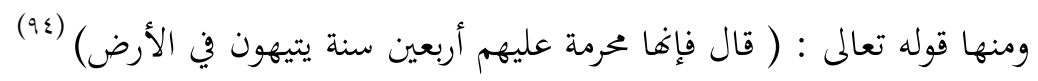

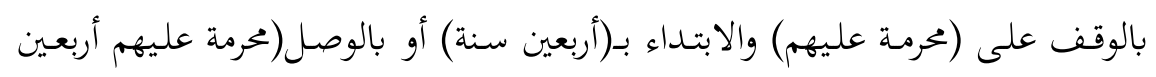


سنة) ومنها :( (كذلك يبين الله لكم الآيات لعلكم تتفكرون في الدنيا والآخرة)(90)

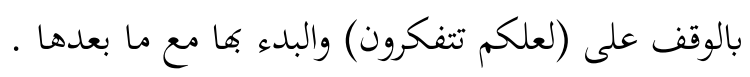

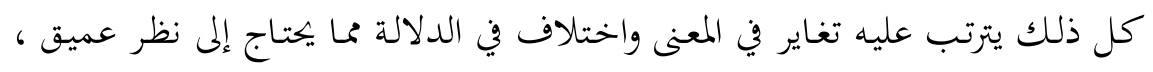

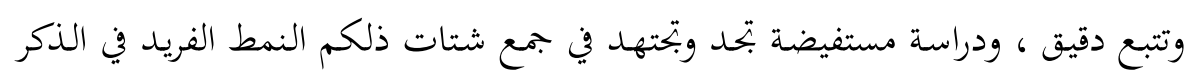
الحكيم ، وحسبنا أننا دللنا على الطريق .

\section{الملنـاتمــاتة}

الحمد لله القائل : (وتلك الأمثال نضربها للناس وما يعقلها إلا العالِمون) (ج9) وأصلى

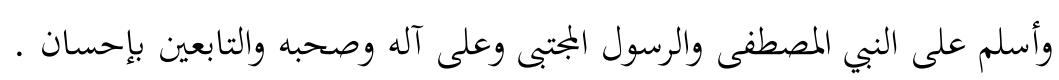
وبعد ...

فإها لعشرة حميدة عايشتها مع كتاب الله العزيز حتى قلت : إن كان للأرواح متاع في

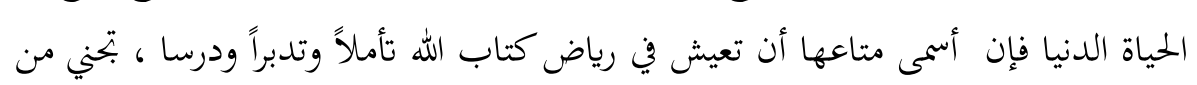

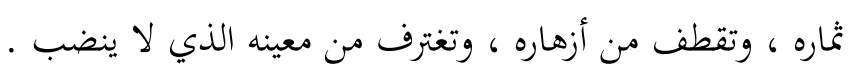

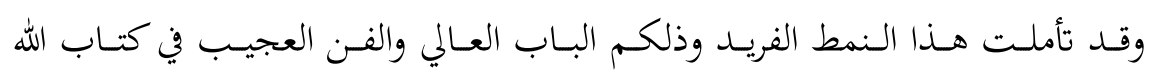

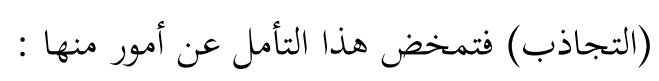
- أنني لمج أعرف واحدا من البلاغيين ولا من المفسرين ذكر هذا المصطلح (التجاذب)

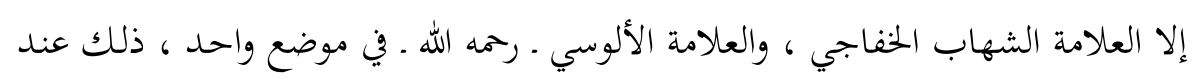

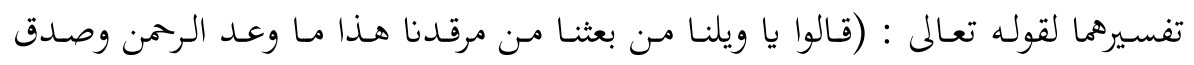

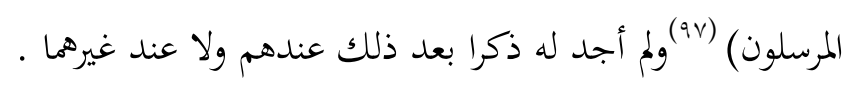

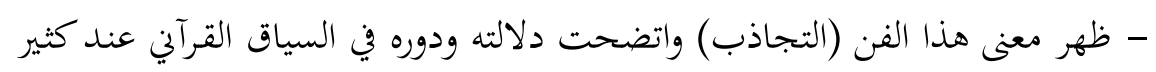
من المفسرين دون أن يجري هذا المصطلح على ألسنتهم ، ولعل مردّ ذلك إلى أفم لم يعرفوا

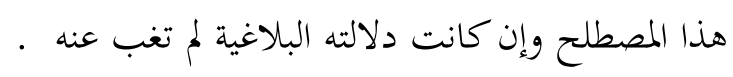

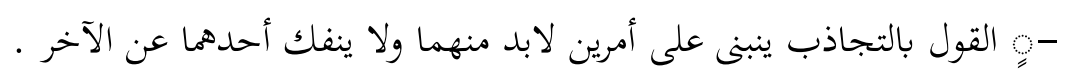

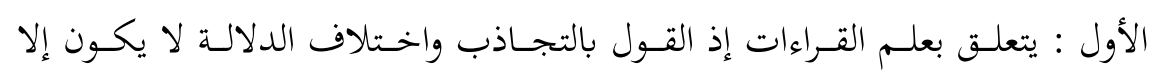

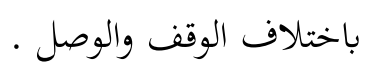
الثاني : يتعلق بعلم النحو إذ القول به لا ينفك عن التوجيه الإعرابي حيث تأتي الدلالة 


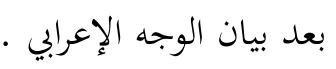

ثم يتمخض عن هذين الأمرين البحث في سر اختلاف الدلالة ، ودور السياق في بيان

$$
\text { اختلاف المعنى باختلاف الوصل والوقف ، وتغايره بتغاير الوجه الإعرابي . }
$$

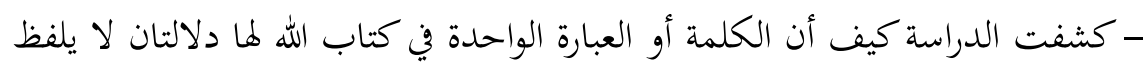

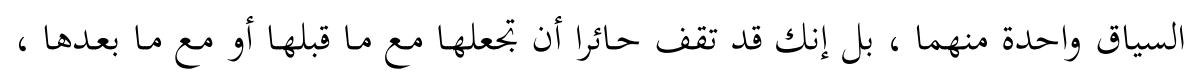
ولا تملك أمام هذا البيان القاهر لكل بيان إلا أن بتعلها معهما على قدر واحد. بلد. ـ آمل أن تمدى هذه لدراسة الضئيلة إلى باب واسع من البحث في القرآن لكريم ، وربما

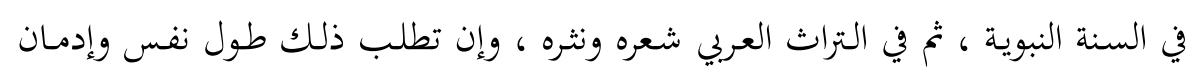
نظر ولا يطوع شئ من ذلك إلا لمن صبر وصابر.

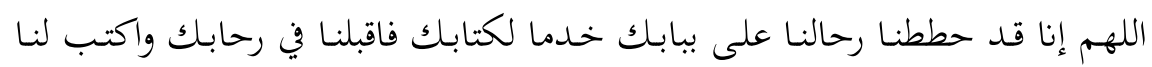
القبول عند أهل الفضل من علمائنا الأكارم ، واجعل مـا تخطه أيدينا شاهداً لنا لا علينا يوم نأتيك فرادي ـ وصلى الله وسلم على نبينا محمد وآله .

\section{فهرس المصادر والمراجع ونينا وحمد واله}

ITV

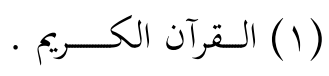

$\overline{3}$

(r)الإتقان في علوم القرآن للسيوطي ، مراجعة سعيد المندور ، الطبعة الأولى: ب ا1ـ اهـ . 1997

(r) إيهاز البيان عن معاني القرآن للنيسابوري ، تحقيق جنيف بن حصن القاسمي دار الغرب

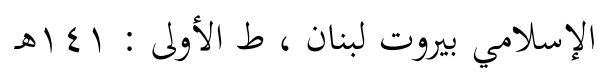

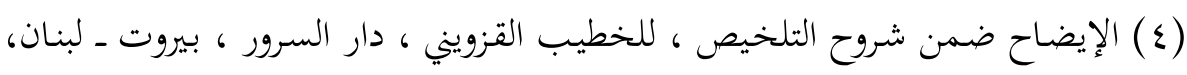
بدون تاريخ

(0) تاريخخ علوم البلاغـة والتعريف برجاهـا ، مصطفى المراغي ، مطبعة مصطفى البابي

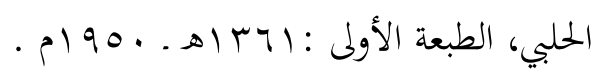

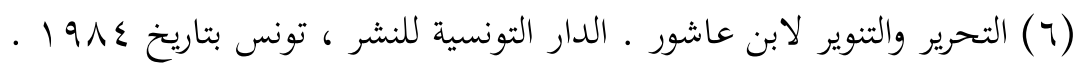

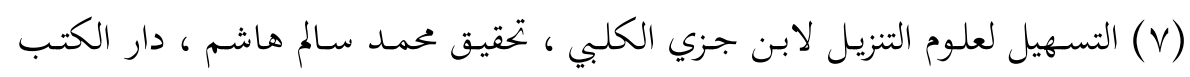

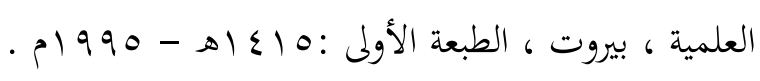


(^) تفسير أبى السعود (إرشاد العقل السليم إلى مزايا الكتاب الكريم ، دار إحياء التراث

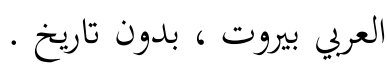

(9) تفسير البيضـاوي ضمن حاشية الشهاب : دار الكتب العلمية ، بيروت ، الطبعة

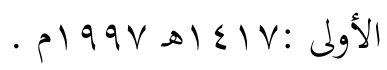

(· (1) التفسير الكبير أو مفاتيح الغيب للرازي. دار إحياء التراث العربي ، بيروت ، الطبعة الثالثة ، . أب أهـ (11) التفسير الوسيط للواحدي ، تحقيق وتعليق الشيخ عادل أحمد عبد الموجود ، الشيخ

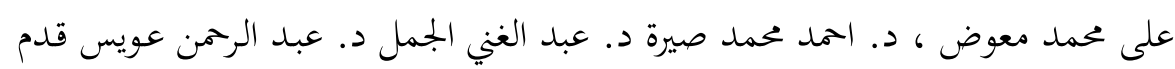

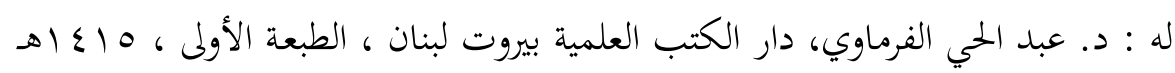
. $199 \varepsilon$. ( r ( ) الجامع لأحكام القرآن الكريم ، تحقيق أحمد البردوني ، وابراهيم أطفيش دار الكتب

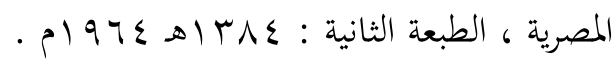

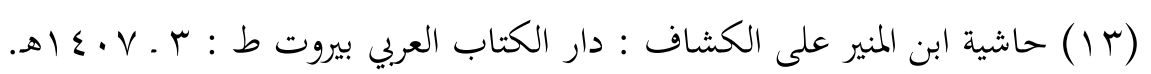

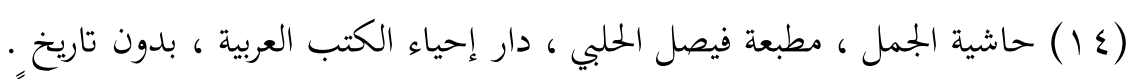

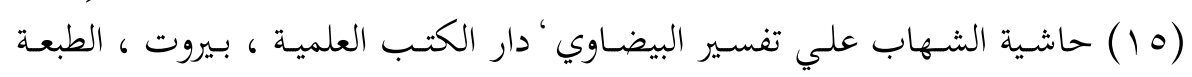

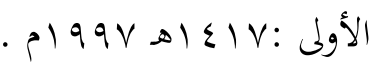

(7 1 ) الـدر المصون في علوم الكتـاب المكنون للسـمين ، أبو العبـاس شهاب الدين بـن

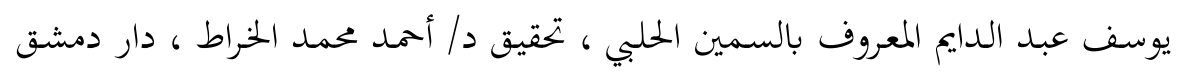

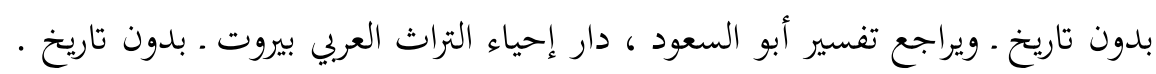

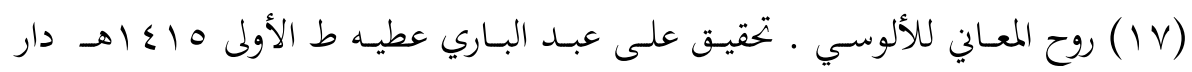

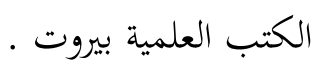
(1 (1) غرائب القرآن ورغائب الفرقان ، تحقيق الشيخ زكريا عميران ، دار الكتب العلمية

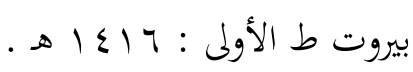

(9 1) فتح القدير الشوكاني دار ابن كثير ، دار الكلم الطيب ، دمشق بيروت . ط الأولى 


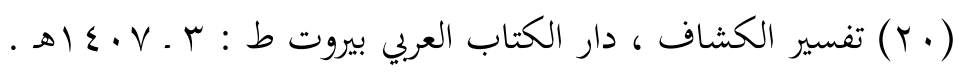

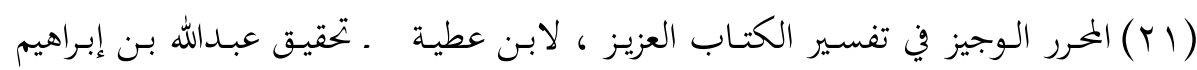

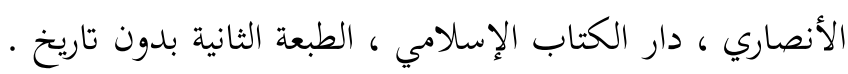

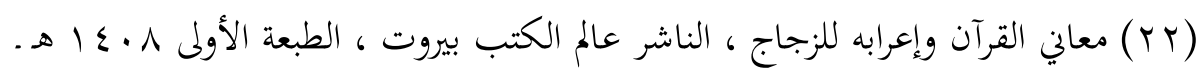

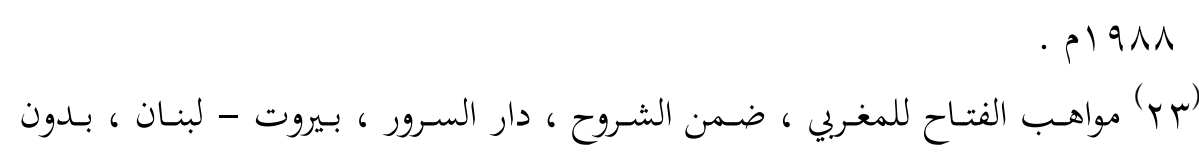
تاريخ. (؟ Y) النشر في القراءات العشر ، تحقيق محمد الضباع المطبعة التجارية الكبرى، تصدير دار الكتب العلمية ، بدون تاريخ.

(ro) نظم الدرر في تناسب الآيات والسور للبقاعي ، دار الكتاب الإسلامي ، القاهرة، بلدون تاريخ

\section{الهوامش والإحالات :}

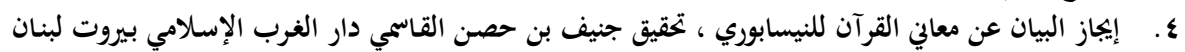

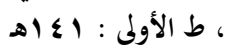

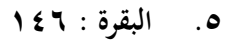

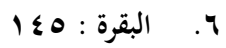

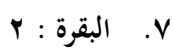
A.

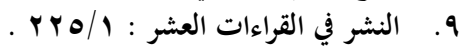
V :

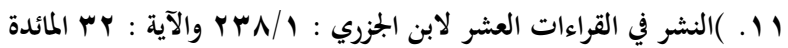

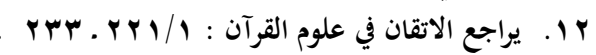

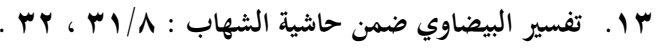

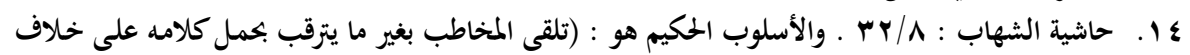

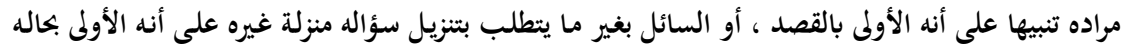

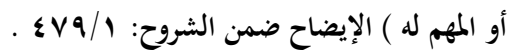

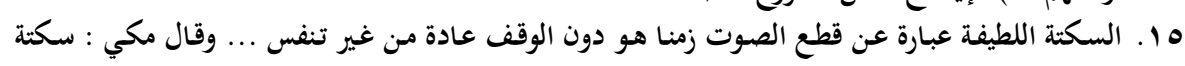

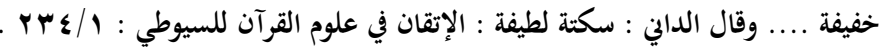




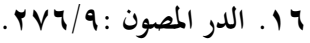

$$
\begin{aligned}
& \text { IV }
\end{aligned}
$$

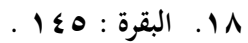

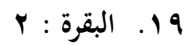

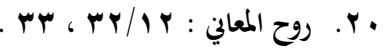

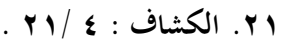

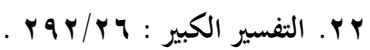

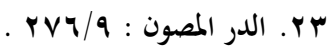

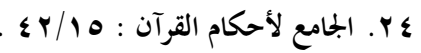

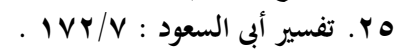

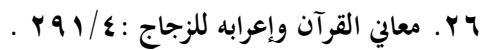

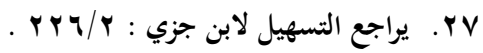

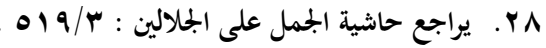

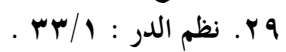

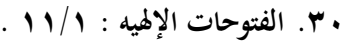

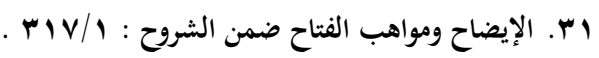

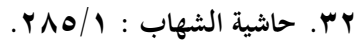

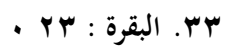

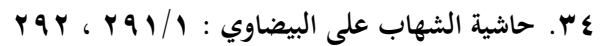

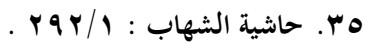

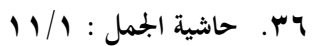

$$
\begin{aligned}
& \text { NV }
\end{aligned}
$$

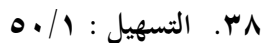

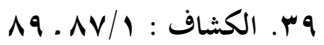

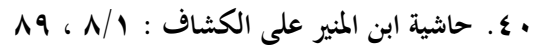

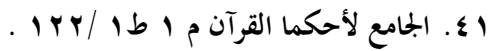

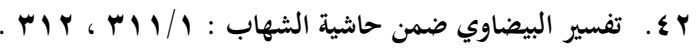

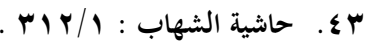

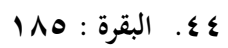

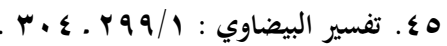

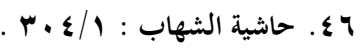

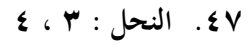

$$
\begin{aligned}
& \text { V ، } 7 \text { \& }
\end{aligned}
$$

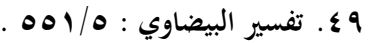

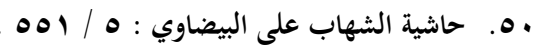

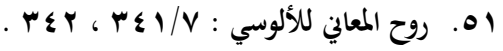

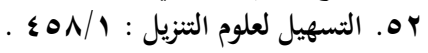




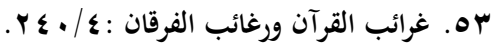

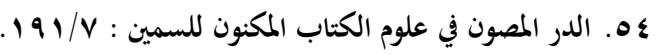

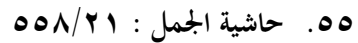 \\ צه

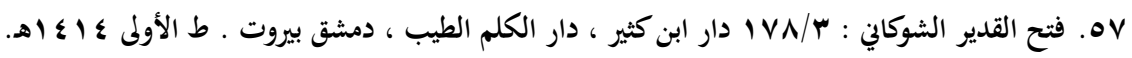

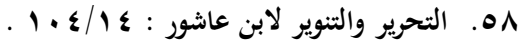

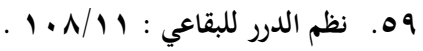 \\ • .

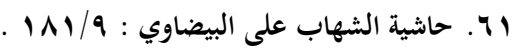

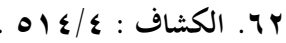

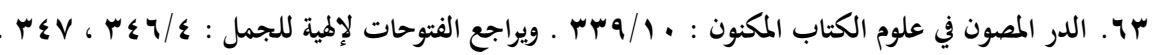

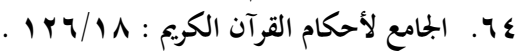

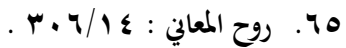

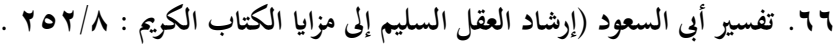

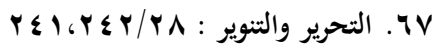

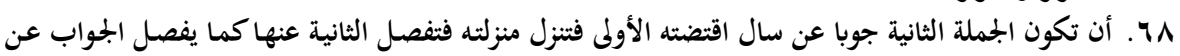

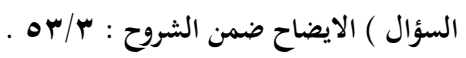

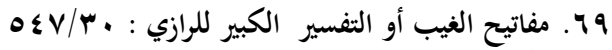 \\ ا V. الكشاف : ع /. عـ}

$1 \leq 1$

VY

ב

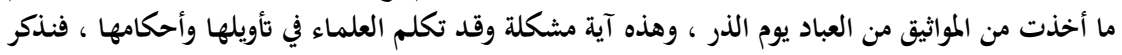

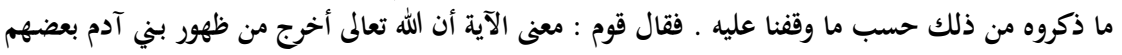

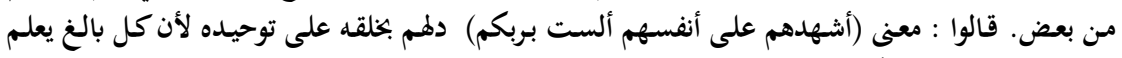

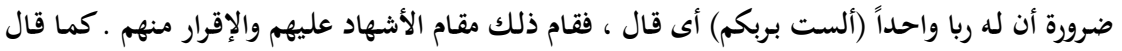

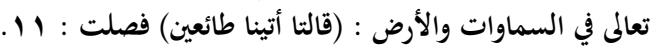

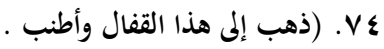

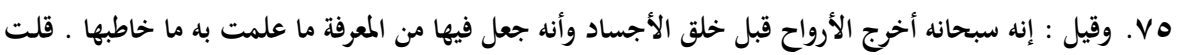

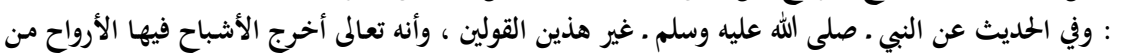

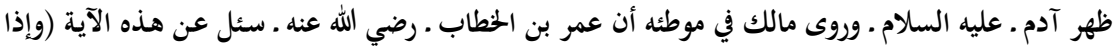

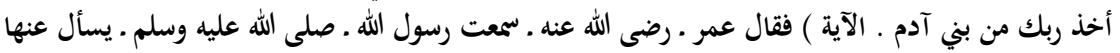

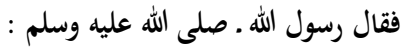

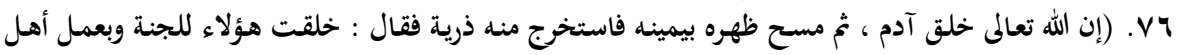

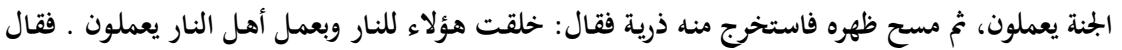

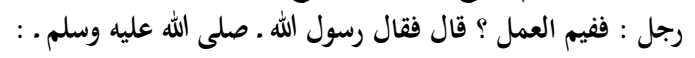

VV

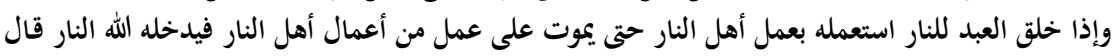




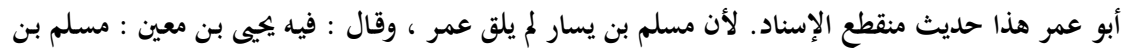

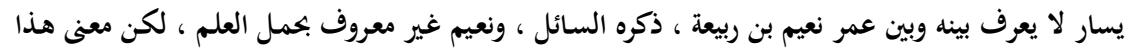

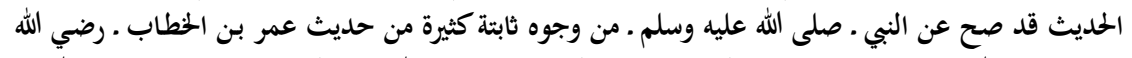

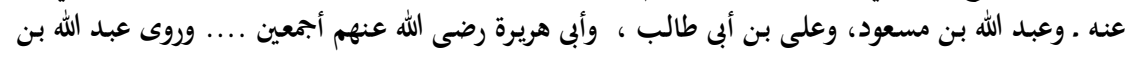

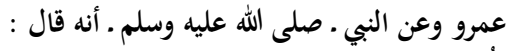

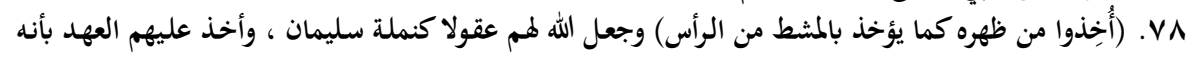

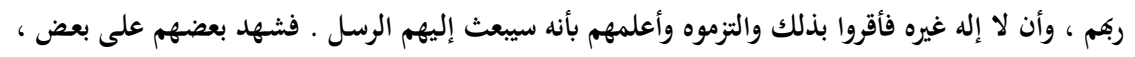

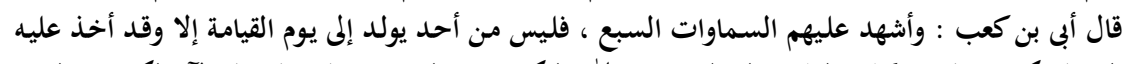

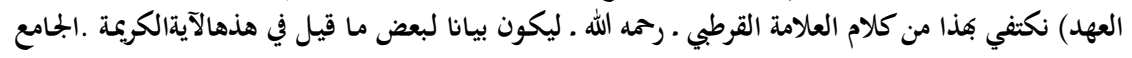

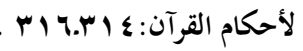

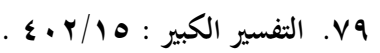

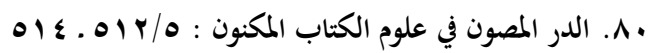

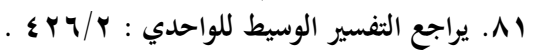

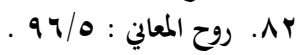

بـ

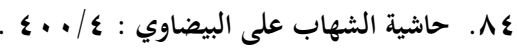

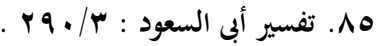

צ

AV

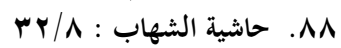

ه9.

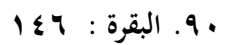

19.

ra

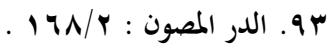

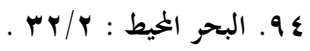

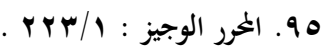

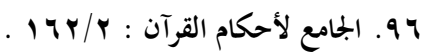

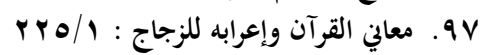

Q

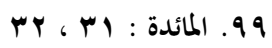

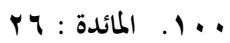

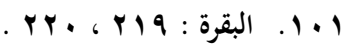

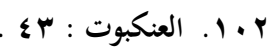

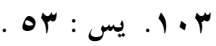

